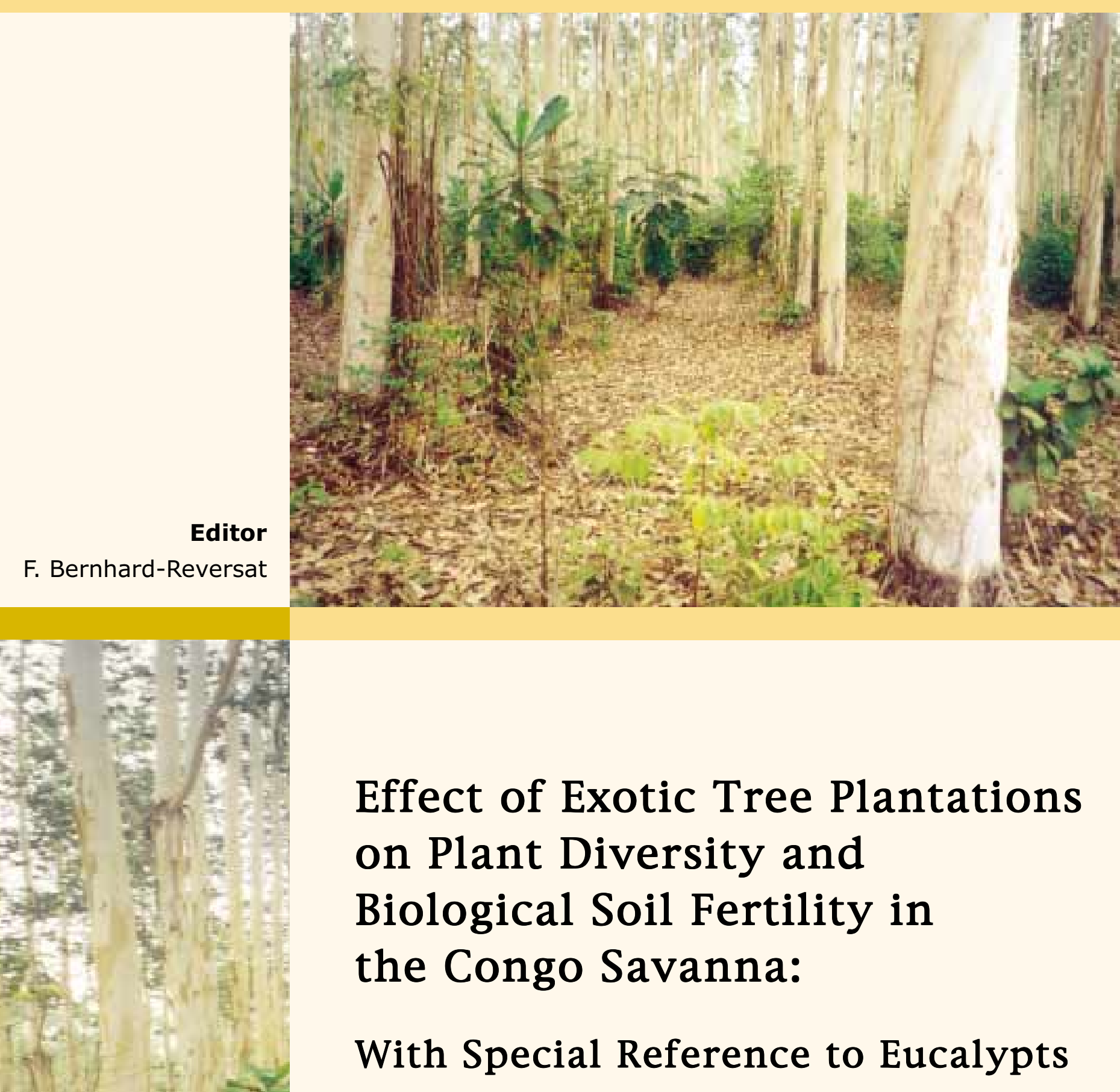




\title{
Effect of Exotic Tree Plantations on Plant Diversity and Biological Soil Fertility in the Congo Savanna: With Special Reference to Eucalypts
}

\author{
Editor
}

F. Bernhard-Reversat 
Cover and inside photos by C. Cossalter (July 2001)

Understorey development in a mature clonal plantation of Eucalyptus hybrid, Pointe-Noire, Congo.

(C) 2001 by Center for International Forestry Research

Published in December 2001

Printed by SMK Grafika Desa Putera, Indonesia

\section{ISBN 979-8764-72-2}

Bernhard-Reversat, F. (Editor) 2001. Effect of exotic tree plantations on plant diversity and biological soil fertility in the Congo savanna: with special reference to eucalypts. Center for International Forestry Research, Bogor, Indonesia, 71p.

\section{Published by}

Center for International Forestry Research

Mailing address: P.O. Box 6596 JKPWB, Jakarta 10065, Indonesia

Office address: JI. CIFOR, Situ Gede, Sindang Barang, Bogor Barat 16680, Indonesia

Tel.: +62 (251) 622622; Fax: +62 (251) 622100

E-mail: cifor@cgiar.org

Web site: http://www.cifor.cgiar.org 


\section{Table of Contents}

Introduction

General objectives and sites: J.P. Bouillet and F. Bernhard-Reversat

Part 1. Improvement of biodiversity in plantations

Chapter 1. Effect of exotic tree plantations and site management on plant diversity.

C. Huttel and J.J. Loumeto

Chapter 2. Effect of exotic tree plantations on vertebrate fauna.

A.Brosset

Part 2. Biological factors of fertility related to organic matter dynamics

Chapter 3. Litterfall, litter quality and decomposition changes

with eucalypt hybrids and plantation age.

F. Bernhard-Reversat, J.J. Loumeto and J.P. Laclau

Chapter 4. Soil fertility changes with eucalypt hybrids and plantation age: soil organic matter.

J.J. Loumeto and F. Bernhard-Reversat

Part 3. Biological factors of fertility related to the diversity and density of soil biota

Chapter 5. Asymbiotic nitrogen fixation

in savanna and eucalypt plantations.

J. Le Mer and P. A. Roger

Chapter 6. Effect of exotic tree plantations

on free living and plant parasitic soil nematodes and population

changes with eucalypt hybrids and plantation age.

P.M. Loubana and G. Reversat

Chapter 7. Effect of exotic tree plantations on invertebrate soil macrofauna and population changes with eucalypt hybrids and plantation age.

I.M. Mboukou-Kimbatsa and F. Bernhard-Reversat

\section{Conclusions}

Soil biological fertility undergoes fundamental changes

when fast growing exotic trees are planted on a poor savanna soil.

F. Bernhard-Reversat and C. Huttel

References 


\section{Acknowledgements}

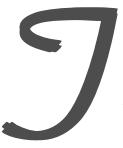

his report is the result of the collaboration of scientists from IRD (Institut de Recherche pour le Développement, previously ORSTOM, France), UR2PI (Unité de Recherche sur la Productivité des Plantations Industrielles, Congo), University of Brazzaville, DGRST, (Direction de la Recherche Scientifique, Congo), CIRAD (Centre de Coopération Internationale en Recherche Agronomique pour le Dévelopement), and MNHN (Museum National d'Histoire Naturelle, France).

Financial support for this research and its publication provided by the CIFOR/JAPAN Research Project 'Rehabilitation of Degraded Tropical Forest Ecosystems' and the involvement of Mr. C. Cossalter (CIFOR) in planning the projects are acknowledged. ECO S.A. and the Congolese Service National de Reboisement (S.N.R.) are acknowledged for welcoming the field work in their plantations. Directors of the Centre IRD of Pointe-Noire, Mr. A. Joseph and Mr. J. Geoffroy, are acknowledged for supplying field and laboratory facilities for the research team. Soil and plant nutrient analyses were carried out at the Analysis Laboratory of the Centre IRD of Pointe-Noire, under the direction of P. Esmard and L. Veysseyre. Technical assistance from Mrs. V. Teixeira and S. Sid Saya (IRD Bondy), Mr. M. Tsatsa and Mr. J.J. Kibondzi (IRD Pointe-Noire) is acknowledged.

The authors are greatly indebted to Dr. J.A. Parrotta (USDA Forest Service) and Dr. J.W. Turnbull for reviewing and improving the manuscript. We also thank Mr. C. Cossalter, Mr. G. Applegate, Dr. R. Nasi and Dr. T. Toma (CIFOR) for their valuable comments. 


\title{
Introduction
}

\section{General Objectives and Sites}

\author{
J.P. Bouillet ${ }^{1}$ and F. Bernhard-Reversat ${ }^{2}$
}

\section{Introduction}

$\mathrm{F}$

ast-growing tree plantations, mainly Eucalyptus spp., Pinus spp. and Acacia spp., are widespread in tropical countries. Among these species eucalypts are continuously being planted and planted areas have increased twofold every ten years since 1970, reaching 14 million hectares in 1997 (FAO 1982; Pandey 1997; Bouvet 1999). In 1977, eucalypts accounted for $18 \%$ of the forest plantation areas in tropical regions compared to $4 \%$ for pines and $7 \%$ for acacias (Pandey 1997). Their main use is for pulp production and eucalypt pulp production in the world increased from 22 to 31 million tons between 1979 and 1995 (Wilson et al. 1995).

\section{Environmental Impact of Fast-growing Tree Plantations in the Tropics}

This has been a controversial topic, some arguing that these species exhaust soil water and nutrient resources, and prevent understorey vegetation growth, thus resulting in decreased biodiversity and in further soil erosion and loss of fertility (Poore and Fries 1985; Abbasi and Vinithan 1997; Bouvet 1998). Several regional meetings (India, Thailand) have debated these issues, and an abundant literature has emerged from the 1991, 1995, 1997 meetings of the IUFRO 'Silviculture and breeding of eucalypts' group (IUFRO working party 2.08.03). The IUFRO work focussed on assessing the environmental impact of eucalypt plantation compared to other ecosystems, native or planted. Four main issues were considered.

The first issue, concerning biodiversity, was addressed during the Word Bank Biodiversity Rehabilitation project (Parrotta 1995b), which examined the hypothesis that tree plantation can catalyse biodiversity rehabilitation on degraded tropical lands (Parrotta et al. 1997) Mainly conducted on sites with degraded soils and vegetation, these studies found fast-growing tree plantations (eucalypts and other species) helped regeneration of undergrowth plants from surrounding forests, thus increasing their biodiversity and fertility (Geldenhuys 1997; Harrington and Ewel 1997). A few studies reported the similar results for animal populations (Brosset 1997; Mboukou-Kimbatsa et al. 1998).

The second issue, dealt with nutrient requirement and nutrient cycling. It was shown that nutrient requirements of eucalypt and pine stands were of the same order of magnitude and were generally higher than those of native ecosystems (Baker and Attiwill 1985; Poore and Fries 1985; Cortez 1996; Grove et al. 1996). However nutrient outputs resulting from harvest

\footnotetext{
1 UR2PI, B.P. 1120, Pointe-Noire, Congo.

2 Laboratoire d'Ecologie des Sols Tropicaux, Centre IRD d'Ile de France, 32 avenue Henri Varagnat, 93143 Bondy, France.
} 
varied greatly according to species, even among eucalypts (Morais et al. 1990; O’Connell and Grove 1996; Gonçalves et al. 1997; Sankaran et al. 2000), and according to harvest practices for the previous stand (Bouillet et al. 2000; Gonçalves et al. 1999; Laclau et al. 2000a). Nutrients needed for stand growth were provided primarily through nutrient cycling by litterfall and internal fluxes (Turner and Lambert 1983, 1996; Attiwill et al. 1996; Cortez 1996). These processes allowed a satisfactory tree growth on nutrient-poor soils.

The third issue dealt with changes in the physico-chemical properties of the soils. Comparisons were made between monospecific eucalypt stands with monospecific stands of other tree species (Bernard-Reversat 1987; Brent et al. 1996; Cortez 1996; Negi and Sharma 1996; Harmand 1998; Dambrine et al. 1999), mixed stands eucalypts and nitrogen fixing trees (Binkley 1997; Parrotta 1999) or the previous vegetation (Herbert 1996; Binkley and Resh 1999). The general trend in these studies was a decrease of soil $\mathrm{Ca}$ and $\mathrm{N}$ under eucalypt or pine monoculture. However the introduction of $\mathrm{N}$ fixing species improved $\mathrm{N}$ balance and tree growth.

The fourth issue concerned the water needs of eucalypt plantations. It was shown that water use efficiency depended on water availability (Kallarackal and Somen 1997; Chunyang 1999) and on genetic origin of the planted trees (Bond and Stock 1990; Dye 1996; Chunyang 1999). Hydrological studies carried out in South Africa showed a decrease in streamflows when tree plantations were grown in the watersheds, and this decrease was greater with eucalypt than with pine, although pines exhibit a lower water-use efficiency (Dye 1996; Scott and Smith 1997). Such results could guide the choice of the species to be grown.

\section{Background and General Objectives of the Study}

In the southern coastal region of Congo near Pointe-Noire, savanna covers large areas on very poor sandy soils, and only small areas close to human settlements are used for agricultural purposes. These savannas have been used since 1978 for plantations of fast-growing trees, mainly eucalypts, which are grown commercially. The common management practice is a first seven-year rotation established from rooted-cutting clones followed by a second and sometimes a third coppice rotation of the same duration. Experimental plantations of several fast-growing species, among which are eucalypts, Australian acacias and tropical pines, were also established in this area, and $100 \mathrm{~km}$ west of it, near Loudima in the Niari valley on clay soils (Fig. 0.1).

Figure 0.1 Map of the Republic of Congo showing the study sites

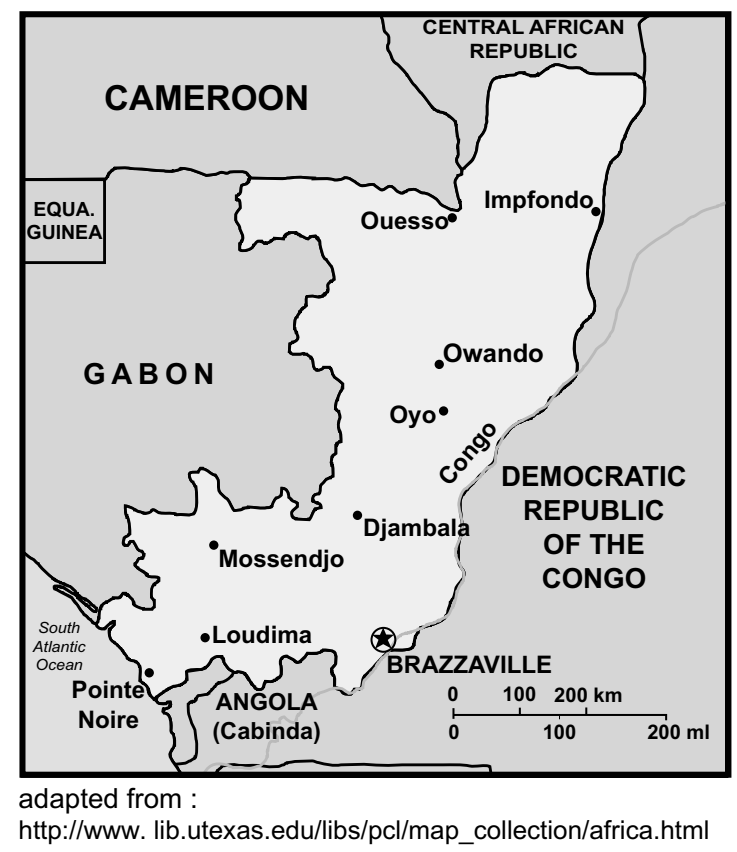

In the Congo, due to nutrient poor soils and low rainfall climate, sustainability is a priority area for scientific research on eucalypt production systems (Bouillet et al. 1997) and multidisciplinary studies focusing on this goal have been conducted since 1997 (Fig. 0.2). The first topic deals with biogeochemical cycles, for which nutrient balance studies are conducted in a first rotation eucalypt crop and in a native savanna (Laclau et al. $2000 \mathrm{~b}$, 2000c). The second topic is specially concerned with logging residue management, the objective of the CIFOR network 'Site Management and Productivity in Tropical Plantation Forests' (Bouillet et al. 2000). The third topic is the importance of the biological factors in fertility, which has received little attention in most management studies, and is the purpose of the present report. Although not being exhaustive, a 
Figure 0.2 Representation of the coordinated research programme on plantation sustainability in the Congo

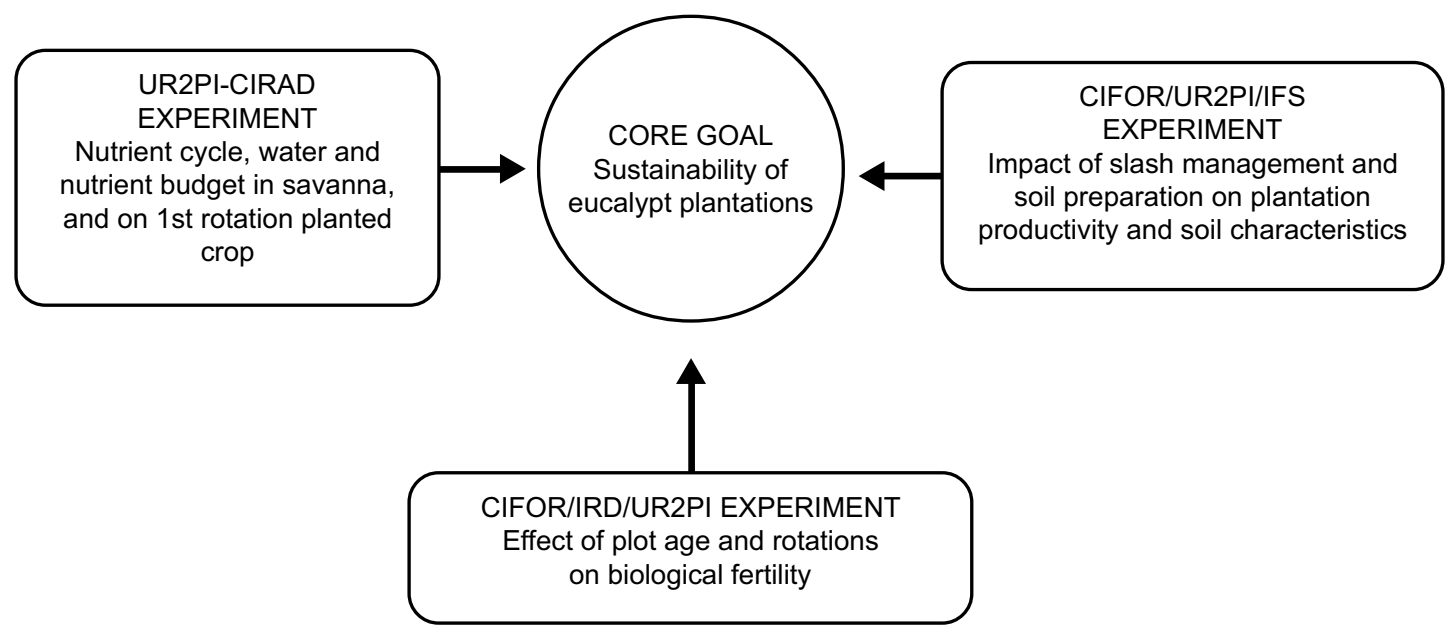

set of biotic processes was investigated in relation to plantation age and in particular the effect successive rotations on biotic changes was studied. The World Bank Biodiversity Rehabilitation project with CIFOR support gave an opportunity to study the development of native vegetation together with vertebrates and soil fauna within plantations. Following these studies, the CIFOR/ Japan project 'Rehabilitation of Degraded Tropical Ecosystems' supported a second phase to further investigate the biological factors of fertility.

Because plant biodiversity controls soil biota and is known to influence the whole trophic chain (Lamotte 1979; Lavelle et al. 1997), it is of tremendous importance in soil and ecosystem functioning (Schulze and Mooney 1993). A particular feature of the Congolese plantations was their establishment on savanna with poor soil and vegetation. Although young plantations of fastgrowing species (eucalypt, acacia and pine) exhibit sparse understorey vegetation, undergrowth starts invading plantations and building up thickets after about ten years. The effect of both savanna and forest on undergrowth colonisation, and the trends of understorey vegetation changes with age, received special attention (Part 1). The relationships between vegetation and fertility are closely linked to litter and soil organic matter quality and quantity; these were studied in an age series of eucalypt hybrids and clones (Part 2). The density of the main taxa of macrofauna and nematodes, which act either through organic matter decomposition, soil biogenic structures, and parasitism, was assessed according to the age of plantation and logging. Nitrogen fixation ability, related to the dramatic $\mathrm{N}$ shortage which is expected to occur in aging plantations, was also studied (Part 3).

\section{Location and Site Description}

The study areas were located near Pointe-Noire $\left(4^{\circ} 48^{\prime} \mathrm{S}, 11^{\circ} 54^{\prime} \mathrm{E}\right)$ and near Loudima ( $4^{\circ} 07^{\prime} \mathrm{S}$, $\left.13^{\circ} 51^{\prime} \mathrm{E}\right)$. At both sites, annual precipitation averages $1250 \mathrm{~mm}$, with four dry months from June to September and the mean annual temperature is $25^{\circ} \mathrm{C}$.

Soils are highly desaturated ferrallitic soils (French classification). According to the FAO/ UNESCO classification they are Ferralic Arenosols at Pointe-Noire and Xanthic ferralsols at Loudima. In Pointe-Noire, where most of the study was carried out, soils are sandy in texture (clay content less than 5\% in the top layer). They were developed from thick Plio-Pleistocene continental sandy deposits. Soils in this series vary from 80 to $300 \mathrm{~m}$ depth, and are underlaid by a dolomitic sandstone clay series from the Cretaceous period (Jamet 1975). They are particularly poor in nutrients and organic matter (the exchange capacity is 0.4 to $0.7 \mathrm{cmol} \mathrm{kg}^{-1}$ and the $\mathrm{C}$ content $0.7 \%$ in the $0-10 \mathrm{~cm}$ layer) (Table $0.1)$.

In Loudima the soils were developed on sediments (schisto-calcareous) from Precambrian 
Table 0.1 Main soil characteristics in the Pointe-Noire region (from Bouillet et al. 1999)

\begin{tabular}{|c|c|c|c|c|c|}
\hline Layer & A11 & A12 & B1 & B21 & B22 \\
\hline Depth & $0-5 \mathrm{~cm}$ & $5-50 \mathrm{~cm}$ & $50-70 \mathrm{~cm}$ & $70-280 \mathrm{~cm}$ & $280-600 \mathrm{~cm}$ \\
\hline Color & dark gray & light gray & yellow brown & yellow & ochre \\
\hline Texture & sandy & sandy & sandy & sandy & sandy to sandy clay \\
\hline Porosity & very porous & porous & porous & slightly porous & very slightly porous \\
\hline Compacity & light & slight compact & slight compact & compact & very compact \\
\hline Clay (\%) & 7.9 & 6.6 & 9.9 & 10.6 & 11.4 \\
\hline Silt (\%) & 2.1 & 2.1 & 2.2 & 2.4 & 2.7 \\
\hline Sand $(\%)$ & 90 & 91.3 & 87.9 & 87 & 85.9 \\
\hline $\mathrm{PH} \mathrm{H} 2 \mathrm{O}$ & 4.38 & 4.51 & 4.95 & 4.81 & 4.88 \\
\hline $\mathrm{PH} \mathrm{KCl}$ & 4 & 4.26 & 4.46 & 4.57 & 4.47 \\
\hline Total C (\%) & 0.85 & 0.47 & 0.23 & 0.1 & 0.05 \\
\hline Total N (\%) & 0.063 & 0.039 & 0.025 & 0.019 & 0.016 \\
\hline $\mathrm{C} / \mathrm{N}$ & 13.5 & 12.1 & 9.2 & 5.3 & 3.1 \\
\hline \multicolumn{6}{|l|}{ Exchange complex* } \\
\hline $\mathrm{Ca}$ (cmolc kg-1 soil) & 0.11 & 0.08 & 0.08 & 0.09 & 0.09 \\
\hline Mg (cmolc kg-1 soil) & 0.08 & 0.03 & 0.03 & 0.02 & 0.03 \\
\hline $\mathrm{K}$ (cmolc kg ${ }^{-1}$ soil $)$ & 0.03 & 0.02 & 0.01 & 0.01 & 0.02 \\
\hline $\mathrm{Na}$ (cmolc kg-1 soil) & 0.04 & 0.01 & 0 & 0.01 & 0.01 \\
\hline Sum (cmolc kg-1 soil) & 0.26 & 0.14 & 0.12 & 0.14 & 0.15 \\
\hline CEC (cmolc kg-1 soil) & 0.53 & 0.29 & 0.31 & 0.28 & 0.34 \\
\hline Sum/CEC (\%) & 49.1 & 48.3 & 38.7 & 50 & 44.1 \\
\hline
\end{tabular}

* determined by cobaltihexamine extraction, ICP determination of cations, Sum: exchangeable cations sum, CEC: cation exchange capacity.

rocks (de Boissezon 1967). They are richer than in Pointe-Noire area with clay content from $40 \%$ in surface layers to $70 \%$ in the deepest layers, and their depth is around $3 \mathrm{~m}$ (Nzila 1992).

Soil differences result in floristic and biomass differences in native vegetation: on sandy soils the savanna vegetation is dominated by Loudetia sp., and on clay soils, by the more productive Hyparrhenia sp. Chromolaena odorata is also more common on clay soil. Very few trees or shrubs grow on these savannas which are not extensively used by people. Cattle rearing is restricted to a few ranches and therefore neither grazing nor fodder collection are common. Agriculture is undeveloped and only a few fields of cassava or peanuts are grown around the villages; people cultivate instead in secondary forests. However inhabitants and hunters set fire to the savanna annually.

In Pointe-Noire, the study site is located on undulating hills, at an elevation of 40-180 m. In Loudima the site is located in the plain of the Niari river, at an elevation of 110-180 $\mathrm{m}$. The distance between the study sites and the natural secondary forest ranges from 0 to $3 \mathrm{~km}$ in Pointe-Noire, and is greater in Loudima.

\section{Plantation Forestry in Coastal Congo}

Intensive forestry research and experimental plantations were carried out in Congo by C.T.F.T. (now Centre International de Recherches Agronomiques pour le Développement, CIRADForêt) from 1950 and led to the improvement of genetic status and multiplication techniques of Eucalyptus (Delwaulle and Laplace 1988). Savanna soils near Pointe-Noire were then planted with eucalypts by U.A.I.C (Unité d'Afforestation Industrielle du Congo, now replaced by Eucalyptus du Congo, Société Anonyme/ECO S.A.), a society mainly owned by the Congolese state. Nowadays, exploitation of eucalypts is intensive and logs are exported for pulp industry. Industrial and experimental plantations at Pointe-Noire cover ca. 40000 ha and experimental plantations at Loudima cover several hundreds of hectares.

The main species investigated in the present study is Eucalyptus PF1, a natural hybrid between E. alba and undetermined parents with predominance of E. urophylla and E. grandis (Delwaulle 1989). Investigations were also carried out in a plantation of an artificial hybrid, $E$. urophylla $\mathrm{x}$ E. grandis which will over time replace the natural hybrid. The other trees studied were 
Acacia auriculiformis, for which only small experimental plots were available, and Pinus caribaea, for which commercial plantations are available on small areas (1000 ha in the PointeNoire region and 1500 ha in Loudima).The mean size of 7-year-old Eucalyptus (age of harvest) when growing well is $28 \mathrm{~m}$ in height, $14-16 \mathrm{~cm}$ in diameter at breast height, $16 \mathrm{~m}^{2} \mathrm{ha}^{-1}$ in basal area. This gives an average stand volume of approximately $175 \mathrm{~m}^{3}$ per hectare. Total biomass is approximately 100-120 $\mathrm{tha}^{-1}$ in both acacia and eucalypts at 7 years of age (Loumeto 1986, Bernhard-Reversat et al. 1993).

Trees were planted after tillage to a depth of $20 \mathrm{~cm}$ and fertilisation in the plantation hole (150 $\mathrm{g} \mathrm{tree}^{-1}$ NPK 13-13-21). There was no subsequent fertilisation. Manual or mechanical weeding took place for two or three years after planting. Trees were planted at various spacings, with a trend toward closer spacing, ranging from $5.0 \times 5.0 \mathrm{~m}$ to $3.5 \times 3.5 \mathrm{~m}$. There was no thinning.
Trees were clear-felled and harvested when plantations were 7 years old, except in plots preserved for experimental purposes. One to two sprouts were then allowed to coppice from the stumps in order to establish a new plantation. The stands were fertilised (200 kg ha-1 NPK 13-13-21) between 1 and 2 years old and harvested when 5 to 7 years old. Fires in the plantations are accidental but occur at an increasing rate, and now affect $8-17 \%$ of plantations, depending on the area.

\section{The Studied Plots}

During the first project (World Bank Biodiversity Rehabilitation project), first rotation stands were chosen for study, mainly in the experimental plantations. In the Pointe-Noire region (sandy soils) the studies were conducted in an age series of PF1 eucalypt and in plots chosen to evaluate the effect of tree spacing, distance to forest, herbicide and fire on understorey regeneration and

Table 0.2 Characteristics of plots in first project

\begin{tabular}{|c|c|c|c|c|}
\hline Code* & Species & $\begin{array}{l}\text { Age } \\
(\mathrm{yr})\end{array}$ & Type $^{* *}$ & Treatment \\
\hline \multicolumn{5}{|c|}{ Kouilou Region (Pointe-Noire) on sandy soil } \\
\hline Ea & Eucalyptus PF 1 & 6 & $E$ & Age series \\
\hline $\mathrm{Eb}$ & & 11 & $\mathrm{E}$ & Age series \\
\hline Ec & & 13 & $\mathrm{E}$ & Age series \\
\hline Ed & & 16 & $\mathrm{E}$ & Age series \\
\hline $\mathrm{Ee}$ & & 18 & $\mathrm{E}$ & Age series \\
\hline Ef & & 20 & $\mathrm{E}$ & Age series \\
\hline $\mathrm{Eg}$ & & 15 & $\mathrm{E}$ & Spacing $4.8 \times 5.4 \mathrm{~m}$ \\
\hline Eh & & 15 & $\mathrm{E}$ & Spacing $2.5 \times 2.8 \mathrm{~m}$ \\
\hline $\mathrm{Ei}$ & & 13 & $\bar{C}$ & Distance to forest $10 \mathrm{~m}$ \\
\hline $\mathrm{Ej}$ & & 13 & C & Distance to forest $50-100 \mathrm{~m}$ \\
\hline Ek & & 12 & C & Control no herbicide or fire \\
\hline $\mathrm{El}$ & & 12 & c & Herbicide applied 1 year before \\
\hline Em & & 12 & C & Herbicide applied 3 months before \\
\hline En & & 12 & $\mathrm{C}$ & Fires in Nov. 1993 and Nov. 1994 \\
\hline Eo & & 12 & $\mathrm{C}$ & Fire in Nov. 1993 \\
\hline A & Acacia auriculiformis & 16 & $\mathrm{E}$ & \\
\hline$P$ & Pinus caribaea & 15 & C & \\
\hline $\mathrm{Sa}$ & Savanna & & & Native vegetation \\
\hline $\mathrm{F}$ & Secondary forest & & & Native vegetation \\
\hline \multicolumn{5}{|c|}{ Niari Region (Loudima) on clay soil } \\
\hline $\mathrm{EL}$ & Eucalyptus PF 1 & 26 & E & \\
\hline $\mathrm{AL}, \mathrm{A}$ & Acacia auriculiformis & 12 & $\mathrm{E}$ & \\
\hline $\mathrm{PL}$ & Pinus caribaea & 26 & $\mathrm{E}$ & \\
\hline SL & Savanna & & & Native vegetation \\
\hline
\end{tabular}

${ }^{*}$ Codes identify plots in this report. ${ }^{* *} \mathrm{E}=$ experimental plot, $\mathrm{C}=$ commercial plot. 
biodiversity. Studies were also conducted on one plot of each of $A$. auriculiformis and $P$. caribaea. In the Loudima region (clay soils) one plot of each species, Eucalyptus PF1, A. auriculiformis, and $P$. caribaea, was studied (Table 0.2)

The second project (Biological Fertility Project) involved detailed studies of vegetation, litterfall and decomposition, soil organic matter, Nitrogen asymbiotic fixation, vertebrate fauna (mainly birds), nematodes and soil microfauna.
Research sites were chosen in the commercial eucalypt plantations of ECO S.A. near PointeNoire. These included an age series of Eucalyptus PF1 comprised of first rotation stands and coppice stands, two of which were just clear-felled, and by one first rotation plot of E.urophylla $x E$. grandis (Table 0.3). One multiclonal plot of $E$. urophylla $x$ E. grandis and one multiclonal plot of $E$. PF1 were used for clone comparisons. Most studies were carried out in a subset (Table 0.4).

Table 0.3 Characteristics of plots in second project in Pointe-Noire region

\begin{tabular}{|c|c|c|c|c|c|c|c|}
\hline & Hybrid & Clone & $\begin{array}{c}\text { Plot } \\
\text { age (yr) }\end{array}$ & $\begin{array}{c}\text { Tree } \\
\text { age (yr) }\end{array}$ & $\begin{array}{c}\text { Plantation } \\
\text { type* }^{*}\end{array}$ & $\begin{array}{c}\text { Present } \\
\text { state }^{* *}\end{array}$ & $\begin{array}{c}\text { Previous } \\
\text { exploitation }\end{array}$ \\
\hline Ep & E.PF 1 & $1-41$ & 6 & 6 & $1 \mathrm{R}$ & no & 0 \\
\hline $\mathrm{Eq}$ & & & 6 & 0 & $1 \mathrm{R}$ & $\mathrm{CF}$ & 0 \\
\hline $\mathrm{Er}$ & & & 13 & 6 & Coppice & no & 1 \\
\hline Es & & & 14 & 0 & Coppice & $\mathrm{CF}$ & 1 \\
\hline Et & & & 19 & 7 & Coppice & no & 2 \\
\hline $\mathrm{Eu}$ & & & 19 & 19 & $1 \mathrm{R}$ & no & 0 \\
\hline Ev & $\begin{array}{l}\text { E. PF1 and } \\
\text { urograndis }\end{array}$ & various & 8 & 8 & $1 \mathrm{R}$ & no & 0 \\
\hline $\begin{array}{l}\text { Ew } \\
\mathrm{Sb}\end{array}$ & E. PF 1 & various & 5 & 6 & $\begin{array}{c}1 \mathrm{R} \\
\text { Savanna }\end{array}$ & $\begin{array}{l}\text { no } \\
\text { no }\end{array}$ & 0 \\
\hline
\end{tabular}

${ }^{*} 1 \mathrm{R}=$ first rotation, ${ }^{* *} \mathrm{CF}=$ clear felled.

Figure 0.3 Mean annual precipitation and temperature at Pointe-Noire (1990-1996)

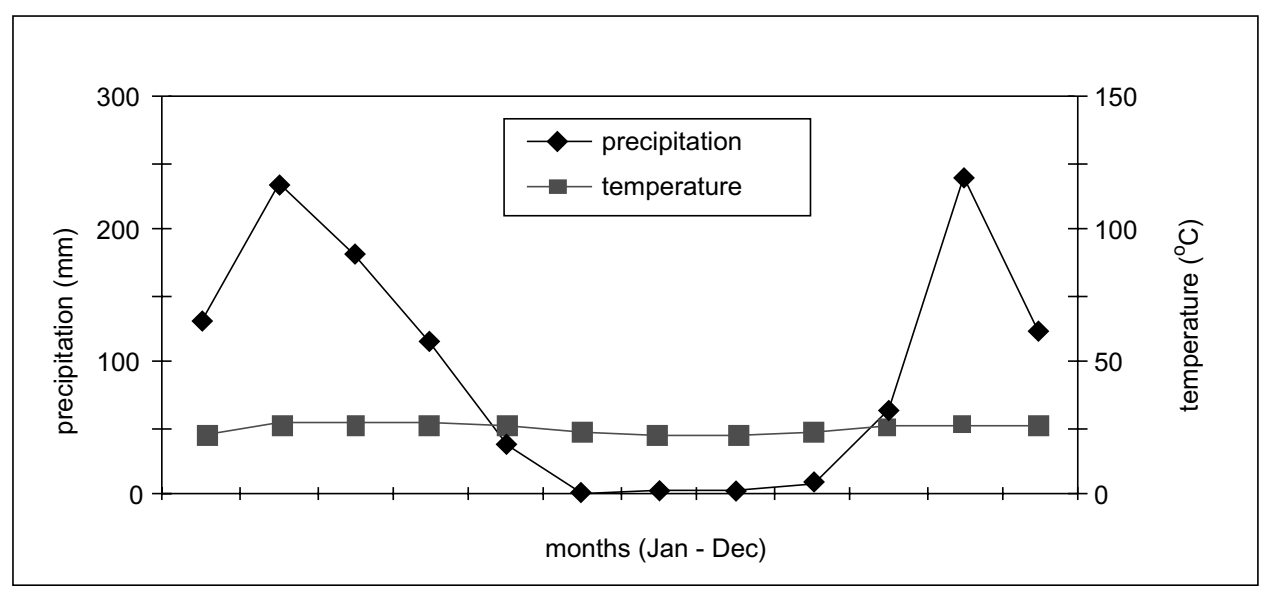


Table 0.4 Plots used for studies of vegetation, litterfall and decomposition, soil organic matter, asymbiotic nitrogen fixation, vertebrate fauna (birds), nematodes and soil macrofauna

\begin{tabular}{|c|c|c|c|c|c|c|c|}
\hline Code & Vegetation & Litter & $\begin{array}{c}\text { Soil organic } \\
\text { matter }\end{array}$ & $\begin{array}{c}\mathrm{N}- \\
\text { fixation }\end{array}$ & Birds & Nematodes & $\begin{array}{c}\text { Soil } \\
\text { macrofauna }\end{array}$ \\
\hline $\mathrm{Ea}$ & + & & & & + & + & + \\
\hline Eb & + & & & & + & & \\
\hline Ec & + & & & & + & & \\
\hline Ed & + & & & & + & + & \\
\hline $\mathrm{Ee}$ & + & & & & & + & \\
\hline Ef & + & & & & + & + & + \\
\hline $\mathrm{Eg} / \mathrm{Eh}$ & + & & & & & & + \\
\hline $\mathrm{Ei} / \mathrm{Ej}$ & + & & & & + & & \\
\hline Ek & + & & & & & + & \\
\hline El & + & & & & & & \\
\hline $\mathrm{Em}$ & + & & & & & + & + \\
\hline En & + & & & & & + & \\
\hline Eo & + & & & & & & \\
\hline A & + & & & & + & + & + \\
\hline$P$ & + & & & & + & & + \\
\hline EL & + & & & & & + & + \\
\hline$A L$ & + & & & & & + & \\
\hline PL & + & & & & & + & + \\
\hline $\mathrm{Ep}$ & & + & + & + & & + & + \\
\hline $\mathrm{Eq}$ & & & + & & & & + \\
\hline $\mathrm{Er}$ & & + & + & + & & + & + \\
\hline Es & & & + & & & & + \\
\hline Et & & + & + & + & & + & + \\
\hline Eu & & + & + & + & & + & + \\
\hline Ev & & + & + & + & & + & + \\
\hline Ew & & & & & & & + \\
\hline $\mathrm{F}$ & & & & & & & + \\
\hline $\mathrm{Sa}$ & & & + & + & & + & + \\
\hline SL & & & & & & + & + \\
\hline
\end{tabular}


Part 1

Improvement of Biodiversity in Plantations 


\title{
Chapter 1.
}

\section{Effect of Exotic Tree Plantations and Site Management on Plant Diversity}

\author{
C. Huttel ${ }^{1}$ and J.L. Loumeto ${ }^{2}$
}

\section{Introduction}

น

he ability of plantations to improve biodiversity must be taken into account by foresters when they have to address the problem of plantation sustainability, especially in a poor environment like that of the Congolese eucalypt plantations. Species' richness under natural eucalypt forests can vary considerably and diversified understoreys are well-known (Kirkpatrick 1997). The catalytic effect of forest plantations on the regeneration of biodiversity and the possibility of restoration of degraded lands has been documented (Parrotta 1993, 1995; Silva Junior et al. 1995; Lamb 1998; Parrotta and Knowles 1999) and is relevant to the 'Eucalyptus controversy' where criticism related to biodiversity issues has prevailed over a long period (IFS 1989; Calder et al. 1992; see also the introduction to this report). Although most exotic tree plantations are established for wood production, and forest vegetation reconstitution is only a secondary and often undesirable effect, a less obvious component of biodiversity, that of soil organisms, might benefit from plant diversity and improve soil quality.

Studies on understorey vegetation in eucalypt plantations have been reported by Basanta et al. 1989; Madeira et al. 1989; Lugo et al. 1990; Parrotta 1995a; Silva et al. 1995; and Michelsen et al. 1996. Some data are available on the understorey vegetation of Congolese eucalypt plantation (Nongamani 1988; Soler 1994). Loumeto and Huttel reported in 1997 preliminary observations within the framework of a multi-site study which involved several countries (Parrota 1995b). This study adopted a common survey methodology for vegetation studies in order to obtain comparable results. In the present study, species richness, species behaviour and stand parameters were analysed under fast-growing tree plantations and compared with the characteristics of nearby secondary forest patches.

\section{Study Sites and Methods}

The general characteristics of the study plots are given above in the 'General objectives and sites' (Table 0.2) and also in Loumeto and Huttel (1997). The investigated planted species were mainly a eucalypt hybrid (PF1), and secondarily Acacia auriculiformis and Pinus caribaea. Surveys were more intensive on the sandy site near Pointe-Noire, due to easier accessibility and because more plantations were grown there than on the clay soil site near Loudima, which was added in order to assess the effect of soil. In both places, the original savanna was also investigated, and a secondary forest plot was surveyed at Pointe-Noire site. Most observations were carried out in experimental unexploited plantations, but some observations in commercial plantations allowed evaluation of the effects of logging, fire or herbicide application (cf.

1 Le Caillou, Valojoux, 24290 Montignac, France.

2 Laboratoire de Biologie Végétale, Université de Brazzaville, BP 69, Brazzaville, Congo. 
Figure 1.1 Undergrowth heterogeneity in eucalypt production plots

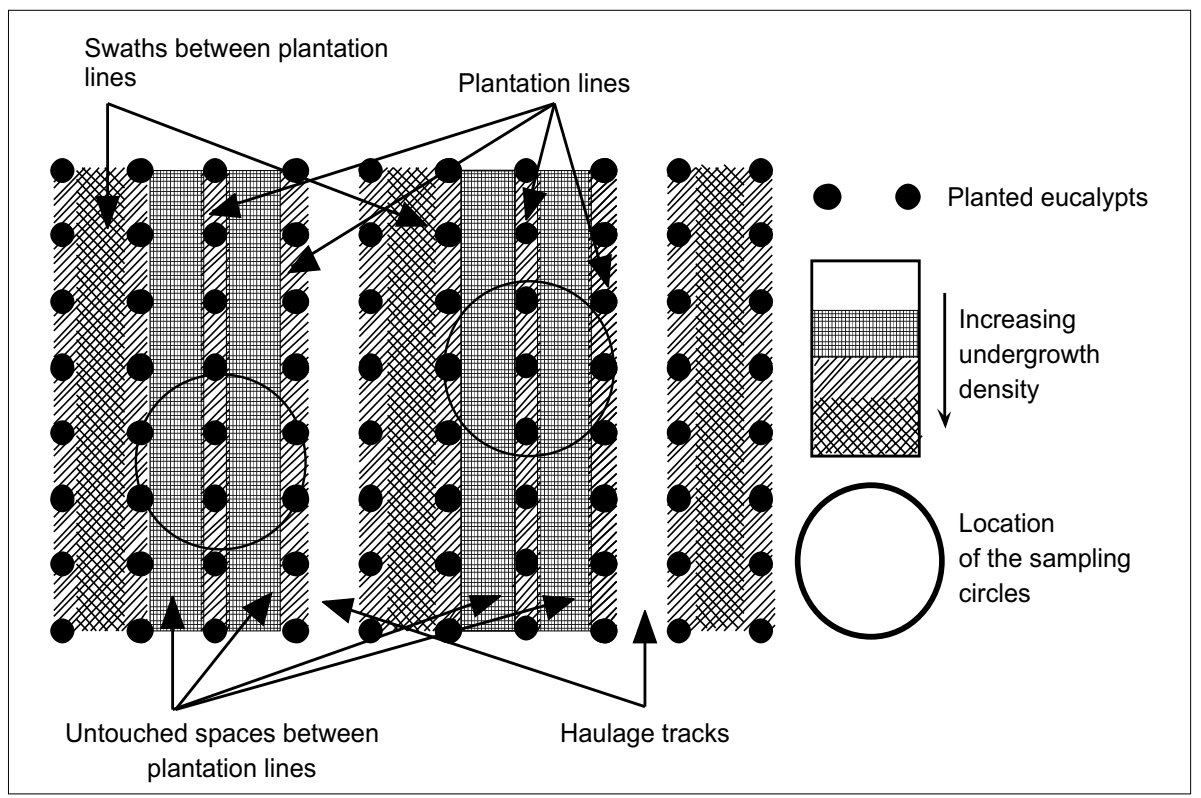

the introduction and Table 0.2.). These disturbed plots were chosen with similar age and history, first planted in 1983 or 1984 and logged in 1990 or 1991. Therefore all selected commercial plots were coppice with trees from 5 to 6.5 years old. The sampling method took into account the level of heterogeneity within each type of plots. In commercial plots, survey circles were located exclusively on plantation lines where undergrowth had grown undisturbed. In doing so, the survey avoided areas where undergrowth was depleted by vehicle traffic and areas showing excessive growth due to increased nutrient supplies through decomposing material in swaths. Plants were counted according to height classes $(0-30 \mathrm{~cm}, 30$ $200 \mathrm{~cm}$ and over $200 \mathrm{~cm}$ height) in concentric circles of 1,2 and $5 \mathrm{~m}$ radius respectively. The number of replicates in each plot (from 4 to 11) was chosen to fit with vegetation heterogeneity. The height and diameter at breast height (dbh) of woody plants, if relevant, were measured, whereas the presence and cover percentages of herbaceous species, mainly Poaceae and Cyperaceae, were estimated. Planted tree characteristics, density, height and dbh, were also measured.

The plants listed in the undergrowth were separated in two main groups, the planted timber trees and the native species. The second group was divided according to their usual habitat (forest or savanna), or usual behaviour for ruderal species common in disturbed habitats such as roadsides or burned areas. Further in the text, the expressions 'preference groups' and 'preferring species' will refer to the most usual habitat of the species.

\section{Results and Discussion}

\section{Heterogeneity in production plots}

Undergrowth was relatively homogeneous in experimental undisturbed plots. In commercial plots, silvicultural practices added further spatial heterogeneity to the effects of other parameters. During the two first years of plantation growth, undergrowth was weeded using a cover-crop between plantation lines, and manually within the lines when necessary. So undergrowth was generally more developed on the plantation lines than between them (Fig. 1.1).

Eucalypts are clear fallen and harvested when 7 years old. When logs are taken out the remaining wood is collected for charcoal or fuelwood, and the residues, eucalypt and undergrowth leaves and twigs are stacked in swath lines. The general pattern of these disturbances and their effects on undergrowth distribution (Fig. 1.1) showed regular alternating areas of dense and high woody undergrowth in the swath interlines, mainly 
Figure 1.2 Number of species obseved in the different plots of tree plantations and natural stands

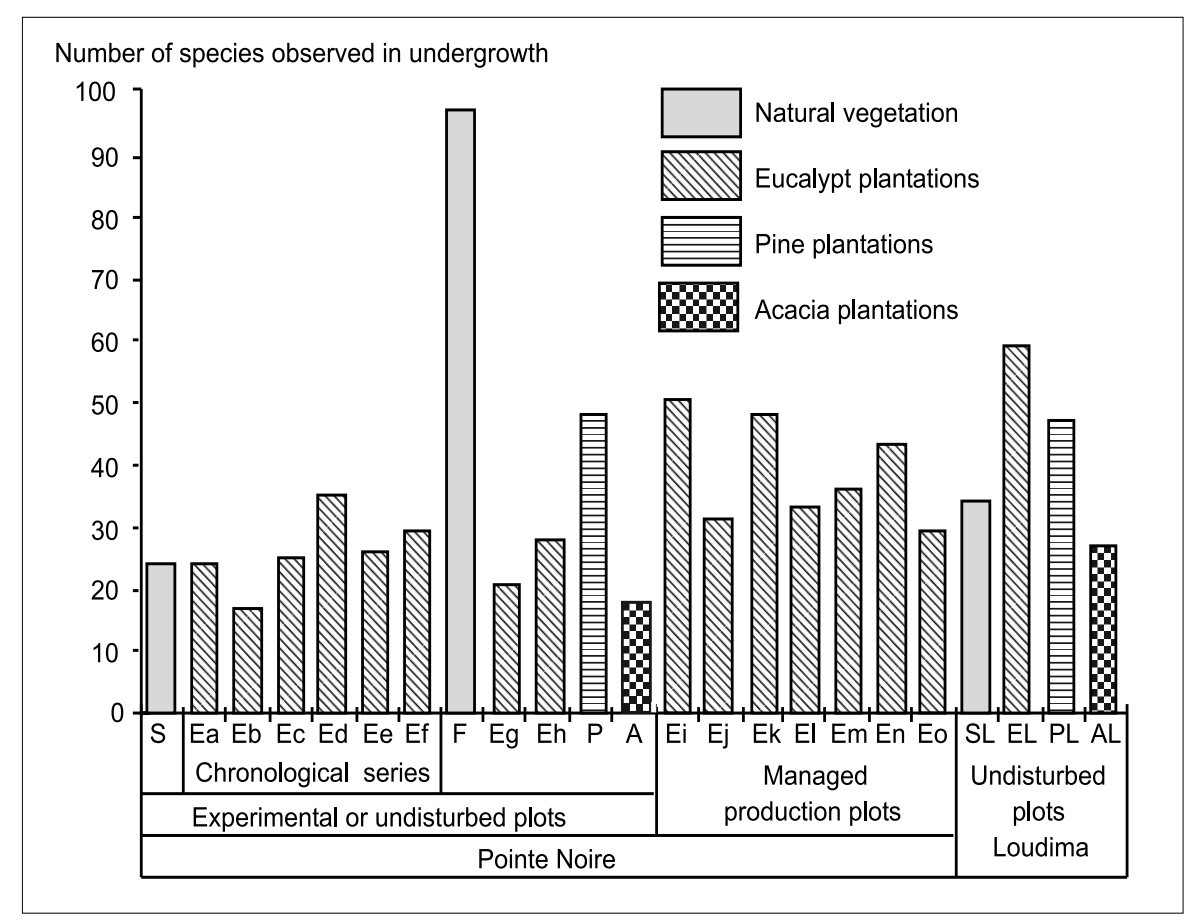

See Tables 0.2 and 0.3 for plot descriptions.

herbaceous cover on the haulage tracks, and strips of undisturbed undergrowth on the lines.

\section{Number of species}

Total number of species of undergrowth was relatively low under exotic tree plantations as compared to secondary forest (Fig. 1.2). In the chronological series, species number ranged from 24 to values always under 30 , whereas the understorey vegetation in the secondary forest, investigated with the same method, held nearly 100 different species. The relatively high species richness in the undergrowth of the eucalypt plantation at Loudima could be due to its older age (26 years) but also to site differences, particularly soil conditions. The species composition of the savanna was also richer at Loudima than at Pointe-Noire.

Disturbed commercial eucalypt plantations had slightly greater species richness than undisturbed experimental plantations ( mean $=38.6$ versus 25.6 in undisturbed plots). Fire occurrences or herbicide application reduced the number of species compared to control plot (Ek without fire or herbicide). Higher plantation density (in plot Eh) increased the species richness of undergrowth (28 species in the dense part versus 21 in the more open plot Eg). Forest proximity also increased the number of species: 50 species in the closest part, $\mathrm{Ei}$, and only 32 in $\mathrm{Ej}$ located far from the forest edge.

Comparing stands of the same age, pine plantations had higher undergrowth diversity, and Acacia the least. Undergrowth in pine plantations, especially in the Pointe-Noire region, had a very irregular pattern with dense vegetation patches in gaps due to tree death, and large undergrowth-free areas with bare litter.

\section{Floristic similarities between natural vegetation and undergrowth}

In the Pointe-Noire plots, including savanna and forest, 215 species were identified, 142 of which were found only in plantations, and 128 only under Eucalyptus. The percentages of species found together in plantations, savanna and forest plots, 
Figure 1.3 Percentages of species shared with savanna, forest or exclusive of plantation undergrowth

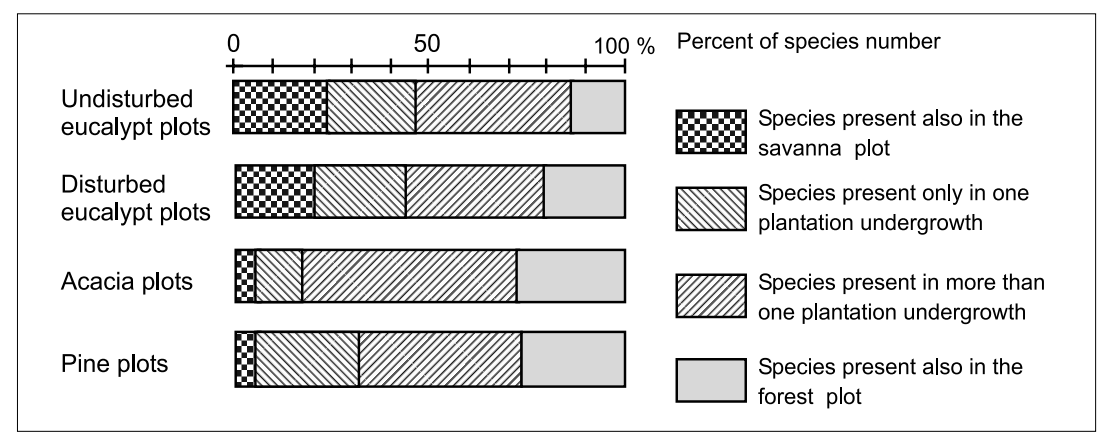

or found only in plantations for each kind of plantation was calculated (Fig.1.3).

Species found exclusively in plantations made the largest species' group ranging from 59 to $67 \%$ of the total number of species. An important proportion of species was found only in one plantation type, including mainly Anthocleista schwenfurtii in undisturbed eucalypt plantations and Maprounea africana in the disturbed ones. There were no outstandingly frequent species in pine and acacia undergrowth. Taking into account the species present in more than one kind of plantation, the highest similarity was found between undisturbed and disturbed eucalypt plantations, and the most frequent among these species were three Clerodendron spp., Bartiera nigritiana, Macaranga monandra or Psorospermum tenuifolium. Species found only under plantation belonged mainly to the forestpreferring group (over 60\%), and 25\% were ruderal species.

The percentage of species found in both savanna and plantations varied inversely with the percentage of species found in both forest and plantations. The first were savanna species (Asystasia gangetica or Annona arenaria) and also ruderal species (Scleria boivinii, Hypoxis of angustifolia). The second were exclusively forestpreferring species and the most frequent were the erect shrub Chaetocarpus africanus, the climbing shrub Premna lucens and the shrub-like forest edge species Psychotria cf peduncularis.

The savanna and forest plots contained some species that were not found under plantations. Only two species, Loudetia arundinacea and Vernonia potamophylla, were exclusively present in the savanna plot. Most savanna plot species were found under eucalypt plantations ( 19 from 24 were present in undisturbed eucalypt plots and 21 in disturbed plots). This number was much reduced under the other tree species: one species (the ruderal Scleria boivinii) under acacia and three species under pine.

The pattern was different for the species found in the forest plots, and 71 out of 96 were never found outside the forest. Some of these species had high frequencies in the forest plot, among which were emergent tree species like Carapa procera or Hymenocardia ulmoides, although most were shrub-like or woody understorey species: Microdesmis puberula, Cola sp.1, Rhabdophyllum welwitschii, Cnestis urens, or the strictly forest vine Gnetum africanum. Numerous species (41) were found at low frequency (only in one survey circle).

Disturbed eucalypt plantation plots shared 21 species with the forest plot, 11 with undisturbed plots, 13 in pine plantation and 5 in acacia plantation. Three forest-preferring shrubs species were present in all types of plantation and in the forest plot, Chaetocarpus africanus, Psychotria $\mathrm{cf}$ peduncularis and Premna lucens. Two forest pioneers, Alchornea cordifolia and Macaranga spinosa are frequent in the forest and eucalypt plantations but absent under pine or acacia; two more species were found only in forest and eucalypt undergrowth, Anthocleista schwenfurtii in undisturbed plantations and Maprounea africana in commercial areas. There were no especially frequent species shared with the forest in pine or acacia undergrowth. 
Figure 1.4 Undergrowth species distribution in preference groups (percent of total number of species in planted and natural stands)

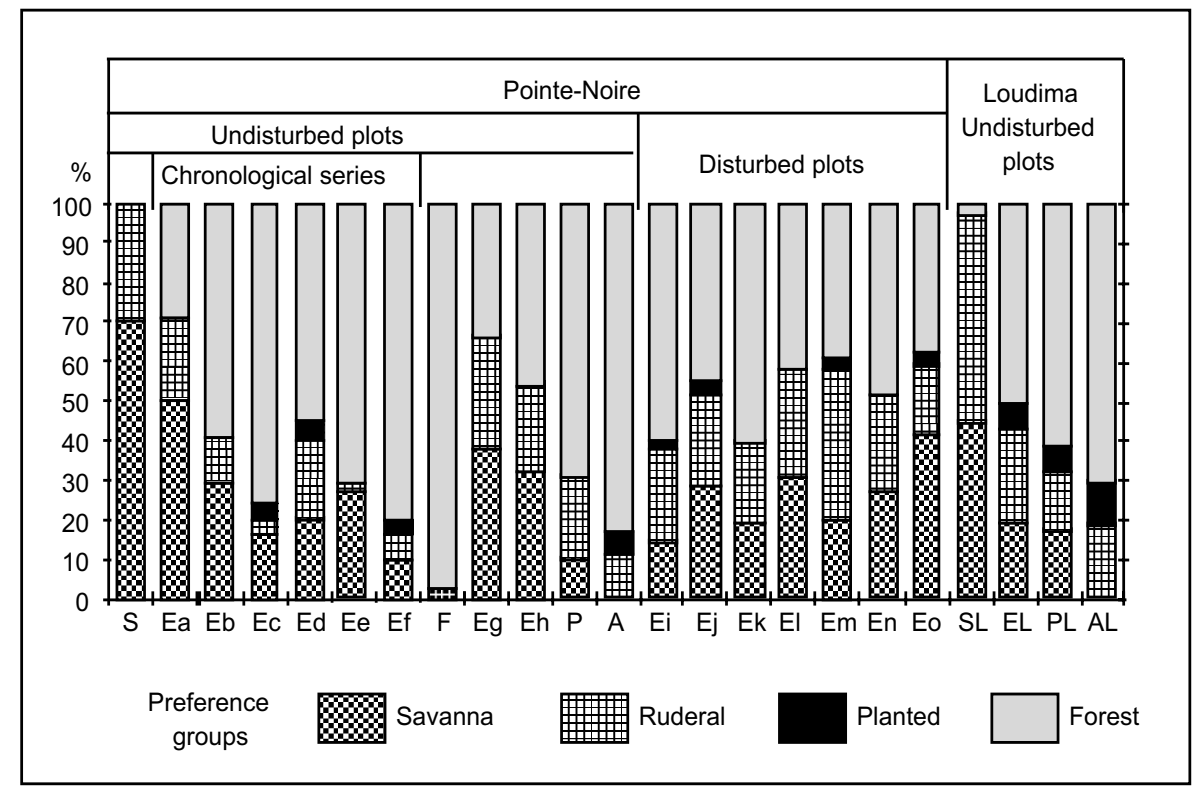

See Tables 0.2 and 0.3 for plot descriptions.

\section{Distribution in preference groups}

The percentages of savanna, ruderal, and forest species are illustrated in Fig. 1.4, where naturally occurring young trees of the planted species are referred to as "planted". The most significant development occurred in the chronological series (left part of Fig. 1.4). The proportion of forest species increased from $0 \%$ to nearly $80 \%$ during the first 20 years after eucalypt planting. During the same time, the percentage of ruderal species decreased, and that of savanna species decreased even more drastically.

Undergrowth in the managed commercial eucalypt plantations was richer in ruderal species than the experimental undisturbed plantations ( $24.9 \%$ versus $14.7 \%)$. The mean percentage of forest species was approximately $48 \%$ in these 12 year-old plots, the value that would be expected for an 8-year-old undisturbed plantation. The percentage of savanna species was $26 \%$, like in a 10-12-year-old experimental plot. Compared with the control plot (Ek plot in Figs. 1.2 and 1.3), the undergrowth of the herbicide (glyphosate)applications plots and plots which had experienced fires had similar responses to disturbances: decrease of the proportion of forest-preferring species and increase of savanna and/or ruderal species. The proximity of natural forest edge (plots $\mathrm{Ei}$, forest at $10 \mathrm{~m}$, and $\mathrm{Ej}$, forest at $50-100 \mathrm{~m}$ ) led to a significant increase of the number of forest species and decrease in the number of savanna species.

In both Pointe-Noire and Loudima sites, Acacia plantations were free from savanna species. Under Acacia, the proportion of ruderal species was also lower than under Eucalyptus or under Pinus. Acacia auriculiformis was more favourable to the regeneration of forest species than the eucalypt and pine.

\section{Outstanding species}

Changes in floristic composition with time can be detected in the chronological series.

Table 1.1 takes into account the species present in at least two different plots. Many savanna species disappeared during the first years after eucalypt plantation (see also Fig. 1.4): the two grasses Asystasia gangetica and Hyparrhenia diplandra were not found in the chronological series; others species like Cyperus amabilis, 
Table 1.1 Occurrence frequencies (number of replicates holding the species devided by the total number of circles) of plan species in savanna, forest and eucalypt chronological series at Pointe-Noire

\begin{tabular}{|c|c|c|c|c|c|c|c|c|c|c|}
\hline Species & Family & Pref. ${ }^{1}$ & Sav. $^{2}$ & $\begin{array}{c}\mathrm{Ea} \\
6 \mathrm{yr}\end{array}$ & $\begin{array}{c}E b \\
11 \mathrm{yr}\end{array}$ & $\begin{array}{c}\text { Ec } \\
13 \mathrm{yr}\end{array}$ & $\begin{array}{c}E d \\
16 \mathrm{yr}\end{array}$ & $\begin{array}{c}\mathrm{Ee} \\
18 \mathrm{yr}\end{array}$ & $\begin{array}{c}\text { Ef } \\
20 \mathrm{yr}\end{array}$ & For. $^{2}$ \\
\hline $\begin{array}{l}\text { Cyperus amabilis } \\
\text { Cyanotis alba } \\
\text { Cassia mimosoides } \\
\text { Kyllingia erecta } \\
\text { Cyperus esculentus }\end{array}$ & $\begin{array}{l}\text { Cyperaceae } \\
\text { Commelinaceae } \\
\text { Caesalpiniaceae } \\
\text { Cyperaceae } \\
\text { Cyperaceae }\end{array}$ & $\begin{array}{l}S \\
S \\
S \\
S \\
R\end{array}$ & $\begin{array}{l}0.4 \\
0.4 \\
0.3 \\
0.2 \\
0.2\end{array}$ & $\begin{array}{l}0.2 \\
0.4 \\
0.1 \\
0.1 \\
0.1\end{array}$ & & & & & & \\
\hline $\begin{array}{l}\text { Smilax kraussiana } \\
\text { Hypoxis cf angustifolia } \\
\text { Psorospermum febrifugum } \\
\text { Zornia sp. } \\
\text { Bulbostylis laniceps }\end{array}$ & $\begin{array}{l}\text { Smilacaceae } \\
\text { Hypoxidaceae } \\
\text { Hypericaceae } \\
\text { Fabaceae } \\
\text { Cyperaceae }\end{array}$ & $\begin{array}{l}\mathrm{S} \\
\mathrm{R} \\
\mathrm{S} \\
\mathrm{R} \\
\mathrm{S}\end{array}$ & $\begin{array}{l}0.2 \\
0.1 \\
0.2 \\
0.1 \\
0.4\end{array}$ & 0.2 & 0.1 & $\begin{array}{l}0.1 \\
0.1 \\
0.4\end{array}$ & $\begin{array}{l}0.2 \\
0.1\end{array}$ & & & \\
\hline $\begin{array}{l}\text { Cyperus tenax } \\
\text { Andropogon gabonensis } \\
\text { Elionurus argenteus } \\
\text { Ctenium newtonii } \\
\text { Loudetia arundinacea }\end{array}$ & $\begin{array}{l}\text { Cyperaceae } \\
\text { Poaceae } \\
\text { Poaceae } \\
\text { Poaceae } \\
\text { Poaceae }\end{array}$ & $\begin{array}{l}\mathrm{S} \\
\mathrm{S} \\
\mathrm{S} \\
\mathrm{S} \\
\mathrm{S}\end{array}$ & $\begin{array}{l}0.3 \\
0.2 \\
0.4 \\
0.4 \\
0.4\end{array}$ & $\begin{array}{l}0.1 \\
0.4\end{array}$ & 0.2 & 0.3 & 0.1 & $\begin{array}{l}0.3 \\
0.1 \\
0.1 \\
0.6\end{array}$ & & \\
\hline $\begin{array}{l}\text { Annona arenaria } \\
\text { Eriosema erici-rosenii } \\
\text { Scleria boivinii } \\
\text { Landolphia sp. } \\
\text { Anthocleista nobilis }\end{array}$ & $\begin{array}{l}\text { Annonaceae } \\
\text { Fabaceae } \\
\text { Cyperaceae } \\
\text { Apocynaceae } \\
\text { Loganiaceae } \\
\end{array}$ & $\begin{array}{l}S \\
S \\
R \\
F \\
F\end{array}$ & $\begin{array}{l}0.2 \\
0.1 \\
0.3\end{array}$ & $\begin{array}{l}0.3 \\
0.4 \\
0.2 \\
0.1 \\
0.1\end{array}$ & $\begin{array}{l}0.1 \\
0.5\end{array}$ & $\begin{array}{l}0.3 \\
0.4 \\
0.1 \\
0.3\end{array}$ & $\begin{array}{l}0.4 \\
0.5 \\
0.1 \\
0.4 \\
\end{array}$ & $\begin{array}{l}0.4 \\
0.3\end{array}$ & $\begin{array}{l}0.7 \\
0.2\end{array}$ & 0.2 \\
\hline $\begin{array}{l}\text { Alchornea cordifolia } \\
\text { Rhynchelytrum repens } \\
\text { Elaeis guineensis } \\
\text { Barteria nigritiana } \\
\text { Macaranga monandra }\end{array}$ & $\begin{array}{l}\text { Euphorbiaceae } \\
\text { Poaceae } \\
\text { Arecaceae } \\
\text { Passifloraceae } \\
\text { Euphorbiaceae }\end{array}$ & $\begin{array}{l}\mathrm{F} \\
\mathrm{S} \\
\mathrm{F} \\
\mathrm{F} \\
\mathrm{F}\end{array}$ & & $\begin{array}{l}0.1 \\
0.1 \\
0.1 \\
0.2 \\
0.2\end{array}$ & $\begin{array}{l}0.5 \\
0.1\end{array}$ & $\begin{array}{l}0.4 \\
0.3\end{array}$ & $\begin{array}{l}0.4 \\
0.1\end{array}$ & $\begin{array}{l}0.6 \\
0.3 \\
0.3 \\
0.6\end{array}$ & $\begin{array}{l}0.5 \\
0.2 \\
0.2 \\
0.7 \\
0.2\end{array}$ & \\
\hline $\begin{array}{l}\text { Cogniauxia podolaena } \\
\text { Caloncoba welwitchii } \\
\text { Uvaria brazzavillensis } \\
\text { Macaranga spinosa } \\
\text { Premna lucens }\end{array}$ & $\begin{array}{l}\text { Cucurbitaceae } \\
\text { Flacourtiaceae } \\
\text { Annonaceae } \\
\text { Euphorbiaceae } \\
\text { Verbenaceae } \\
\end{array}$ & $\begin{array}{l}\mathrm{R} \\
\mathrm{F} \\
\mathrm{F} \\
\mathrm{F} \\
\mathrm{F}\end{array}$ & & $\begin{array}{l}0.1 \\
0.1\end{array}$ & $\begin{array}{l}0.1 \\
0.1 \\
0.4 \\
0.2\end{array}$ & $\begin{array}{l}0.5 \\
0.5\end{array}$ & $\begin{array}{l}0.1 \\
0.5\end{array}$ & $\begin{array}{l}0.1 \\
0.6 \\
0.6\end{array}$ & $\begin{array}{l}0.2 \\
0.2 \\
0.7\end{array}$ & $\begin{array}{l}0.2 \\
0.7\end{array}$ \\
\hline $\begin{array}{l}\text { Psychotria cf peduncularis } \\
\text { Bertiera cf batesii } \\
\text { Eucalyptus PF1 } \\
\text { Chrysobalanus icaco } \\
\text { Chaetocarpus africanus }\end{array}$ & $\begin{array}{l}\text { Rubiaceae } \\
\text { Rubiaceae } \\
\text { Myrtaceae } \\
\text { Chrysobalanaceae } \\
\text { Euphorbiaceae } \\
\end{array}$ & $\begin{array}{l}F \\
F \\
P \\
F \\
F\end{array}$ & & & $\begin{array}{l}0.3 \\
0.4\end{array}$ & $\begin{array}{l}0.5 \\
0.4 \\
0.1 \\
0.3 \\
0.1\end{array}$ & $\begin{array}{l}0.5 \\
0.4\end{array}$ & $\begin{array}{l}0.6 \\
0.6 \\
0.3 \\
0.3 \\
\end{array}$ & $\begin{array}{l}0.7 \\
0.7 \\
0.2 \\
0.2 \\
0.2\end{array}$ & $\begin{array}{l}0.3 \\
0.2\end{array}$ \\
\hline $\begin{array}{l}\text { Rauwolfia vomitoria } \\
\text { indet. } \\
\text { Anthocleista schwenfurtii } \\
\text { Barteria fistulosa } \\
\text { Desmodium cf mauritianum } \\
\text { Psorospermum tenuifolium } \\
\text { Otomeria guineensis } \\
\text { Canthium sp. } \\
\text { Clerodendron sp.1 } \\
\text { Leptactina manii } \\
\text { Maprounea membranacea }\end{array}$ & $\begin{array}{l}\text { Apocynaceae } \\
\text { Asclepiadaceae } \\
\text { Loganiaceae } \\
\text { Passifloraceae } \\
\text { Fabaceae } \\
\text { Hypericaceae } \\
\text { Rubiaceae } \\
\text { Rubiaceae } \\
\text { Verbenaceae } \\
\text { Rubiaceae } \\
\text { Euphorbiaceae }\end{array}$ & $\begin{array}{l}F \\
F \\
F \\
F \\
R \\
F \\
R \\
F \\
F \\
F \\
F\end{array}$ & & & & 0.1 & $\begin{array}{l}0.1 \\
0.1 \\
0.1 \\
0.1 \\
0.3 \\
0.5 \\
0.3 \\
0.5\end{array}$ & $\begin{array}{l}0.1 \\
0.3 \\
0.4 \\
0.1 \\
\\
0.6 \\
0.3 \\
0.3 \\
0.3 \\
0.4\end{array}$ & $\begin{array}{l}0.2 \\
0.7 \\
0.2 \\
0.2 \\
0.2 \\
0.2 \\
0.2\end{array}$ & 0.5 \\
\hline \multicolumn{11}{|c|}{$\begin{array}{l}\text { Additional species were found only in one site: } \\
-6 \text { species present only in savanna plot } \\
-24 \text { species present only in one plot of the chrononogical series } \\
-86 \text { species present only in the forest plot }\end{array}$} \\
\hline
\end{tabular}

${ }^{1}$ Pref. : preferred habitat, S. : savanna, F. : forest, R. : ruderal

2 Sav. : savanna, For. : forest, see Tables 0.2 and 0.3 for codes. 
Table 1.2 Occurrence frequencies (number of repetitions with the species devided by the total number of circle) of species in diturbed commercial eucalypt plantations

\begin{tabular}{|c|c|c|c|c|c|c|c|c|c|}
\hline Species & Family & Pref. & Ek & El & $\mathrm{Em}$ & En & Eo & $\mathrm{Ei}$ & $\mathrm{Ej}$ \\
\hline Annona arenaria & Annonaceae & $S$ & 0.4 & 0.4 & 0.4 & 0.6 & 0.5 & 0.4 & 0.4 \\
\hline Anthocleista nobilis & Loganiaceae & $\mathrm{F}$ & 0.3 & 0.6 & 0.4 & 0.6 & 0.1 & 0.6 & 0.6 \\
\hline Barteria nigritiana & Passifloraceae & $\mathrm{F}$ & 0.3 & 0.4 & 0.4 & 0.4 & 0.4 & 0.8 & 0.6 \\
\hline Bulbostylis laniceps & Cyperaceae & S & 0.4 & 0.1 & 0.4 & 0.6 & 0.5 & 0.6 & 0.6 \\
\hline Cyperus amabilis & Cyperaceae & S & 0.1 & 0.3 & 0.1 & 0.3 & 0.1 & 0.2 & 0.3 \\
\hline Elionurus argenteus & Poaceae & $S$ & 0.2 & 0.1 & 0.3 & 0.3 & 0.5 & 0.8 & 0.4 \\
\hline Loudetia arundinacea & Poaceae & S & 0.4 & 0.6 & 0.6 & 0.4 & 0.4 & 0.6 & 0.6 \\
\hline Oldenlandia affinis & Rubiaceae & $\mathrm{R}$ & 0.4 & 0.3 & 0.4 & 0.1 & 0.5 & 0.6 & 0.3 \\
\hline Alchornea cordifolia & Euphorbiaceae & $\mathrm{F}$ & 0.3 & 0.1 & 0.4 & & 0.2 & 0.8 & 0.4 \\
\hline Dissotis cf rotundifolia & Melastomataceae & $\mathrm{R}$ & 0.1 & 0.1 & 0.1 & & 0.1 & 0.6 & 0.1 \\
\hline Macaranga monandra & Euphorbiaceae & $\mathrm{F}$ & 0.1 & 0.1 & 0.3 & & 0.1 & 0.4 & 0.1 \\
\hline Premna lucens & Verbenaceae & $\mathrm{F}$ & 0.4 & & 0.6 & 0.4 & 0.5 & 0.8 & 0.3 \\
\hline Psorospermum febrifugum & Hypericaceae & S & 0.4 & 0.1 & 0.3 & 0.1 & 0.2 & & 0.4 \\
\hline Asystasia gangetica & Acabthaceae & S & 0.1 & 0.3 & 0.1 & & 0.1 & 0.4 & \\
\hline Bertiera of batesii & Rubiaceae & $\mathrm{F}$ & 0.4 & 0.4 & 0.4 & & 0.2 & 0.6 & \\
\hline Chromolaena odorata & Asteraceae & $\mathrm{R}$ & 0.1 & 0.1 & 0.6 & & & 0.2 & 0.1 \\
\hline Chrysobalanus icaco & Chrysobalanaceae & $\mathrm{F}$ & 0.1 & 0.1 & 0.1 & & & 0.4 & 0.1 \\
\hline Cyperus esculentus & Cyperaceae & $\mathrm{R}$ & & 0.3 & 0.4 & 0.1 & 0.5 & & 0.3 \\
\hline Hypoxis cf angustifolia & Hypoxidaceae & $\mathrm{R}$ & 0.3 & & 0.1 & 0.3 & & 0.6 & 0.6 \\
\hline Maprounea membranacea & Euphorbiaceae & $\mathrm{F}$ & 0.2 & 0.1 & 0.1 & 0.1 & & & 0.3 \\
\hline Panicum brevifolium & Poaceae & $\mathrm{R}$ & & 0.1 & & 0.1 & 0.1 & 0.4 & 0.1 \\
\hline Rhynchelytrum repens & Poaceae & s & & 0.1 & & 0.3 & 0.3 & 0.8 & 0.1 \\
\hline Andropogon gabonensis & Poaceae & $\mathrm{s}$ & 0.1 & & & 0.1 & 0.4 & & 0.1 \\
\hline Chaetocarpus africanus & Euphorbiaceae & $\mathrm{F}$ & 0.1 & & 0.3 & & 0.3 & & 0.3 \\
\hline Desmodium cf mauritianum & Fabaceae & $\mathrm{R}$ & 0.2 & 0.3 & & & 0.1 & 0.4 & \\
\hline Eucalyptus PF1 & Myrtaceae & $P$ & & 0.1 & & 0.1 & & 0.2 & 0.1 \\
\hline Macaranga spinosa & Euphorbiaceae & $\mathrm{F}$ & 0.3 & & 0.6 & 0.3 & & 0.4 & \\
\hline Maprounea africana & Euphorbiaceae & $\mathrm{F}$ & 0.1 & & & & 0.1 & 0.8 & 0.1 \\
\hline Panicum cogoense & Poaceae & $\mathrm{S}$ & 0.1 & & & 0.1 & 0.2 & & 0.4 \\
\hline Smilax kraussiana & Smilacaceae & $\mathrm{s}$ & 0.2 & 0.3 & 0.3 & 0.1 & & & \\
\hline Vernonia brazzavillensis & Asteraceae & $\mathrm{F}$ & 0.3 & & & 0.3 & & 0.2 & 0.1 \\
\hline Adenia cissampeloides & Passifloraceae & $\mathrm{F}$ & 0.1 & & & & & 0.4 & 0.1 \\
\hline indet. & Asclepiadaceae & $\mathrm{F}$ & 0.1 & & & & 0.1 & 0.2 & \\
\hline Cogniauxia podolaena & Cucurbitaceae & $\mathrm{R}$ & & & & & 0.3 & 0.2 & 0.3 \\
\hline Elaeis guineensis & Arecaceae & $\mathrm{F}$ & & 0.1 & 0.1 & 0.1 & & & \\
\hline Eriosema erici-rosenii & Fabaceae & $\mathrm{S}$ & 0.1 & & 0.4 & 0.6 & & & \\
\hline Landolphia sp & Apocynaceae & $\mathrm{F}$ & 0.1 & 0.1 & & & & 0.2 & \\
\hline Psychotria cf peduncularis & Rubiaceae & $\mathrm{F}$ & 0.1 & & & 0.1 & 0.1 & & \\
\hline Scleria boivinii & Cyperaceae & $\mathrm{R}$ & 0.3 & 0.1 & & & & 0.6 & \\
\hline & \multirow{3}{*}{\multicolumn{9}{|c|}{$\begin{array}{l}\text { Additional species were found only in few sites: } \\
-15 \text { species present only in one plot } \\
-18 \text { species present only in two plots }\end{array}$}} \\
\hline & & & & & & & & & \\
\hline & & & & & & & & & \\
\hline
\end{tabular}

Pref.: as in Table 1.1 Ek: control without fire or herbicide, El-Em: herbicide application 1 year or 3 months ago; En-Eo: two or one fire occurence; Ei-Ej: plot at $10 \mathrm{~m}$ or 50-100 m from forest edge. 
Table 1.3 Structure parameters of tree crop and undergrowth vegetation in plantation and natural stands. (see Tables 0.2 and 0.3 for the complete definition of plots)

\begin{tabular}{|l|l|r|r|r|r|r|r|r|r|}
\hline \multirow{2}{*}{ Codes } & \multicolumn{2}{|c|}{ Treatment } & \multicolumn{2}{|c|}{ Density (a) } & \multicolumn{2}{c|}{ Soil Cov. (b) } & \multicolumn{2}{c|}{ Height (c) } & \multicolumn{2}{c|}{ Basal area (d) } \\
\cline { 3 - 11 } & & planted & und. (e) & herbac. & woody & planted & und.(e) & planted & und.(e) \\
\hline Sa & Savanna & - & 0 & 5 & 2 & - & 0 & - & 0 \\
Ea & E. PF1 6-yr-old & 6.2 & 8.0 & 2 & 1 & 23.8 & 1.8 & 13.0 & 0 \\
Eb & E. PF1 11-yr-old & 5.7 & 11.7 & 1 & 2 & 24.6 & 6.2 & 12.8 & 0.1 \\
Ec & E. PF1 13-yr-old & 5.3 & 28.5 & 1 & 3 & 28.9 & 9.2 & 13.7 & 0.5 \\
Ed & E. PF1 16 yr-old & 7.8 & 59.0 & 1 & 4 & 23.6 & 19.0 & 15.8 & 1.3 \\
\hline Ee & E. PF1 18-yr-old & 5.5 & 162.9 & 2 & 4 & 23.9 & 19.0 & 9.4 & 2.5 \\
Ef & E. PF1 20-yr-old & 7.2 & 106.0 & + & 5 & 28.2 & 12.8 & 20.2 & 0.8 \\
F & Secondary forest & - & 177.8 & + & 5 & - & 17.5 & - & 14.1 \\
Eg & E. PF1 low density & 3.8 & 33.1 & 2 & 3 & 26.8 & 3.4 & 8.9 & 0.1 \\
Eh & E. PF1 high density & 10.8 & 39.4 & 3 & 3 & 23.4 & 3.7 & 16.1 & 0.1 \\
\hline Ei & E. PF1 10 m from forest & 8.2 & 50.3 & 2 & 3 & 23.5 & 4.6 & 15.4 & 0.1 \\
Ej & E. PF1 50-100 m from forest & 6.7 & 25.4 & 2 & 3 & 21.9 & 2.7 & 11.8 & e \\
Ek & E. PF1 without herbicide or fire & 8.4 & 24.1 & 4 & 3 & 19.9 & 3.7 & 11.3 & 0.2 \\
El & E. PF1 herbicide 1 year ago & 7.5 & 80.2 & 3 & 2 & 22.2 & 4.3 & 9.6 & 0.2 \\
Em & E. PF1 herbicide 3 months ago & 9.6 & 12.3 & 3 & 3 & 21.6 & 5.9 & 14.6 & 0.1 \\
\hline En & E. PF1 two fire occurrences & 7.5 & 21.2 & 4 & 2 & 18.9 & 2.7 & 10.0 & 0 \\
Eo & E. PF1 one fire occurrence & 5.6 & 12.8 & 4 & 3 & 21.4 & 4.5 & 8.5 & 0.1 \\
A & acacia plantation & 9.3 & 374.3 & 1 & 5 & 14.3 & 5.7 & 14.1 & 0.3 \\
P & pine plantation & 7.5 & 37.5 & 2 & 3 & 22.1 & 4.4 & 34.5 & e \\
\hline SL & savanna (Loudima) & - & 4.9 & 5 & 2 & - & 4.8 & - & 1.4 \\
EL & eucalypt (Loudima) & 14.0 & 91.1 & 2 & 4 & 25.1 & 22.6 & 28.5 & 4.5 \\
AL & acacia (Loudima) & 7.2 & 0 & 1 & 5 & 16.4 & 0 & 10.0 & $\circ$ \\
PL & pine (Loudima) & 10.2 & 118.2 & 2 & 4 & 26.1 & 15.9 & 48.5 & 3.2 \\
\hline
\end{tabular}

a: number of woody plants over $30 \mathrm{~cm}$ high in $100 \mathrm{~m}^{2}$

b: soil cover according to the Braun-Blanquet scale

c: in metres, mean height for planted trees, maximum values for undergrowth

: missing data

e: value $<0.1$

Cyanotis lanata or Kylingia erecta were present only in the first stages of plantation growth. On the other hand, some savanna species persisted even in older stands, among which were Loudetia arundinacea and the savanna characteristic shrub, Annona arenaria.

Forest species invaded the undergrowth in successive waves. The trees Barteria nigritiana and Anthocleista nobilis, and the shrub Alchornea cordifolia were representative of the first forest pioneers. A second wave, colonising the 10-yearold plantations, comprised mainly shrubs, erect species like Bartiera cf batesii, Psychotria cf peduncularis or climbing species like Premna lucens. The last wave in the 20 years chronological series comprised shrubs like Canthium sp, Maprounea membranacea and Psorospermum tenuifolium.
In the disturbed commercial plantations (Table 1.2), some savanna species were present in most plots. Besides those which persisted in the undisturbed experimental plots of the age series mentioned above, the most frequent savanna species were herbs like Bulbostylis laniceps, Elyonurus argenteus, Psorospermum febrifugum. The sedge Cyperus amabilis, which disappeared rapidly in the chronological series, was present in all the disturbed plots, while Cyanotis lanata was present only in two plots.

The ruderal species were numerous in the commercial plantation plots. The most frequent included mainly forbs, like Oldenlandia affinis or Dissotis cf rotundifolia. It was noticeable that the weed Chromolaena odorata was more widely spread in commercial plantations than in the undisturbed experimental plots. 
The most frequent forest species present in commercial plantations were trees, Anthocleista nobilis, Barteria nigritiana, or erect shrubs, Alchornea cordifolia, Bertiera cf batesii, Macaranga monandra, Maprounea membranacea, or the climbing shrub Premna lucens. Undergrowth in commercial plantations included few species of the last invading wave, which was observed in experimental undisturbed plots: only Maprounea membranacea was found with noticeable frequency.

\section{Plot ordination}

A factorial correspondence analysis (FCA) of the surveyed plots at Pointe-Noire, taking into account the presence/absence of species in undergrowth (Fig. 1.5) and including both Pointe-Noire and Loudima plots, resulted in a strong separation between the two sites, and a lack of discrimination among Pointe-Noire plots; consequently the later were analysed separately. The species present in at least two plots were used for FCA calculations to reduce the excessive weight of very uncommon species. The points representing the plots are distributed within a triangle whose vertices are savanna, forest and acacia plantation. Axis 1 can be assumed to represent the increasing frequency of woody species or forest-preferring species. The disturbed plantations were close to each other and situated between the 6 and 10-year-old undisturbed plantation; the undergrowth of the forest proximity plot (Ei) and the control plot without herbicide or fire (Ek) were the most advanced towards forest regeneration. The undisturbed eucalypt plots (chronological series and spacing tests from Ea to Eh) showed a classification according to plot age and showed a trend to floristic similarity with the acacia plantation. The pine plantation was situated in an intermediate place. The points located close to savanna point corresponded to very disturbed situations (recent herbicide application or two fire occurrences, Em and En).

When the FCA was drawn with species coordinates instead of plot ordinates, the results led to similar conclusions. The FCA computations made with Loudima plots (not shown here) confirmed the different undergrowth in acacia plantations, the similarity of eucalypt undergrowth with savanna floristic list, and the pine plot position close to eucalypt plots. The similarity of plot respective positions in Pointe-Noire and Loudima could help the interpretation of axis 2 , and suggested that axis 2 represented an effect of exotic timber plantation introducing a floristic pattern, different from native vegetation.

Figure 1.5 Ordination of the planted and natural stands at Pointe-Noire

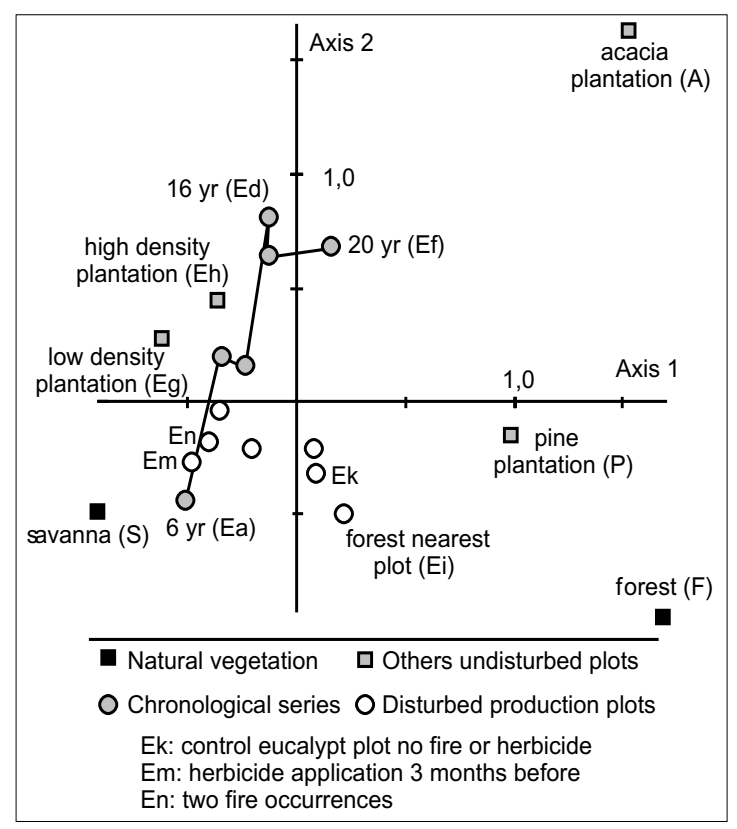

\section{Woody undergrowth parameters}

The density of woody plants in undergrowth increased with age in the chronological series (Table 1.3). Two woody forest-preferring species, Psychotria cf peduncularis and Psorospermum tenuifolium had particularly high densities. In the commercial eucalypt plantations (5 to 6.5 years), woody undergrowth density was approximately the same than that of undisturbed 11/13-year-old plantations Undergrowth density in the 15-yearold pine plantation was comparable to that of eucalypt plantations of the same age, whereas the 16-year-old acacia plantation showed a higher density value, $80 \%$ of which resulted from only two forest species, Psychotria cf peduncularis and Tarenna soyauxii.

Undergrowth plant height increased with stand age in undisturbed plots. Plantation management in commercial plantations, including undergrowth control practices, reduced the height of spontaneous vegetation to approximately that of the undergrowth of an 8-year-old undisturbed plot. 
Heights of undergrowth under pine and acacia were lower than in undisturbed eucalypt plantations of similar age, and were also low in the Loudima plots.

The basal area of undergrowth was low. In the chronological series, undergrowth basal area varied from 0 to $10 \%$ of total basal area, although a higher percentage of $21 \%$ was found in the 18 year-old plot because of the high mortality of eucalypts. In the commercial plantation plots, undergrowth basal area was lower than $1 \%$ of the total.

\section{Discussion and Conclusions}

Exotic timber plantations initiated an important floristic change from the grass-dominated vegetation of native savanna toward undergrowth characterised by the importance of woody plants. The changing rate of the vegetation was slowed down by management practices or accelerated by high plantation density or by forest proximity. The basal area of undergrowth was low in all the studied plots, and far less than that of the planted trees.

Floristic change was characterised by the increase of total species number and the proportion of forest-preferring species, with increasing plot age. An increase in the number of species with plantation age is a common observation (Parrotta 1993, 1999; Abbasi and Vinithan 1999). Nevertheless, important differences in floristic composition still remained between natural secondary forest and plantation undergrowth. On one hand, many forest-preferring species observed under plantation were not found in the forest plot and, on the other hand, most species identified in the forest plot were not found in the plantation undergrowth. Undergrowth vegetation could be characterised as typical of a pioneer stage of forest succession. Nevertheless, the important proportion of ruderal species could be an indicator of plant community fragility.

Floristic change trends were different according to the planted tree species. Undergrowth in acacia plantations was very different to that of forest or other tree plantations, whereas under pine the spontaneous vegetation showed a trend towards that of the forest vegetation. In eucalypt plantations, undergrowth in undisturbed plots tended to be different from that of the forest and savanna, as in acacia plantations, whereas disturbances resulted in a vegetation nearer to savanna. Effects of nurse species on undergrowth floristics reported in the literature are variable, significant in Parrotta (1995a) and Keenan et al. (1997), but of little importance in Lugo et al. (1993). The proximity of natural forest may influence vegetation as far as $100 \mathrm{~m}$ (Parrotta 1993) or $300 \mathrm{~m}$ (Keenan et al. 1997) whereas in the Pointe-Noire site, the influence of forest proximity was important only at shorter distances.

A good understanding of the complexity of vegetation processes requires long-term monitoring of vegetation change. Further studies are needed. They could be focused on seed dispersion mechanisms, including biotic factors (birds and bats, see chapter 2) and abiotic factors (e.g. wind), and on specific heterogeneity of undergrowth with the presence of dense lowdiversity patches. More attention has to be paid to the variability of the floristic composition and densities in the undergrowth of the natural forest, which might affect undergrowth composition in nearby plantations, and to management practices. 


\title{
Chapter 2.
}

\section{Effect of Exotic Tree Plantations on Vertebrate Fauna}

\author{
A. Brosset ${ }^{1}$
}

\section{Introduction}

$\Omega$

he diversity and abundance of the vertebrate fauna was studied as an index of the environment quality. A study carried out in the Kouilou forest, $70 \mathrm{~km}$ north of PointeNoire, showed a rich diversity in the bird population (Dowsett-Lemaire and Dowsett, 1991). Although a comparable study is not available for the nearby savanna, an increased diversity of bird populations was hypothesised when forest plantations are grown on savanna soil. There are indications in the literature that the abundance of birds in old plots with dense undergrowth, might contribute to the dispersal of seeds, resulting in the maintenance and the increasing diversity and density of the undergrowth, as observed by Duncan and Chapman (1999). Abbasi and Vinithan (1999) found that the bird population was not less in eucalypt plantations (hybrid tereticornis $\mathrm{x}$ globulus) compared to the other planted species they studied. Bird populations in eucalypt, pine and acacia plantations were surveyed to test these observations and hypothesis (Brosset 1997).

\section{Study Sites and Methods}

An age series of eucalypts, a 16 year-old acacia and a 15 year-old pine plantation were selected in Pointe-Noire (Table 2.1). Most bird species were known from previous extensive studies in Gabon (Brosset 1990, 1997). In Congo, each selected area was surveyed during six hours, walking along the perimeter, then along transects 50 to $100 \mathrm{~m}$ apart,

with regularly spaced ten minute pauses. A list of the species encountered was prepared (Brosset 1997). Since the experimental plots which were selected for other measurements were too small for an adequate survey of bird populations, they were extended to a radius of about $500 \mathrm{~m}$. Occasional observations for mammals were made during the bird study.

\section{Birds}

\section{Bird ecological groups}

The nature of ecological relationships between plantations and their avifauna may be understood considering bird assemblages or "guilds". Six guilds were defined (Brosset 1997):

1. The guild of savanna ground feeder birds exploiting young plantations. It comprises two plovers (genus Charadrius and Vanellus), one cursor (genus Cursorius), two larks (genus Mirafra and Macronyx), one pipit (genus Anthus). These birds are invertebrate feeders.

\footnotetext{
1 Laboratoire d'Ecologie Végétale, Muséum National d'Histoire Naturelle, 4 avenue du Petit Château 91800 Brunoy, France.
} 
2. The guild of seed feeders inhabiting the edges of plantations. It comprises species of half-open areas, one serin (genus Serinus), two manikins (genus Lonchura), one widow bird (genus Vidua), and two pigeons (genus Turtur and Streptopelia). These birds exploit grass seeds along the edge of plantations, using trees for resting and sleeping in security. Some insect feeders such as Cisticolla are also common in the contact area.

3. The guild of invertebrate feeders exploiting undergrowth foliage. They are mostly wood Sylvidae belonging to the genus Phylloscopus and Camaroptera. Some flycatchers of the genus Tersiphone may also be present.

4. The guild of the frugivores. It comprises wood species, feeding on fruits produced by undergrowth plants, five barbets (genus Pogoniulus and Tricholaema), two bulbuls (genus Pycnonotus and Andropadus), and one thrush (genus Turdus). These frugivores build their nests in the undergrowth, barbets excepted. They probably play a key role for seed dispersal.

5. The guild of the nectarivores. They are essentially the souimanga of the genus Nectarinia, by far the most numerous birds in the plantations. They feed almost exclusively on nectar and pollen carbohydrates produced by the undergrowth flowers. Their role as pollinators is assumed to be very important. In natural eucalypt forest of Australia this guild is also the most numerous (Salter 1996) but the significance of eucalypt in this common occurrence is questioned.

6. The guild of birds using trees only as watching or resting places. It comprises species to which plantations have nothing to offer but observation posts. These species are met on the border of plantations, watching for prey living in the nearby open spaces. It is the case of two buzzards (Buteo buteo and B. auguralis), the honey buzzard (Pernis apivorus), three species of bee-eaters (genus Merops), two species of kingfishers (genus Alcedo and Hispidina), one shrike (genus Lanius), and two flycatchers (genus Muscicapa).

\section{Bird populations}

The survey yielded a total of 66 bird species in the plantations (Table 2.1), whereas DowsettLemaire and Dowsett (1991), who surveyed the natural ecosystems of the Kouilou region during about six months, found 125 species in similar areas. This figure may be considered as the potentially occurring number of species, and it is noteworthy that as many as $53 \%$ of them were observed in plantations within two weeks. Among the 66 species observed, only two, Nectarinia cuprea and Pycnonotus barbatus, were present in all plots studied except the pine plantation. Species which were the most adaptable in plantations were those which were geographically widespread, whereas endemic African species were not seen in plantations.

Table 2.1 Birds in eucalypt, acacia and pine plots: number of encountered species, and ratio: number of encountered species/125 number of potentially occurring species in natural environment

\begin{tabular}{cccc}
\hline Code & $\begin{array}{c}\text { Number of } \\
\text { species }\end{array}$ & $\begin{array}{c}\text { Species } \\
\text { potentially present } \\
(\%)\end{array}$ & $\begin{array}{c}\text { Number of } \\
\text { individuals }\end{array}$ \\
\hline Ea & 31 & 0.25 & 145 \\
Eb & 16 & 0.13 & 71 \\
Ec & 27 & 0.22 & 89 \\
Ed & 35 & 0.28 & $440-640^{*}$ \\
Ef & 30 & 0.24 & $280-480^{*}$ \\
Eo & 4 & 0.3 & 9 \\
A & 44 & 0.35 & 159 \\
$P$ & 0 & 0 & 0 \\
\hline Total & 66 & 0.53 & \\
\hline
\end{tabular}

*Occurrence of high density of the souimanga (Nectarinia cuprea), estimated 300 to 500 in the 17-year-old plot and 200 to 400 in the 21-year-old plot.

The species of planted tree has a great influence on bird species richness (Table 2.1). Many birds were observed in the acacia plot, and it was noticed previously that this species housed numerous insects. The pine plot studied was different from the plantation investigated for vegetation and soil fauna, and undergrowth was completely lacking; this could explain why no birds were observed. The influence of tree species was also observed by Petit et al. (1999) in various wooded vegetation types in Panama, and by Tassin and Rivière (1998) in various plantations in Reunion, although Lawton et al. (1998) did not find simple relationships. 
The presence of many species and individuals from the bird community, seems to be linked to the development of a naturally regenerating undergrowth vegetation, and the number of bird species and individuals was significantly related to the density and biodiversity of plants in the undergrowth. Relationships between number of birds and age of plot were not observed. The variability of plots regarding the number of species and the individual number of birds was assumed also to be partly linked to shape and size of plots: a longer edge compared to the area promote bird presence, activity and nutrition, and a large block with few understorey plants, as encountered at Hinda, was almost devoid of birds.

The type of undergrowth present affected bird use. When undergrowth was exclusively Chromolaena odorata, a spreading weed, no birds were observed. The plant association most occupied by birds combined Psychotria sp., Alchornea cordifolia, Maprounea and Canthium spp. Psychotria flowers, as well as those of another pioneer plant, Anthocleista sp., provide food for most nectarivorous souimanga, whereas the other three fruiting species provide food for the bulbul Pycnonotus barbatus and the genera Pogoniulus and Turtur. The only species that built their nests in eucalypt trees were souimangas, while some undergrowth trees, like Maprounea and Macaranga spp., were used for nesting by several species.

The number of migratory bird species and individuals from palearctic countries was relatively high. Seven species were observed two of which were present at fairly high densities. First, these birds prefer a vegetation which is physionomically similar to their native environment (Brosset and Erard 1986), and secondly, tropical forests are generally saturated with local sedentary species. However migratory birds were encountered in plots where the understorey vegetation was thick and varied.

\section{Mammals}

Mammals are known to scatter seeds and to improve their germination. In eucalypt plantations, in the short time available for the study, presence or signs of presence of mammals were noticed. Tracks of jackals, Canis adustus, which eat fruits, were seen everywhere, and individuals were observed several times during previous field trips and once during the present study. Tracks of civet, Civectictis civetta, which is known to be efficient in scattering seeds (Pendge 1994), were seen in and nearby eucalypt plots. One small forest bovidae, Cephalophus sp., was observed twice in previous studies, and tracks were seen once. Antelopes are intensively hunted and are probably scarce in the region (Wilson and Wilson 1991). Bats were not studied at night and one colony group of Micropteropus was observed during daytime. This frugivore bat is widely spread in Congo (Brosset 1966), and could play a significant role in seed dispersal.

\section{Conclusions}

Unlike in drier countries, where no undergrowth occurs in eucalypt plantations and few bird species are found (e.g. Smith 1974), higher rainfall in Congo permits development of undergrowth vegetation which favours the occurrence of bird species (Loumeto and Huttel 1997 and chapter 1, this report). Bird species which are able to colonise the plantations are those which utilise shrub-like vegetation, and the abundance of undergrowth determined the diversity and density of bird populations in the studied plantations. The same relationship could occur with mammals (Armstrong and Henbergen 1996). Moreover, the edges of the planted parcels along the alleys are more frequently used than the inner parts, and small parcels have higher bird densities than larger ones. It is noticeable, however, that the species planted is a main factor of bird colonisation, and trees like acacia with abundant herbivorous and detritivorous insects attract a great number of birds. 


\section{Part 2}

Biological Factors of Fertility Related to Organic Matter Dynamics 


\title{
Chapter 3.
}

\section{Litterfall, Litter Quality and Decomposition Changes with Eucalypt Hybrids and Plantation Age}

\author{
F. Bernhard-Reversat ${ }^{1}$, J.J. Loumeto ${ }^{2}$ and J.P. Laclau ${ }^{3}$
}

\section{Introduction}

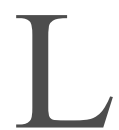

itterfall serves three main functions in the ecosystem: energy input for soil microflora and fauna, nutrient input for plant nutrition, and material input for soil organic matter development. The first two functions are completed through decomposition and mineralisation, and the third through decomposition and humification. Those functions are related to main soil processes, especially microbiological activity and soil fauna activity, litter quality and quantity. Annual litterfall in the Congolese eucalypt plantations was previously shown to be low compared to many natural tropical forests or to other fast growing trees (Loubelo 1990; Bernhard-Reversat 1993), and to have high content of phenolic compounds (BernhardReversat 1999) which are known to affect many biological processes. The hypothesis of the control of litter quality, quantity and decomposition by plantation age, management, and hybrid was studied.

\section{Studied Plots and Methods}

\section{Litter measurements}

Litterfall was measured in 6,13, and 19-year-old plots of Eucalyptus PF1 and an 8-year-old plot of Eucalyptus urophylla $\mathrm{x}$ E. grandis hybrid referred to as E. urograndis (plots Ep, Er, Et, Eu, Ev). As the plots were logged every 7 years, the trees were 6-7 years old in all plots except in the 19-year-old plot, where half of the area was never logged and the trees were 19 years old, and the other half was coppiced. The 8-year-old plot of $E$. urograndis (clone 18-85) referred to as (plot Ev), was also sampled to compare its litter production with that of PF1. In the 6-year-old PF1 (plot Ep), litterfall was sampled every week in 15 quadrats of $0.56 \mathrm{~m}^{2}$. In the other plots, litterfall was sampled in 10 quadrats of $0.25 \mathrm{~m}^{2}$, and sampling was made every week during the rainy season and every other week during the dry season. The quadrats were covered with 1-2 mm mesh plastic screen. Samples were oven-dried $\left(65-75^{\circ} \mathrm{C}\right)$ and weighed. Three fractions were sorted: leaves, twigs and bark, fruits and flowers. Samples from each four-week period were combined for nutrient analysis at the IRD Analysis Laboratory of Pointe-Noire. Unfortunately, except in 6-year-old plot Ep, this pattern was disturbed because the time lag between sampling, was occasionally longer and some quadrats' screens were sometimes stolen; consequently it was not possible to calculate the annual litterfall per quadrat for statistical purposes. Statistical analysis was made on the basis of

Laboratoire d'Ecologie des Sols Tropicaux, Centre IRD d'Ile de France, 32 avenue Henri Varagnat, 93143 Bondy, France.

2 Laboratoire de Biologie Végétale, Université de Brazzaville, BP 69, Brazzaville, Congo.

3 UR2PI, B.P. 1120, Pointe-Noire, Congo. 
litterfall per week, and comparisons took into account the overall results for a sampling time. Annual litterfall was calculated by multiplying the mean weekly litterfall for each plot by 52 .

Standing litter was sampled with a $6 \mathrm{~cm}$ diameter cylinder, and three cores were taken for each sample. Three replications were made in each plot. This rapid method gave good reproducibility and therefore allowed reliable comparisons between stands, but over-estimated by approximately $25 \%$ the results when compared with the usual single sampling of larger areas.

\section{Characterisation of leaf litter}

For the organic characterisation of litter, freshly fallen leaves, recognised by their colour, were picked up from the soil, and air-dried. Sampling was made in February 1998 and 1999. The thickness of the leaf blade was measured. It was measured between the main veins with a thickness gauge (by $0.01 \mathrm{~mm}$ ), after re-humidification of litter leaves in boiling water. Two measurements were made on each of ten leaves for each clone.

Air-dried and milled litter were chemically analysed and chemical contents were expressed as oven-dried weight $\left(75^{\circ} \mathrm{C}\right)$. Fibres were analysed by the method of Van Soest (1963) by determination of neutral detergent fibre (NDF), acid detergent fibre (ADF) and acid detergent lignin (ADL) at the CIRAD-AMIS Laboratory. With this proximate method, a variety of compounds are included in the so-called "hemicellulose", "cellulose" and "lignin" fractions but it is generally used for comparisons in plant material. Some samples were analysed for nitrogen on $100 \mathrm{mg}$ samples using a LECO FP $428 \mathrm{CHN}$ apparatus in the same laboratory, and in other samples nitrogen was determined as $\mathrm{NH}_{4}$ by the Nessler method after mineralisation in concentrated sulphuric acid with $\mathrm{H}_{2} \mathrm{O}_{2}$. Soluble $\mathrm{C}$ and soluble phenolics were extracted by mixing 1 or $2 \mathrm{~g}$ of litter in $60 \mathrm{ml}$ of cold water during two hours. Total extractable phenolic compounds were extracted according to the Tropical Soil Biology and Fertility Programme method (Anderson and Ingram 1993) by heating $0.5 \mathrm{~g}$ of litter in $50 \%$ (v:v) methanol in water at $80^{\circ} \mathrm{C}$ for one hour. The difference between methanol extracted phenolics and water extracted phenolics was referred to as "insoluble phenolics", and the phenolic compounds which were not extracted by methanol were not taken into account in this study. Soluble carbon was determined in water extracts by the chemical oxygen demand (COD) with the rapid $\mathrm{HACH}$ method (Anonymous 1994) and for conversion of COD to carbon, the assumption was checked previously that soluble carbon consisted mainly of glucids (Reversat 1981). Phenolic compounds were determined in water extracts and in methanol extracts by the tyrosine reagent (HACH method, Anonymous 1994) which takes into account all hydroxyled aromatic compounds.

\section{Iron mobilisation ability}

Litter solutions were made with $2 \mathrm{~g}$ in $60 \mathrm{ml}$ distilled water and 2 hours shaking. To perform iron extraction, $30 \mathrm{ml}$ of litter extracts were shaken for one hour with $5 \mathrm{~g}$ of a standard eucalypt soil (0-5 cm depth) and centrifuged. Iron was determined colorimetrically in the solution by the phenanthroline reactant after organic matter was mineralised with $\mathrm{H}_{2} \mathrm{O}_{2}$. Control extractions were made with distilled water.

\section{In vitro and in situ decomposition rates}

In vitro litter decomposition was studied by carbon mineralisation measurements of air-dried and milled fresh litter. Micro-litterbags (50 x $50 \mathrm{~mm}$ ) were made with $60 \mathrm{~mm}$ pore size nylon mesh. They were filled with $1 \mathrm{~g}$ of litter, which was humidified, with $2 \mathrm{ml}$ of soil solution (20 g of savanna soil mixed with $50 \mathrm{ml}$ of water for 30 minutes and decanted). Each bag was put in a jar with a beaker containing $50 \mathrm{ml}$ of $0.1 \mathrm{~N} \mathrm{NaOH}$, which trapped the $\mathrm{CO}_{2} . \mathrm{NaOH}$ determinations were made at intervals with $0.5 \mathrm{~N} \mathrm{HCl}$.

In situ decomposition rates were measured in $20 \mathrm{~cm} \times 20 \mathrm{~cm}$ litter bags, $1.5-2 \mathrm{~mm}$ mesh size each, with $10 \mathrm{~g}$ of air dried leaf litter, the oven dried weight being measured in another part of the sample. Litter bags were put on the soil surface in the same plot from which the litter came, in March, July and October, and were sampled after 4 and 12 weeks in the field with 12 replications at each date (in some cases, a few replications were lost). The decomposed litter was dried at $75^{\circ} \mathrm{C}$ and weighed. 


\section{Results and Discussion}

\section{Litterfall}

Annual litterfall ranged from $6.9 \mathrm{t} \mathrm{ha}^{-1}$ in the younger plot to $12.8 \mathrm{t} \mathrm{ha}^{-1}$ in the old first rotation plot (Table 3.1). Total litterfall and leaf litterfall were significantly different among plots, unlike wood litterfall. Fruits fell only in the 19-year-old first rotation plot. In the young 6-year-old first rotation plot the result was close to the $6.5 \mathrm{t} \mathrm{ha}^{-1}$ which was found previously in another PF1 plot (clone 1-45) (Bernhard-Reversat 1993). It was higher than in dry tropical or Mediterranean eucalypt plantations where litterfall was 2-3 tha-1 $\mathrm{yr}^{-1}$ (Knokaert 1981 in Morocco; BernhardReversat 1987 in Senegal; Abelho and Graça 1996 in Portugal). In temperate natural eucalypt forests litterfall was of the same order of magnitude as found in Congo at the same age (Polglase and Attiwill 1992). In Puerto Rico, Parrotta (1999) found an annual average of $5.4 \mathrm{t} \mathrm{ha}^{-1}$ in younger tropical plantations. When compared to nitrogen fixing plantations, eucalypt had generally a lower litterfall (Parrotta 1999; Bernhard-Reversat and Loumeto, in press).

Litterfall increased with aging of plantations, and was also influenced by harvest operations and between hybrids. Although the trees were approximately of the same age, leaf litter production was significantly lower in the young 6-year-old first rotation plot than in the older 13year-old coppice plot (about 6 years of coppice growth). Previous observations (BernhardReversat 1993) reported that the litterfall of 2-yearold $E$. PF 1 coppice plot was the same as that of the former 7-year-old first rotation crop in the same plot. This suggested a rapid growth of the canopy in the coppice, allowed by the expanded rooting system. The lower litter production in the 19-yearold coppice compared to the 13-year-old coppice, and to the 19-year-old unlogged first rotation crop, might suggest the physiological aging of the stock, the depletion of soil nutrient by export (Steward et al. 1988, Miranda et al. 1998) or the alteration of the roots by parasitic nematodes (Loubana and Reversat, chapter 6), together with the possible decrease of nutrient availability.

Eucalyptus urograndis had a significantly higher leaf litterfall $\left(6.8 \mathrm{t} \mathrm{ha}^{-1} \mathrm{yr}^{-1}\right)$ than the young first rotation plot of $E$. PF1 (4.3 $\left.\mathrm{tha}^{-1} \mathrm{yr}^{-1}\right)$. The age of the trees differed by two years and might explain the difference in litterfall, although a linear regression with the 6-year-old and the 19-year-old first rotation plot litterfall gave $5.2 \mathrm{t} \mathrm{ha}^{-1}$ for a 8 year-old $E$. PF1 plot. It was shown previously that the leaf biomass of four $E$. urograndis clones was about $30 \%$ higher than the leaf biomass of $E$. PF 1 , clone 1-41 (Safou-Matondo et al. 1999). During the study of an age series of E. PF1 (clone 1-41) by Laclau (unpublished data), a very low amount of litterfall was collected during the first year after planting $\left(0.4 \mathrm{t} \mathrm{ha}^{-1} \mathrm{yr}^{-1}\right)$ and was only leaves. Between the second year and the logging age, leaf litterfall remained stable (about $4 \mathrm{tha}^{-1} \mathrm{yr}^{-1}$ ) while the amount of wood and bark litterfall increased up to the fourth year after planting. Parrotta (1999) also observed a relatively steady litterfall from the second to the fourth year of plantation.

\section{Nutrients in litterfall}

Similar values of leaf litter nutrient concentration were observed for the different plots and neither plot age nor previous exploitation appeared to have an effect on nutrient contents (Fig. 3.1). Eucalyptus urograndis leaf litter was not different from $E$. PF1 except for a higher $\mathrm{P}$ concentration. Laclau et al.

Table 3.1 Annual litterfall in eucalypt plots $\left(\mathrm{g} \mathrm{m}^{-2} \mathrm{yr}^{-1}\right.$ with standard error in brackets)

\begin{tabular}{|c|c|c|c|c|c|c|c|}
\hline \multirow[t]{2}{*}{ Plot } & \multirow[t]{2}{*}{ Stand type } & \multirow[t]{2}{*}{$\begin{array}{c}\text { Eucalypt } \\
\text { hybrid }\end{array}$} & \multirow{2}{*}{$\begin{array}{c}\text { Plot age } \\
(y r)\end{array}$} & Leaves & $\begin{array}{l}\text { Twigs and } \\
\text { bark }\end{array}$ & Fruits & Total \\
\hline & & & & \multicolumn{4}{|c|}{$\left(\mathrm{g} \mathrm{m}^{-2} \mathrm{yr}^{-1}\right)$} \\
\hline Ep & Seedling & PF 1 & 6 & $431(75)$ & $256(80)$ & 0 & 688 (107) \\
\hline $\mathrm{Er}$ & Coppice & PF 1 & 13 & $831(27)$ & $256(48)$ & 0 & $1087(54)$ \\
\hline Et & Coppice & PF 1 & 19 & $664(28)$ & 271 (37) & 0 & $938(46)$ \\
\hline $\mathrm{Eu}$ & Coppice & PF 1 & 19 & $888(44)$ & $378(57)$ & $25(3)$ & $1290(76)$ \\
\hline Ev & Seedling & urograndis & 8 & $684(27)$ & $320(72)$ & 0 & $1004(77)$ \\
\hline
\end{tabular}


(2000a) reported an increase of leaf $\mathrm{N}$ content with age and a decrease of $\mathrm{P}, \mathrm{K}, \mathrm{Ca}$, and $\mathrm{Mg}$ in young plantations from 1 - to 7 -year-old, but no information was available for older plantations. Polglase and Attiwill (1992) observed little variation in leaf $\mathrm{N}$ content in 5- to 80-year-old eucalypt stands in Australia. A trend for the concentration in N, P and $\mathrm{K}$ in leaves and in leaf litter from 1- to 8-year-old eucalypt plantations to decrease was shown by Bargali et al. $(1992,1993)$. The decrease in leaf litter nutrient concentration during the first years of plantation might decrease and disappear when the accumulation of litter on the soil allows nutrients to be partly involved in direct litter-root cycling.

Figure 3.1 Nutrient content of leaf litter of eucalypt plots at different plot ages. The 8-year-old is $E$. urograndis, the others are E.PF1

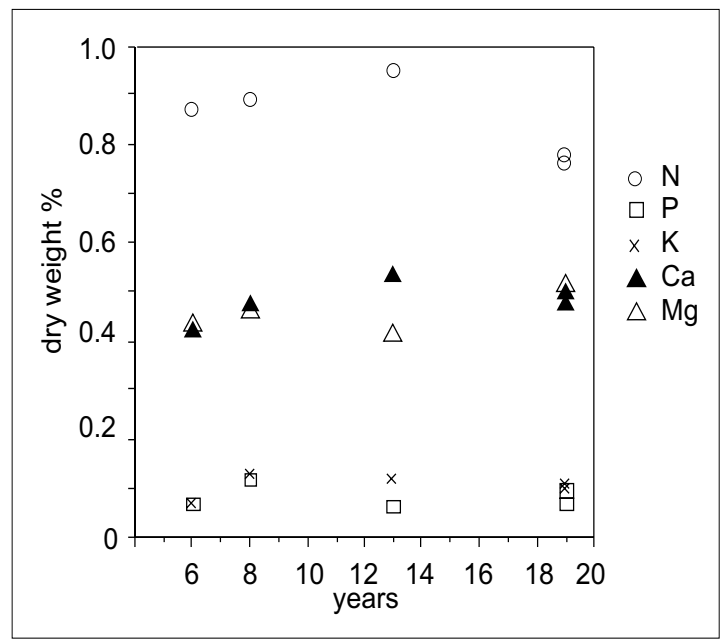

As a consequence of the low variations in nutrient concentration, nutrient input to the soil through litter varied mainly according to the amount of litterfall (Fig. 3.2) and decreased in the coppice that was twice logged, reinforcing the hypothesis of nutrient shortage due to exploitation.

\section{Leaf litter blade thickness}

The differences in leaf litter blade thickness among eucalypt clones, calculated with individual leaf measurements, were highly significant (ANOVA, $\mathrm{p}<0.0001)$. Leaf litter thickness was significantly different among hybrids $(\mathrm{p}<0.001)$, years of sampling $(\mathrm{p}=0.01)$, and production levels $(\mathrm{p}<0.01)$. The year effect might be due to rainfall amount or distribution. For each hybrid, leaves from high production clones are thicker than leaves from low production clones and it needs to be determined if this corresponds to thicker photosynthetic parenchyma. Blade thickness was correlated to the (Van Soest 1963) hemicellulose content and to leaf litter $N$ content $(p<0.05)$, and this last relationship could contribute to the relationship with production (Fig. 3.3).

\section{Leaf litter organic compounds}

\section{Water soluble carbohydrates}

The average soluble carbon content was $105 \mathrm{mg}$ $\mathrm{g}^{-1}$ of litter, which is equivalent to $26 \%$ of dry weight if expressed as soluble organic matter, and it ranged from 15 to $35 \%$ of dry weight. However,

Figure 3.2 Annual nutrient input to the soil by litterfall in eucalpt plots

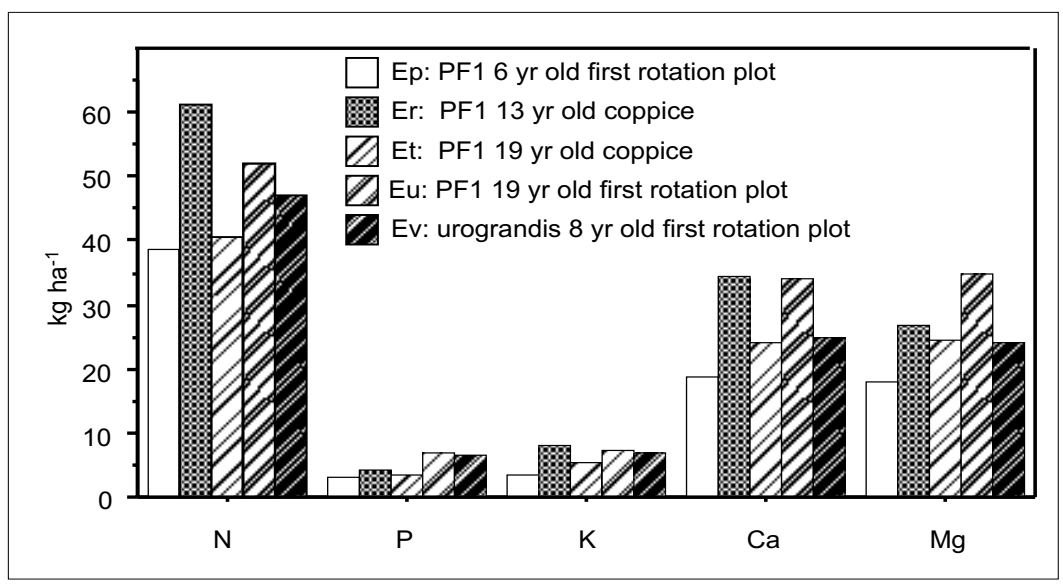


Figure 3.3 Eucalypt leaf blade thickness, hemicellulose (Van Soest) and total $\mathrm{N}$ contents
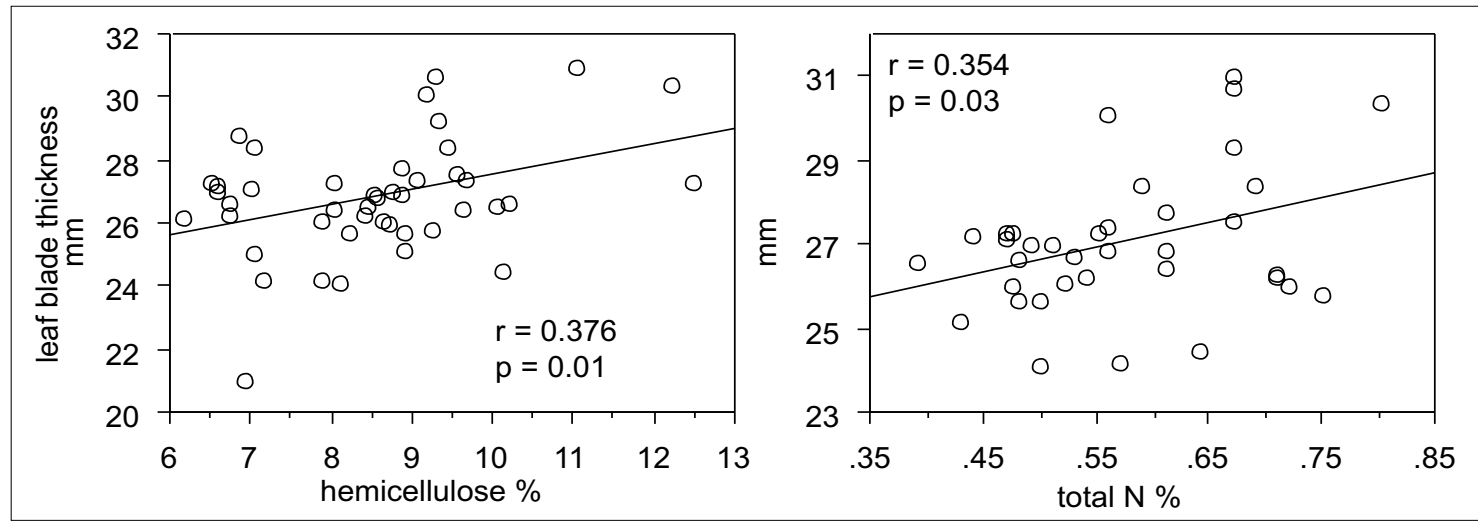

Table 3.2 Fibre content of leaf litter of two eucalypt hybrids (\% of dry weight with standard error in brackets), estimated by the Van Soest method

\begin{tabular}{lccc}
\hline Fibre & $\begin{array}{c}\text { E. PF 1 } \\
\% \text { of dry weight }\end{array}$ & $\begin{array}{c}\text { E. urograndis } \\
\mathrm{p}^{*}\end{array}$ & Significance \\
\hline Hemicellulose & $8.5(1.4)$ & $8.6(1.5)$ & Not significant \\
Cellulose & $15.9(0.9)$ & $14.3(1.7)$ & 0.0004 \\
Lignin & $16.4(1.5)$ & $15.5(1.7)$ & 0.06 \\
\hline
\end{tabular}

${ }^{*} p=$ probability for significant differences between eucalypt hybrids.

this large range of variation was related neither to hybrids nor to production level nor to plot age, and neither did non-phenolic soluble organic matter when soluble phenolics were considered separately.

The average water-soluble phenolic compounds were $9.5 \%$ of dry weight, and $36 \%$ of soluble organic matter. Soluble phenolic content was correlated with non-phenolic soluble carbon content $(\mathrm{p}<0.01)$. ANOVA analysis showed a significantly higher phenolics content in $E$. urograndis than in $E$. PF1 $(\mathrm{p}<0.01)$. When coppice and first rotation crops were compared in the 19year-old plots, soluble phenolic content was the only litter characteristic that was different, and coppice litter had a lower soluble phenolic content. Water soluble phenolic content of eucalypt was high compared to most other tropical tree species which we analysed previously (Bernhard-Reversat 1998). Most other data record methanol soluble phenolic contents (Palm and Rowland 1997) rather than water soluble contents. However, in our case we found the water soluble fraction to be more relevant for decomposition (Bernhard-Reversat 1998) and faunal activity studies (chapter 7).
Fibres and methanol extractable phenolic compounds

The average concentration of "insoluble" phenolic compounds (methanol extractable minus water extractable) was $70 \mathrm{mg} \mathrm{g}^{-1}$, and the range was 26 $93 \mathrm{mg} \mathrm{g}^{-1}$. Variations were not related to hybrids or clones.

The lignin concentration of eucalypt litter was found to be low compared to tropical species and to Congolese natural forest litter (Anderson and Swift 1983; Bernhard-Reversat and Schwartz 1997), although in the range of concentration given by Constantinides and Fownes (1994) for a number of tropical trees. Cellulose and lignin contents are significantly different between hybrids (Table 3.2). Most $E$. PF1 clones had a higher fibre content than $E$. urograndis clones. When considering E. PF1 alone, lignin concentration decreased significantly with plot age $(p<0.0001)$. Although the relationships between litter organic composition and plantation age were scarcely studied, lignin was not related to plot age in the agroforestry species studied by Nyathi et al. (1991). 


\section{Nitrogen}

Nitrogen concentrations exhibited a wide range of variation from 0.39 to $0.80 \%$, with an average of $0.57 \%$. The two different chemical analysis methods were taken into account for ANOVA analysis, and the two hybrids have significantly different $\mathrm{N}$ content; the averages were $0.61 \%$ for $E$. PF1 and $0.54 \%$ for $E$. urograndis.

\section{Iron mobilisation}

Ellis (1971) in Australia observed iron mobilisation by eucalypt litter extracts, and percolates of $E$. PF1 were shown previously to mobilise iron (Bernhard-Reversat 1999). Ellis (1971) and Enright (1978) related this effect to podzolisation. Iron mobilisation ability of $E$. PF1 and $E$. urograndis litter extract was high. The observed range in iron mobilisation in the studied samples (ranging from 1.1 to $1.6 \mathrm{mg} \mathrm{ml}^{-1}$ ) was narrow, and it was not significantly different between either hybrids or clones. Although phenolic compounds, with organic acids, are known to be responsible for soil iron mobilisation (Pohlman and McColl 1988), the relationship found here was negative, and the ratio extracted $\mathrm{Fe} /$ soluble phenolics was higher in $E$. PF1 than in $E$. urograndis. The suggested hypothesis that phenolics compounds differed in quantity or quality in the two hybrids will be investigated in further studies.
Figure 3.4 Estimated standing litter accumulated on the soil of eucalypt plots (over-estimated due to the sampling method)

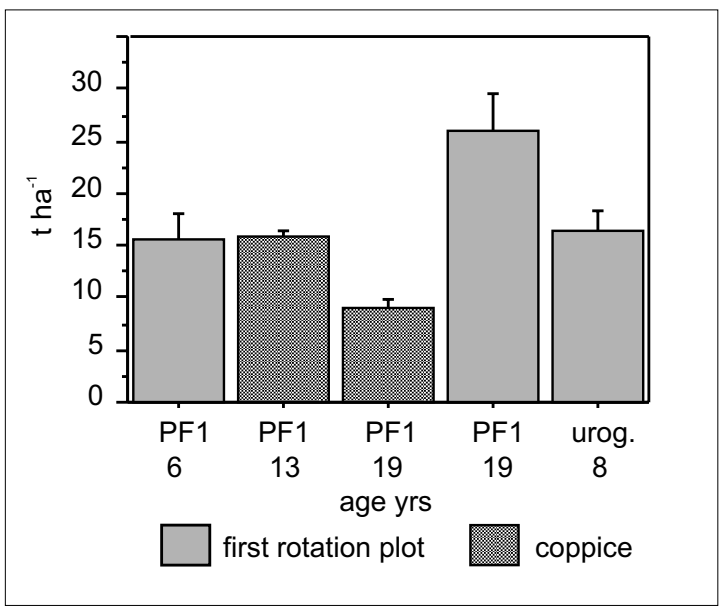

\section{Leaf litter accumulation and decomposition}

Stand harvests appeared to decrease sharply the amount of standing litter, which otherwise increased with plot age and reached high values (Fig. 3.4). The decomposition coefficient was previously calculated in a 7- to 8-year-old $E$. PF1 plantation and was shown to be low (BernhardReversat 1993). In the present litterbag experiment, 25 to $30 \%$ of dry weight was lost in three months. The ANOVA showed a highly significant effect of plot and season $(p<0.0001$,

Figure 3.5 Leaf litter decomposition rate after 4 and 12 weeks in three experiments in different seasons

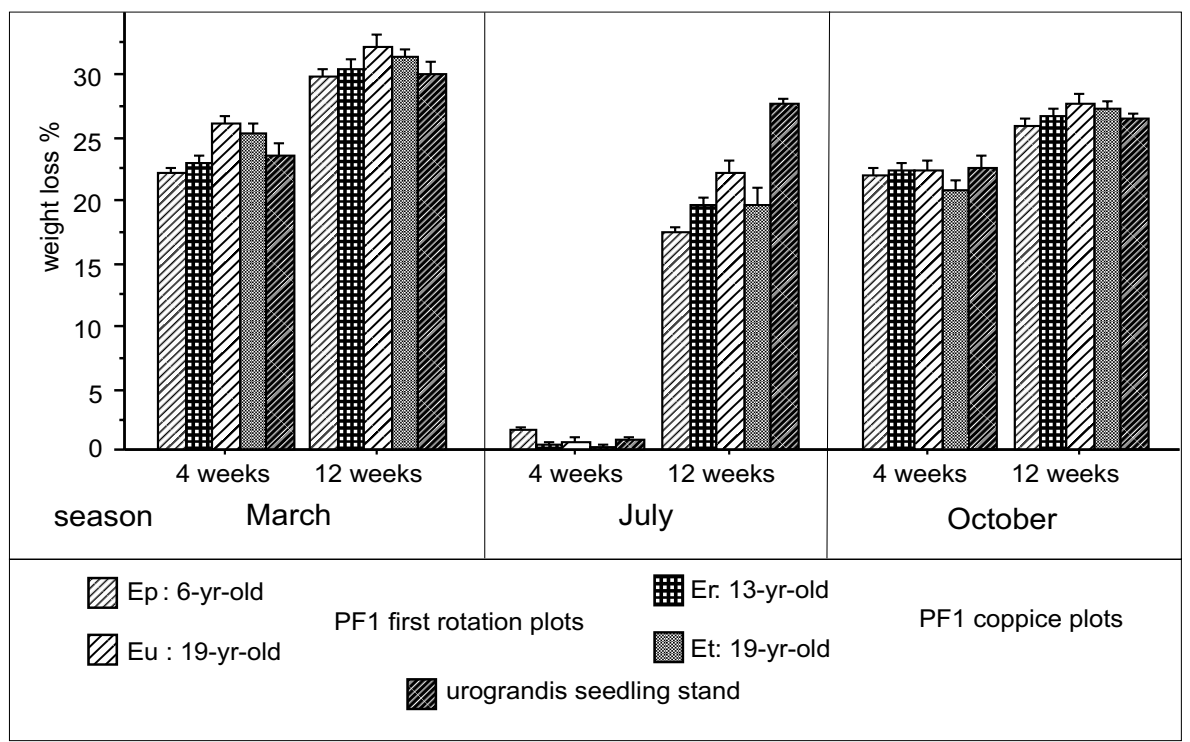


Fig. 3.5). The plot effect was due to a slight increase of decomposition rate with plot age and a higher $(\mathrm{p}<0.05)$ one in the first rotation plot than in coppice when compared in the 19-year-old plots, suggesting an effect of litter quality. The slow decomposition in tropical plantations compared to natural forest, especially in eucalypt and pine plantations, has been observed by numerous authors and stressed in some reviews (O'Connell and Sankaran 1997; BernhardReversat and Loumeto 2001). The decrease in lignin content with age could account for increasing decomposition rate. Such an increase in decomposition rate with plot age was observed for subtropical tree fine roots by Arunachalam et al. (1996) together with lignin content decrease.

The difference between hybrids changed according to seasons; during the rainy season (experiments beginning in March, October or January), decomposition rates were only slightly higher in $E$. urograndis compared to E. PF1 (8and 6-year-old respectively); during the dry season the litter of $E$. urograndis decomposed significantly faster than the litter of PF1. Differences in litter fauna activity might explain this observation but fauna observations (Mboukou-Kimbatsa et al. 1998) were not made during the dry season.

\section{Conclusions}

The litter system is highly dependent on the management factors: the results suggest that plot age, exploitation, and hybrid have an effect on litter quality and decomposition rate. Although these effects are small as measured values, they are significant and might influence nutrient cycling and soil organic matter accumulation and could also control microbiological and faunal activity. The aging of plots appeared to improve the functioning of the litter system. Logging operations create major disturbance of litter decomposition dynamics. 


\title{
Chapter 4.
}

\section{Soil Fertility Changes with Eucalypt Hybrids and Plantation Age: Soil Organic Matter}

\author{
J.J. Loumeto ${ }^{1}$ and F. Bernhard-Reversat ${ }^{2}$
}

\section{Introduction}

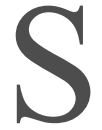

oil organic matter in the plantations originates from eucalypt litter and from the previous savanna vegetation (Trouvé et al. 1994). The amount of organic input in savanna is low and originates mainly from dead roots due to annual burning. Soils planted with eucalypts have a low organic matter content together with low clay and nutrient contents. Increasing organic matter improves the nutrient status of soil, and is also assumed to improve biological activity and soil structure. Therefore any research and knowledge improvement in this area is of tremendous importance for nutrient conservation in the plantations, especially when grown on poor soils.

It was shown previously that soil organic matter content was the same in savanna soil and in a 7year-old eucalypt plantation, and that it increased later, mainly due to light fraction increase (Bernhard-Reversat 1991). Observations carried out in other situations have either confirmed the above trend or shown different patterns of change. Trouvé et al. (1994) and Binkley and Resh (1999) showed that under eucalypt plantations, organic matter originating from the native savanna decreased whereas organic matter from eucalypt increased; therefore total $\mathrm{C}$ content did not change for several years. Parrotta (1999) also observed that no significant change in soil $\mathrm{C}$ occurred in 7.5-year-old eucalypt plantations established on a grassland soil in Puerto Rico. Jaiyeoba (1998) observed that soil organic matter decreased in eucalypt plantations grown on savanna soil during the first years and increased at a later age. Other observations showed organic matter decrease in eucalypt plantations grown on C-poor soils (Bernhard-Reversat 1988; Nandi et al. 1991; King and Campbell 1994). In the arboretum studied by Lugo et al. (1990) in a rain forest area where several planted species were compared, soil organic matter content either increased or decreased according to the species, and organic matter contents in eucalypt plots were among the highest. The aim of the present study was to investigate changes in soil fertility with a selected clone, and to assess the effect of plot age, exploitation and hybrids on soil organic matter, nitrogen and cation exchange capacity.

\section{Studied Plots and Methods}

The study was carried out on seven planted plots either harvested or not (Ep, Eq, Er ,Es, Et, Eu, Ev) and on savanna $(\mathrm{Sb})$ (Table 0.3$)$. Six composite samples were made in two layers $(0-10 \mathrm{~cm}$ and $10-20 \mathrm{~cm}$ ) in each plot. Each composite sample comprised four cores were which were extracted, close to each other, with a $62 \mathrm{~mm}$ diameter tube

\footnotetext{
1 Laboratoire de Biologie Végétale, Université de Brazzaville, BP 69, Brazzaville, Congo.

2 Laboratoire d'Ecologie des Sols Tropicaux, Centre IRD d'Ile de France, 32 avenue Henri Varagnat, 93143 Bondy, France.
} 
sampler after removing the litter layer. Each composite sample was air dried for analysis. From the six replicates, three were made in February and three in April. A slight difference between dates was significant and was taken into account to assess the significance of plot differences.

Particle size fractionation was made in the 0-5 cm layer. For this purpose, three composite samples were made in each plot, from three cores extracted with a $62 \mathrm{~mm}$ diameter tube sampler together with the litter layer. Each composite sample was air dried and fractionated. The litter fraction was sorted by dry sieving at $4 \mathrm{~mm}$ and $2 \mathrm{~mm}$ and soil fractionation was performed by wet sieving according to Balesdent et al. (1991) to sort three light organic fractions $(0.5-2 \mathrm{~mm}$, 0.2-0.5 mm, 0.05-0.2 $\mathrm{mm}$ ) and two organomineral fractions $(0.02-0.05 \mathrm{~mm},<0.02 \mathrm{~mm})$. Each fraction was analysed for $\mathrm{C}$ and $\mathrm{N}$ and the analysis of residual $\mathrm{C}$ in the mineral fraction was used to correct the organic fraction data. To assess the contribution of organic matter to cation exchange capacity (CEC), analysis of CEC was made on soil samples in which organic matter was removed by oxidation with hydrogen peroxide and on control samples. The above $0-10 \mathrm{~cm}$ soil samples were used.
Carbon was determined by the Walkey and Black method, nitrogen by the Kjeldahl method, and CEC by the ammonium acetate method.

\section{Results and Discussion}

\section{Organic matter particle size fractions}

Particle size fractions were studied in the $0-5 \mathrm{~cm}$ layer of soil. The amount of organic matter in each fraction, expressed as mg C per $\mathrm{g}$ of soil, was different between plots ( $\mathrm{p}$ ranging from 0.007 to 0.0001 with ANOVA) for all fractions except for F4-C (coarse loam) (Fig. 4.1).

The amount of organic matter in light fractions $(>0.05 \mathrm{~mm}, \mathrm{~F} 1, \mathrm{~F} 2, \mathrm{~F} 3)$ was greater in the first rotation crop soil than in the coppice soil when the 19 -year-old plots were compared $(\mathrm{p}=0.05$, test of Mann-Whitney). Litterfall and litter accumulation on the soil were also greater in the first rotation crop than in the coppice, increasing organic matter input to the soil. Although assessed only on five plots, a significant relationship $(p=0.01)$ between coarse light fraction $\mathrm{C}$ and litter disappearance in litterbags during the rainy season, either March or October, was observed (Fig. 4.2 and see chapter 3 ). Organo-mineral fractions were

Figure 4.1 Carbon in light organic fractions and organo-mineral fractions in the $0-5 \mathrm{~cm}$ layer of soil in eucalypt plots

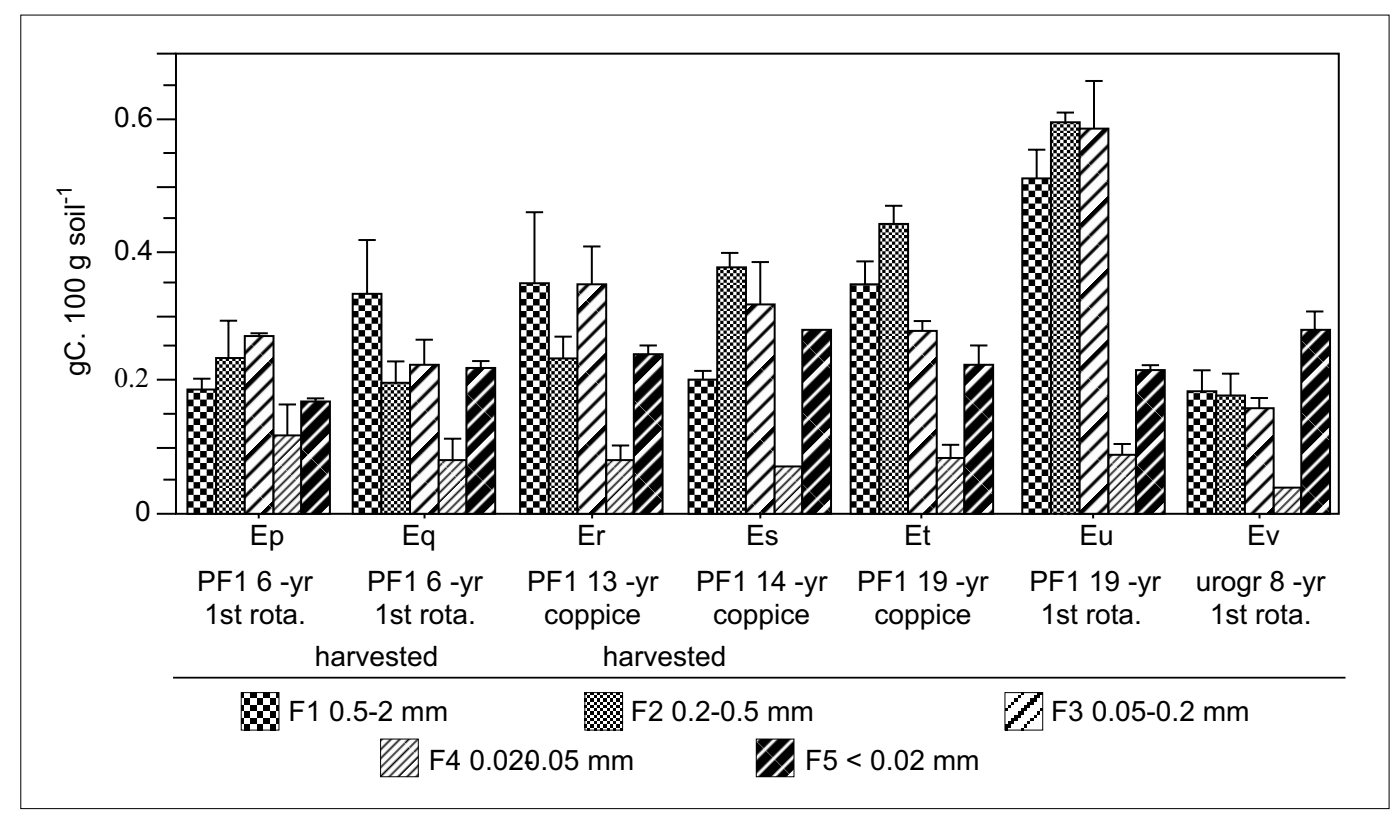


not affected. Tree logging every 6-7 years did not prevent organic matter accumulation but it decreased the accumulation rate. The comparisons of hybrids in the young first rotation plots did not show any significant differences for F1 and F2 fractions, perhaps because of a too high variability. The F3 fraction was significantly lower in $E$. urograndis than in E. PF1 ( $\mathrm{p}=0.05$ test of MannWhitney).

The amount of soil organic matter in the various organic fractions increased with plot age whereas the amount of soil organic matter in the organomineral fractions did not (Fig. 4.3), as found previously (Bernhard-Reversat 1991). Feller et al. (1991) pointed out the importance of light fractions for organic matter accumulation in sandy soils. Harmand (1998) in Cameroon observed in a more clayey soil that $\mathrm{C}$ in organo-mineral fraction increased under Acacia polyacantha and not under

Figure 4.2 Relationship between $C$ in coarse particlesize fractions of (total soil) and eucalypt litter decomposition in litter bags expressed in percent of initial weight (March-May)

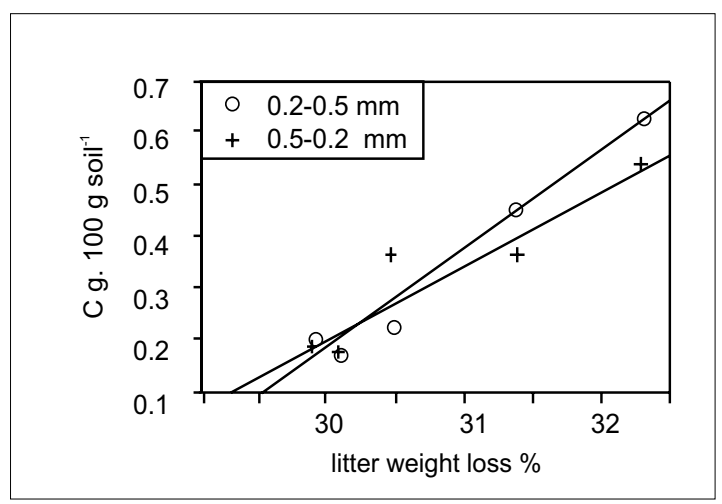

Eucalyptus camaldulensis, and it could be possible that some humification processes are lacking or slow in eucalypt litter (Bernhard-Reversat and Schwartz 1997)

\section{Carbon and nitrogen}

An ANOVA (Fig. 4.4) showed significant differences in $\mathrm{C}$ content between plots $(\mathrm{p}=$ $0.0002)$, plot average ranging from 6.7 to $11.1 \%$ in the $0-10 \mathrm{~cm}$ layer and from 5.0 to $5.7 \%$ in the 10-20 cm layer. Carbon content increased significantly with plot age $(\mathrm{r}=0.548, \mathrm{p}<0.001)$ in the $0-10 \mathrm{~cm}$ layer, but not in the $10-20 \mathrm{~cm}$ layer (Fig. 4.5). The highly productive hybrids grown

Figure 4.3 Amounts of $C$ in soil particle size fractions versus plot age in eucalypt plantations

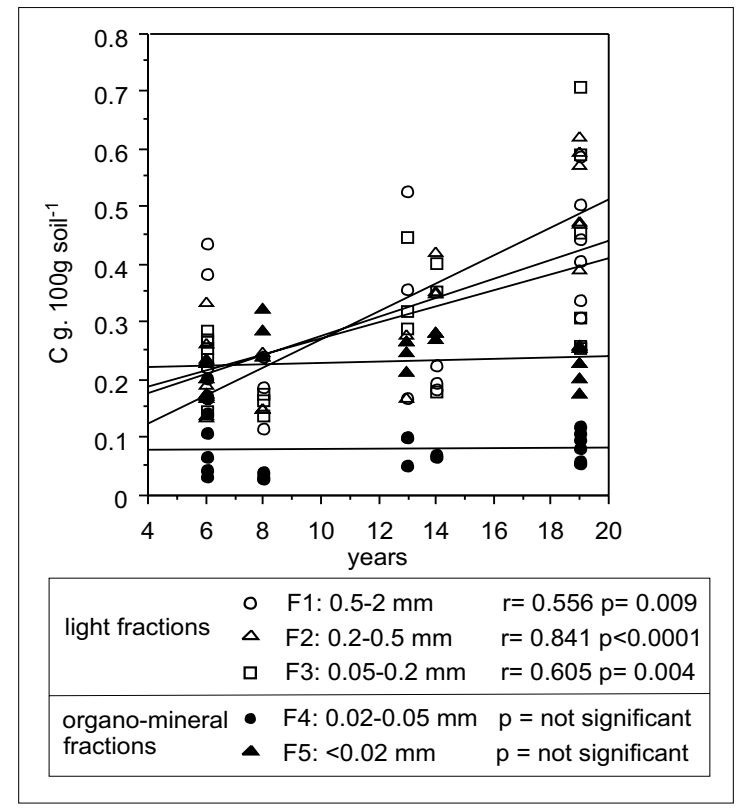

Figure 4.4 Mean carbon content of soil at two depths in various eucalypt plots

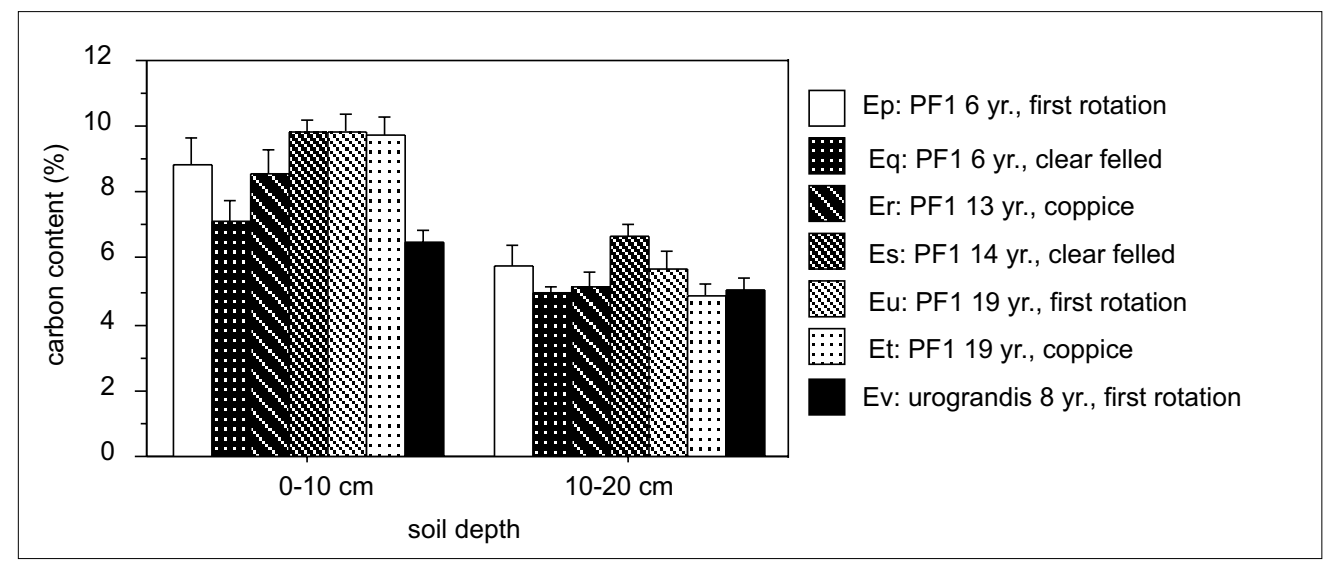


in Congo might have a higher litterfall which could explain soil $\mathrm{C}$ increase with age.

The relationship between plot age and $\mathrm{C}$ content in the $0-10 \mathrm{~cm}$ layer of soil did not seem to depend on management practices (Fig. 4.5): there was no significant difference either between first rotation crop and coppice when plots were 19-20 years old, or between harvested and forested plots. Hybrids alone had a significant effect, and C content was significantly lower in the $E$. urograndis plot than in the $E$. PF1 plot of similar age $(\mathrm{p}=0.02)$.

A small but significant decrease in $\mathrm{N}$ content was observed in the $0-10 \mathrm{~cm}$ soil layer of a 7 -yearold eucalypt plantation (another hybrid, HS2) compared to savanna (Bernhard-Reversat 1996).
In the PF1 hybrid studied here the decrease in $\mathrm{N}$ content of soil organic matter ( $\mathrm{N} / \mathrm{C}$ ratio) was more strongly marked and went on as plantations aged and it could be related to changes in litter quality resulting in an increase of $\mathrm{N}$ mineralisation rate compared to savanna. The $\mathrm{N}$ content in organic matter of the $0-10 \mathrm{~cm}$ layer of soil (N/C ratio) was slightly significantly lower $(\mathrm{p}=0.05)$ in $E$. urograndis than in $E$. PF1 plots. This observation deserves to be confirmed using more samples, because it could be related to $\mathrm{N}$ mineralisation reduction by the higher soluble phenolic content of $E$. urograndis litter, as observed in litter (Fox et al.1990; Constantinides and Fownes 1994) although such effect was not found in soil by Aggangan et al. (1999). An increase in soil C/N

Figure 4.5 Effect plot age and management practices on the soil carbon content of the $0-10 \mathrm{~cm}$ and $10-20$ layers of soil in eucalypt plantations

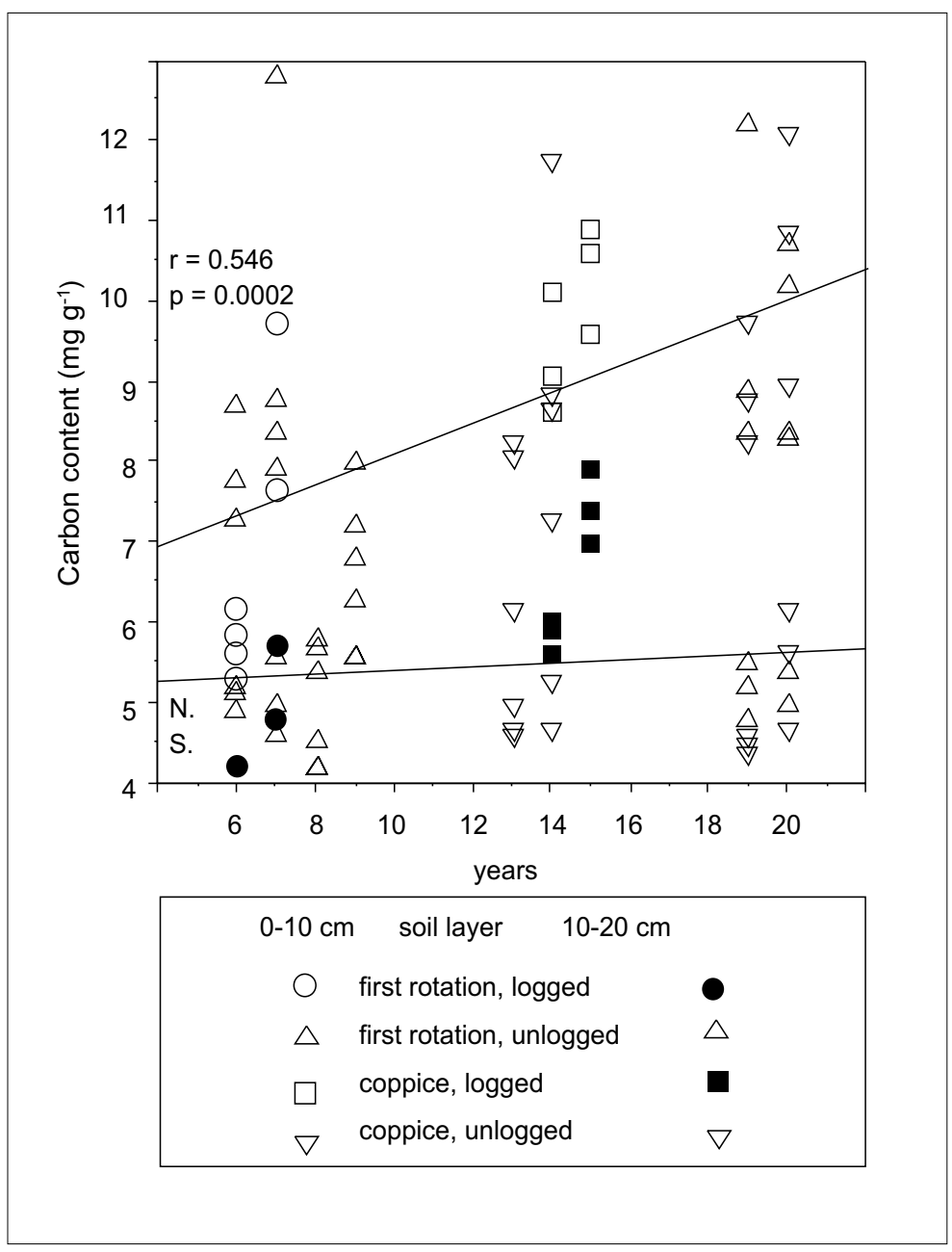


Figure 4.6 Relationships between plot age and the $\mathrm{C} / \mathrm{N}$ ratio of particle size fractions in eucalypt plots

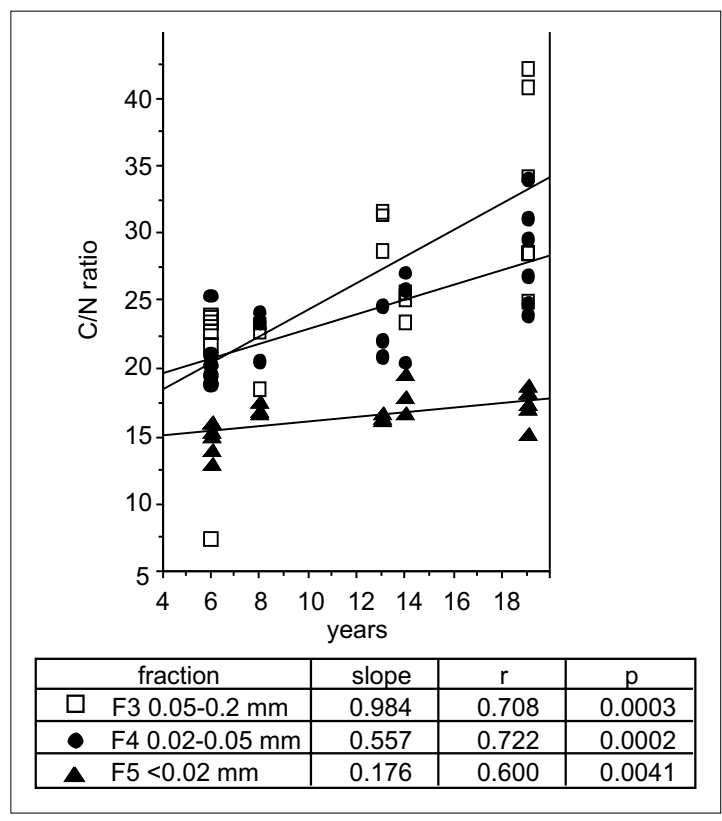

ratio (decrease in organic matter $\mathrm{N}$ content) under eucalypt plantations was observed by King and Campbell (1994) who ascribe it to poor litter quality.

The $\mathrm{C} / \mathrm{N}$ ratio did not change with age in the coarse light fractions, whereas it did in the fine light fraction and in the organo-mineral fractions (Fig. 4.6), showing that the decrease in $\mathrm{N}$ content of soil organic matter, described above, resulted from a lower $\mathrm{N}$ content of the fine organic matter. Nitrogen decrease was also observed by Binkley and Resh (1999) and this could confirm the observation on the changing organic matter origin from savanna material to eucalypt material underlined by these authors and Trouvé et al. (1994) with ${ }^{13} \mathrm{C}$ analysis, even when organic matter amounts did not change. Madeira et al. (1989) also observed an increase in the $\mathrm{C} / \mathrm{N}$ ratio of soil organic matter fractions in eucalypt plantation compared to the previous Quercus forest.

\section{Organic matter contribution to CEC}

Cation exchange capacity (CEC) was significantly different among plots. Plot management practices (logged compared to unlogged and first rotation crop compared to coppice) had no influence on CEC. Cation exchange capacity increased with age. When organic matter was destroyed by
Figure 4.7 Change of CEC with the age of eucalypt plots in the $0-10 \mathrm{~cm}$ layer of soil, before and after organic matter destruction

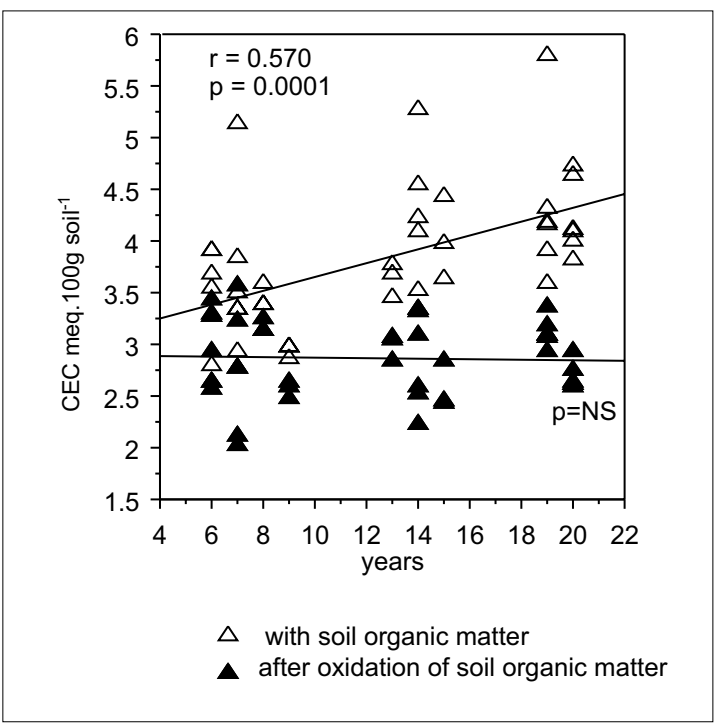

oxidation, the remaining CEC, mainly due to clay, was not related with age (Fig. 4.7), whereas the difference with total soil CEC, assumed to be due to organic matter exchange sites, was highly correlated with age $(\mathrm{r}=0.62, \mathrm{p}<0.0001)$. Although this process occurred only in the top layer of soil $(0-10 \mathrm{~cm})$, it may be of significance for tree nutrition because a great part of eucalypt fine roots is in this layer.

\section{Conclusions}

Soil organic matter changes are strongly related to plot age, although organic matter accumulation did not begin before 6-7 years after planting. The increase in soil organic matter was related to the highly productive hybrids that are grown in Congo However, the nitrogen content of the soil organic matter decreased with plantation age due to efficient nitrogen mineralisation and tree growth needs. This might result in a severe lack of nitrogen in aging coppice stands in the absence of nitrogen fertilisation.

The soil organic matter component was apparently less affected by harvest practices than the litter system, and previous exploitation did not show any important effect. An approximate estimate according to Laclau et al. (2000a) gave $22 \mathrm{t} \mathrm{ha}^{-1}$ for the part of biomass assumed to stay on the ground after clear felling in a 7-year-old 
plot. If each harvest brings to the soil approximately this amount of residue, accounting for the equivalent of $3 \mathrm{t} \mathrm{yr}^{-1}$, it could make up for the annual difference of litterfall input between the 19-year-old coppice and the first rotation crop. The branch wood which is left on the soil may be easily humified because its lignin is less polymerised than that of the stem wood, and it has a higher nutrient content (Lemieux 1996). Although eucalypts are among the less efficient species for improving soil nutrient status (O'Connell and Sakaran 1997) when grown on the poor savanna soils of Congo, their litter contributes to soil fertility increase after 6 to 7 years of plantations. 


\section{Part 3}

Biological factors of fertility related to the diversity and density of soil biota 


\title{
Chapter 5.
}

\section{Asymbiotic Nitrogen Fixation in Savanna and Eucalypt Plantations}

\author{
J. Le Mer ${ }^{1}$ and P. Roger ${ }^{1}$
}

\section{Introduction}

$\mathrm{T}$

he obvious importance of nitrogen $(\mathrm{N})$ availability for eucalypt growth in a nitrogen-poor environment required determining if biological nitrogen fixation (BNF) was occurring. Microbial activity in eucalypt plantations was expected to be strongly reduced by the well known allelopathic effect of the litter (Souto et al. 1995; Bernhard-Reversat 1999).

Simple acetylene reducing activity (ARA) measurements provide a qualitative estimation of the actual soil $\mathrm{N}_{2}$ fixing activity (Roger and Ladha, 1992). The addition of glucose is generally used to estimate their $\mathrm{N}_{2}$ fixing potential (expressed when $\mathrm{C}$ substrates are not limiting). Indeed ARA in the presence of glucose is also an index of the abundance of free-living $\mathrm{N}_{2}$-fixing microorganisms in the soil. O'Connell and Grove (1987) found some ARA in the litter of Australian native eucalypt forests. Although the amount of $\mathrm{N}_{2}$ fixed extrapolated from these measurements was low, BNF could be a relatively significant source of nitrogen in the nitrogen-poor soil of the eucalypt plantations. Crews et al. (2000), also using ARA measurements, reported very low BNF values ranging from 0.05 to $1.25 \mathrm{~kg} \mathrm{ha}^{-1}$ year ${ }^{-1}$ in the leaf litter of Metrosideros polymorpha in Hawaii. The aim of this study was to assess the impact of the different methods of exploitation on the $\mathrm{N}$ fertility of the surface of tropical soils planted with eucalypts in Congo. The ARA method (Hardy et al. 1968) was used.

\section{Material and Methods}

\section{Samples}

A first series of composite core samples (4 subsamples) was collected in the first $5 \mathrm{~cm}$ of the profile. Four composite samples were collected in savanna and in each of the age series of eucalypt plots (Ep, Er, Et and Eu). Litter samples were separated from the soil with forceps, except for the savanna samples where no litter was present (Table 5.1).

A second series of 12 litter samples originating from the 19-year-old first rotation crop and coppice plots were used (Et and Eu). Litter alone was sampled because none of the previous soil samples exhibited ARA.

\section{ARA measurements}

Acetylene reducing activity (Hardy et al. 1968) was estimated on the basis of the acetylene/ ethylene pic area ratio, assuming no significant change of the acetylene concentration in the flasks. This method of calculation is valid for a consumption of less than $1 \%$ of the acetylene introduced (which was the case in all measurements performed) and has the advantage of being independent of the gas pressure within

1 Laboratoire IRD de Microbiologie, Université de Provence, ESIL, Case 925, 163 Avenue de Luminy 13288, Marseille Cedex 9, France. 
Table 5.1 First series of samples for ARA measurements

\begin{tabular}{llcccc}
\hline Plot & Stand type & $\begin{array}{c}\text { Plot age } \\
(\mathrm{yr})\end{array}$ & $\begin{array}{c}\text { Sample } \\
\text { harvested }\end{array}$ & Times & $\begin{array}{c}\text { Number of } \\
\text { sample }\end{array}$ \\
\hline $\mathrm{Ep}$ & Seedling & 6 & Litter & 0 & $1-4$ \\
$\mathrm{Ep}$ & Seedling & 6 & Soil & 0 & $1-4$ \\
$\mathrm{Er}$ & Coppice & 13 & Litter & 1 & $9-12$ \\
$\mathrm{Er}$ & Coppice & 13 & Soil & 1 & $9-12$ \\
$\mathrm{Eu}$ & Seedling & 19 & Litter & 0 & $13-16$ \\
Eu & Seedling & 19 & Soil & 0 & $13-16$ \\
Et & Coppice & 19 & Litter & 2 & $17-20$ \\
Et & Coppice & 19 & Soil & 2 & $17-20$ \\
\hline Savanna & - & - & Soil & - & $5-8$ \\
\hline
\end{tabular}

the flask and from eventual leakages. Acetylene and ethylene were measured in a FID Varian chromatograph.

\section{Experimental protocols}

\section{First experiment}

Soil and litter incubations were performed in $60 \mathrm{ml}$ flasks at $30^{\circ} \mathrm{C}$. Soils samples $(15 \mathrm{~g})$ and litter samples $(5 \mathrm{~g})$ were brought to water retention capacity by the addition of $1.5 \mathrm{ml}$ and $5.8 \mathrm{ml}$ water, respectively. Samples were incubated for one day in open flasks. Then the flasks were closed with a rubber stopper and $10 \mathrm{ml}$ acetylene was injected with a syringe in each flask. As ARA measurements performed daily for five days showed no significant activity, flasks were opened, ventilated to replace the flask atmosphere, $2 \%$ glucose was added, then the flasks were closed and $10 \mathrm{ml}$ acetylene was again injected. ARA measurements were performed daily for four days and then after 15 days of incubation.

\section{Second experiment}

A second series of measurements was performed on all litter samples, which were first incubated in open flasks for five days, then enriched with $2 \%$ glucose before performing daily ARA measurement for four days

\section{Third experiment}

A second series of 12 litter samples originating from the 19-year-old first rotation crop and coppice plots was tested. Results showed no ARA both in the absence and in the presence of $2 \%$ glucose.

In order to check the potential inhibitory effect of the eucalypt litter on ARA and $\mathrm{N}_{2}$-fixing micro- organisms we conducted an experiment with a temperate calcareous garden soil having received no agro-chemicals. The soil was treated as previously indicated and received the four combinations of two treatments : $2 \%$ glucose : + and -; eucalypt litter extract : + and -. The eucalypt litter extract was prepared by blending $20 \mathrm{~g}$ of litter (second set of litter samples) in $20 \mathrm{ml}$ water, magnetic stirring for 1 hour, followed by filtration. The extract was used straight after its preparation.

\section{Results}

In the first experiment (first set of samples), samples tested daily for five days with no glucose added showed no ARA. Six of the 36 samples where glucose was subsequently added, exhibited ARA. All were litter samples. Only data dealing with samples exhibiting significant ARA are presented in Table 5.2.

In the second experiment (first set of samples), only four litter samples collected in two of the plots which had significant ARA in the first experiment, showed ARA ranging from 5 to $75 \mu$ moles $\mathrm{g}^{-1} \mathrm{~h}^{-1}$. Samples exhibiting significant ARA are presented in Table 5.3.

In the third experiment (second set of samples), none of the 12 litter samples exhibited ARA in the absence or in the presence of $2 \%$ glucose. Samples of temperate garden soil without glucose addition had no ARA. Samples of temperate garden soil receiving $2 \%$ glucose exhibited ARA values ranging from 198 to $367 \mu$ moles $\mathrm{C}_{2} \mathrm{H}_{4} \mathrm{~g}^{-1} \mathrm{~h}^{-1}$. The addition of eucalypt litter extract resulted in a significant inhibitory effect (33\%). Only samples of the temperate garden exhibiting significant ARA are presented in Table 5.4. 
Table 5.2 ARA in litter samples incubated with glucose added: first experiment

\begin{tabular}{lcc}
\hline $\begin{array}{l}\text { Plot and } \\
\text { sample }\end{array}$ & $\begin{array}{c}\text { Number of } \\
\text { sample }\end{array}$ & $\begin{array}{c}\text { ARA } \\
\left(\mu \text { moles } ~ g^{-1} \mathrm{~h}^{-1}\right)\end{array}$ \\
\hline Ep, litter & 1 & $61^{*}$ \\
Ep, litter & 4 & 88 \\
Er & 11 & 73 \\
Et & 17 & 55 \\
Et & 18 & 80 \\
Et & 19 & 54 \\
\hline
\end{tabular}

${ }^{*} \mathrm{C}_{2} \mathrm{H}_{2}$ production stopped after 50 hours

Table 5.3 ARA in litter samples incubated with glucose added: second experiment

\begin{tabular}{lcc}
\hline Plot & $\begin{array}{c}\text { Number of } \\
\text { sample }\end{array}$ & $\begin{array}{c}\text { ARA } \\
(\mu \text { moles g }\end{array}$ \\
\hline Ep & 4 & 75 \\
Et & 17 & 20 \\
Et & 18 & 60 \\
Et & 20 & 5 \\
\hline
\end{tabular}

Table 5.4 ARA of temperate garden soil samples with or without addition of eucalypt litter extract

\begin{tabular}{cccc}
\hline $\begin{array}{c}\text { Number of } \\
\text { sample }\end{array}$ & Glucose & $\begin{array}{c}\text { Litter } \\
\text { extract }\end{array}$ & $\begin{array}{c}\text { ARA } \\
\left(\mu \text { moles } ~^{-1} \mathrm{~h}^{-1}\right)\end{array}$ \\
\hline 4 & + & - & 367 \\
5 & + & - & 347 \\
6 & + & - & 245 \\
11 & + & + & 198 \\
12 & + & + & 235 \\
13 & + & + & 217 \\
\hline
\end{tabular}

\section{Discussion and Conclusions}

As no significant ARA was observed with soils, even those enriched with $2 \%$ glucose, it is concluded that $\mathrm{N}_{2}$-fixing activity was absent and there is no significant potential for BNF should an easily usable carbon source become available. No significant ARA was observed with litter incubated without additional source of carbon. Some litter exhibited ARA ranging from 5 to 90 $\mu$ moles $\mathrm{C}_{2} \mathrm{H}_{4} \mathrm{~g}^{-1}$ soil $\mathrm{h}^{-1}$ when enriched with $2 \%$ glucose. These values are of the same order of magnitude than those observed by Knowles et al. (1973) using a sandy soil enriched with glucose (34 to $51 \mu$ moles $\mathrm{C}_{2} \mathrm{H}_{4} \mathrm{~g}^{-1}$ soil $\mathrm{h}^{-1}$ ). Some other reported values (Granhall 1978) are listed for comparison in Table 5.5.

Among 36 samples studied in the Congolese plantations, only the litter of the 19-year-old coppice (samples 17, 18, 19 and 20) showed significant $\mathrm{N}_{2}$-fixing activity in the four replicates. In the 7-year-old forest, one litter sample among four exhibited a significant ARA on both measurements. In the 13-year-old coppice, only one sample exhibited ARA on the first measurement. The savanna soil has apparently no actual or potential $\mathrm{N}_{2}$-fixing activity. Indeed, measurements of ARA in the rhizosphere of various plants in the different ecosystems is needed before drawing any conclusion. However, the third experiment definitely indicates an inhibitory effect on BNF of the hydrosolubles present in the eucalypt litter. The litter of the 19-year-old coppice, which showed most frequently ARA in the above experiments also had the lowest content in soluble phenolic compounds (cf. chapter 3 ). Results confirm the previously reported inhibitory effect of eucalypts on soil microbial activities. The poor ability of crop residues rich in phenolics to support heterotrophic BNF was also reported by Gibson et al. (1988). The occurrence of BNF in Australian forests (O'Connell and Grove, 1987) suggests that soil microflora could be more adapted to eucalypt in their native area. Also free-living $\mathrm{N}_{2}$-fixers might be more sensitive to the inhibitory effect of eucalypt litter than symbiotic $\mathrm{N}_{2}$-fixers, as no inhibition of symbiotic BNF was observed in mixed-species stands of Eucalyptus robusta with either Casuarina equisetifolia or Leucaena leucocephala (Parrotta et al. 1996).

Table 5.5 Other ARA values from soils (Granhall 1978)

\begin{tabular}{lcc}
\hline Site & Glucose & $\begin{array}{c}\text { ARA } \\
\left(\mu \text { moles g- } \mathrm{h}^{-1}\right)\end{array}$ \\
\hline Lake sediment & & $0.02-0.3$ \\
Rice soils incubated & - & $10-70$ \\
Temperate soil (Sweden) in pine forest: litter & - & 0.5 \\
Temperate soil (Sweden) in pine forest: soil Ao & - & 0.08 \\
Temperate soil under various plants & - & 0 \\
Temperate soil under various plants & + & $1-100$
\end{tabular}

Incubations were made with (+) or without (-) glucose added. 


\section{Chapter 6.}

\section{Effect of Exotic Tree Plantations on Free Living and Plant Parasitic Soil Nematodes and Population Changes with Eucalypt Hybrids and Plantation Age}

P.M. Loubana ${ }^{1}$ and G. Reversat ${ }^{2}$

\section{Introduction}

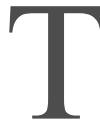

he effect of changing environment on microfauna in plantations compared to savanna was studied for free-living and plant parasitic nematode populations. The first are of importance in the micro-food web, and although little is known about it, change in organic matter quality is assumed to affect their populations. The populations of plant parasitic nematodes, which are bound to one or several host plants, are expected to be influenced by the new planted and undergrowth species and by the disappearance of savanna species. Thus if planted eucalypts were host-plants for one of the native plant parasitic nematode species, population densities of this parasite could increase and their possible pathogenic effect on the crop should be considered.

Knowledge of nematodes associated with the eucalypts' rhizosphere in natural environments and in plantations is very limited, according to Majer et al. (1997), who mentioned nematodes as the most numerous animal class in the soil but did not quote any references on this topic. In eucalypt plantations in the Congo, a qualitative approach showed two species of plant parasitic nematodes belonging to the genus Xiphinema (Family: Longidoridae) as parasites of eucalypt roots: $X$. parasetariae and $X$. souchaudi (Baujard et al. 1998).

The words "nematode" and "eucalypt" can be found linked very often in bibliographic data bases. This is related to the permanent quest for nematicidal properties of natural substances among plants, including eucalypts, and the need to reduce the use of synthetic chemical nematicides for environmental considerations. However, such studies were not concerned with nematode parasites of eucalypt roots.

The study had two aims: (i) to assess the changes in species distribution and population densities of nematodes associated with changes in plant cover; (ii) to study a possible pathogenic effect of these changes on the eucalypt crop.

\section{Studied Plots and Methods}

\section{Field studies}

The study of nematodes was first carried out in the age series of the Pointe-Noire savanna and experimental plantations ( $\mathrm{Sa}, \mathrm{Ea}, \mathrm{Ed}, \mathrm{Ee}, \mathrm{Ef}$ ) and the Loudima savanna and plantations (SL, El, AL, PL, Table 0.2). Three to five composite soil samples were extracted along one or two transects across each plot. Composite samples resulted from five soil cores ( 0 to $15-20 \mathrm{~cm}$ depth) taken $15 \mathrm{~cm}$ away from the trunk of every other planted eucalypt tree. A second sampling series in the commercial plantations (second project, Table 0.3 )

\footnotetext{
Laboratoire de Nématologie, Centre IRD de PointeNoire, B.P. 1286, Pointe-Noire, Congo.

2 Laboratoire d'Ecologie des Sols Tropicaux, Centre d'Ile de France, 32 avenue Henri Varagnat, 93143 Bondy, France.
} 
aimed to study the distribution pattern of nematodes in savanna (Sb), in E. PF1 plots (Ep, $\mathrm{Er}, \mathrm{Et}, \mathrm{Eu})$ and in the 8-9-year-old multiclonal plot where $E$. urograndis was studied (Ev). Due to the transect method, in this last plot, the sampled transect crossed several clones and hybrids. Soil cores were made on tree lines at every other tree. This resulted in 10 to 20 samples on each sampled tree line, beginning on the plot edge. Samples were taken $1 \mathrm{~m}$ away from the trunks, and cores were $15 \mathrm{~cm}$ depth, with a soil volume of $424 \mathrm{ml}$. Nematodes were extracted from soil by the twoflask technique (Seinhorst 1955) and from roots by the mistifier extraction technique (Seinhorst 1950). All individuals of each species of plant parasitic nematodes were counted, and neither genera nor species were determined for free-living nematodes. Plant parasitic nematodes extracted from roots were very scarce, whereas free-living nematodes extracted from roots were sometimes very numerous. According to the short life-cycle of free-living nematodes (4-7 days), and the time required for an efficient recovery of plant parasitic nematodes from roots through the mistifier ( 2 weeks), these free-living nematodes were assumed to multiply on the roots during mistifying. Therefore data on free-living nematodes extracted from roots were not included in the results. The frequency was calculated as the ratio of the number of samples containing nematodes to the total number of samples expressed as a percentage. Root weight was measured for each sample.

\section{Laboratory study of eucalypt clone susceptibility to Xiphinema parasetariae}

The susceptibility of eucalypts to Xiphinema parasetariae, the major plant parasitic nematode found in the eucalypt plantations, was assessed in the laboratory. Young cuttings were planted in PVC vessels (one cutting per vessel) with $500 \mathrm{ml}$ of heat-sterilised savanna soil (maintained for 10 hours at $75^{\circ} \mathrm{C}$ ). Each plant was inoculated with 10 nematodes and the vessels were kept at $30^{\circ} \mathrm{C}$ in a temperature-controlled box. Nematodes were extracted from each vessel after three months. The final population was obtained by addition of the Xiphinema extracted from soil and from roots, and the reproduction rate was calculated as the ratio final population/initial inoculum. The experiment comprised four replications for each clone.

\section{Results and Discussion}

Two great groups of soil nematodes were considered, free-living and plant parasitic, because of the different ways in which their populations could change. The second group is linked to the occurrence of host plants although these plants are not always known. The mean number of individuals of the two groups of soil nematodes was calculated (Table 6.1), and eventually compared to the vegetation characteristics.

\section{Free living nematodes}

Free-living nematodes were more numerous in savannas than in plantations. In plantations a significant correlation ( $\mathrm{r}=0.733$ for 12 plots) was observed with the percentage of savanna plant species (as defined in chapter 1 ) in the vegetation which is an index of environment change. It suggested that the savanna populations of nematodes were disappearing while those of the forest had not yet stabilised, and indicated that there were no differences due to the planted tree species. Consequently, although an increase of nematode number with increasing carbon content is generally reported (Yeates 1979; Pradhan et al. 1988), no significant relationship occurred in the studied plantations. Taking into account the data of the first project, a negative relationship between the number of free-living nematodes and the macrofauna biomass (expressed as $\log , \mathrm{r}=-0.915$ $\mathrm{p}=0.1 \%$ Fig. 6.1 ), which is largely dominated by earthworms, could indicate an antagonistic effect. However this hypothesis deserves more study because this relationship could also result from the effect of litter or organic matter quality. The density of free-living nematodes was lower in the second sampling series in commercial eucalypt plantations than observed in the experimental plots, and in the commercial plantations, their density was higher in the old $E$. PF1 plots than in the younger plots $(p=0.02)$. There was no significant difference between the first rotation crop and coppice. The comparison between the sandy soil (Pointe-Noire) and the clay soil (Loudima), showed a trend towards a higher density of free-living nematodes in sandy soil under savanna (Table 6.1), whereas this was less obvious under eucalypt and acacia plantations 
Table 6.1 Average density (number of individuals litre ${ }^{-1}$ of soil) of free-living and plant parasitic nematodes in savanna and eucalypt plantations at Pointe-Noire and Loudima

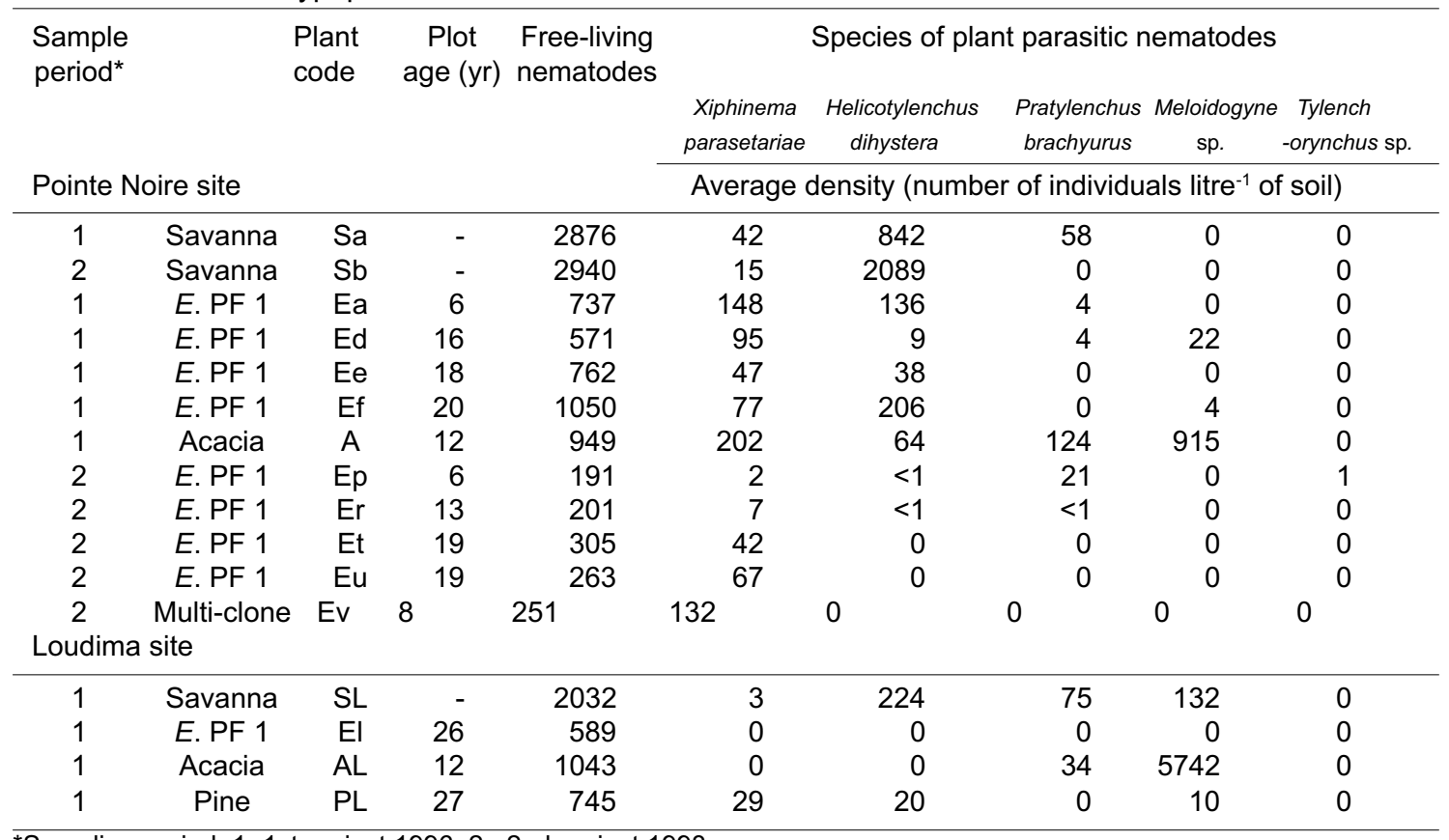

*Sampling period: 1=1st project 1996, 2= 2nd project 1998.

Figure 6.1 Relationship between free living nematode density and macrofauna fresh biomass in plantations and savanna

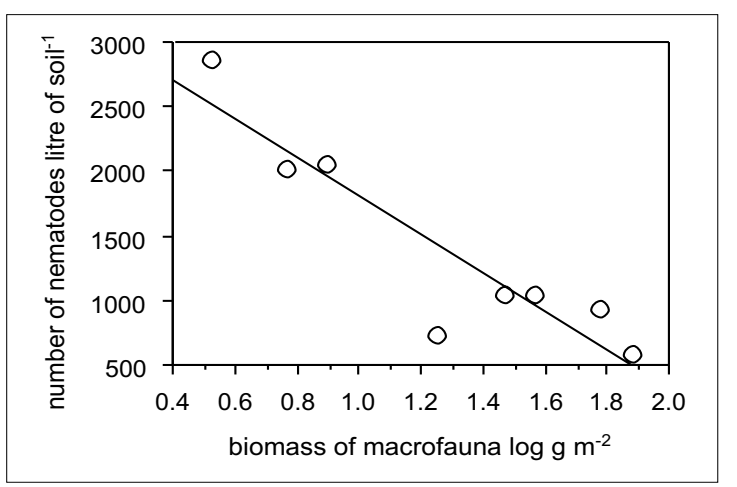

because of other constraints. The chemical effect (inactivation of organic compounds) and physical effect (porosity) of clay were assumed to affect nematode populations (Fargette 1987; Groethals 1987).

The drastic decrease in free-living nematode density in the soils of plantations compared to savanna could be explained by the effect of the cover-crop tillage, which was made to $20 \mathrm{~cm}$ depth, and might result in a more exhaustive drying than nematodes were able to survive, especially if the plot was tilled during the dry season. However, tillage did not affect the density of bacterialfeeding nematodes in a semi-arid Mediterranean agrosystem (Lopez-Fando and Bello 1995). Lifecycles of microbivorous nematodes, which are the main part of the free-living nematode populations, are rather short (4-7 days) and the reproduction rate is high (Nicholas 1975). Therefore the recovery of the initial population density could be easily achieved within one rainy season (8-9 months). The decrease in density could be better explained by a change in the microbial status of soil resulting from the disappearance of root exudates from grasses and the input of eucalypt litter essential oils ( $\mathrm{Li}$ and Madden 1995) or polyphenols (Conde et al. 1997) which have antibiotic activity. A decrease in microbial biomass could result in a shortage of food for free-living nematodes, since most of them are microbivorous. Acacia auriculiformis litter was poorer in phenolic compounds than eucalypt litter (BernhardReversat 1999) and more free-living nematodes were found in soil under acacias than in soil under eucalypts. Moreover, some chemical compounds of eucalypt litter could exhibit a direct antinutritional effect on nematodes as has been already observed on soil detritivore arthropods (Maity and Joy 1999). 
Whatever the origin of the decrease in density of free-living nematodes, it affected soil functioning because nematodes are known to have an active part in several soil processes, as microbial activity, organic matter decomposition and nitrogen mineralisation (Pradhan et al. 1988; Ferris et al. 1998). However the status of soil environment would be assessed more accurately if free-living nematode populations were studied at the generic level (Porazinska et al. 1999).

\section{Field study of plant parasitic nematodes}

\section{Eucalypt plantations}

Eucalypts were planted as cuttings grown in artificial substrate so that the cuttings could not have been infected with nematodes. Infection was assumed to spread from nematodes living on savanna host plants and to develop when they found a host plant in the plantations. Six species of plant parasitic nematodes were found in eucalypt plantations: Xiphinema parasetariae, $X$. souchaudi, Helicotylenchus dihystera, Pratylenchus brachyurus and Tylenchorhynchus sp. The only abundant species was $X$. parasetariae, for which eucalypt is a host plant, as was demonstrated by experimental inoculation in the laboratory. Xiphinema souchaudi also parasitises eucalypts but remained scarce in the plantations (Baujard et al. 1998). Xiphinema parasetariae and $X$. souchaudi were located in the $0-30 \mathrm{~cm}$ layer of soil and during the dry season, from June to September, they survived soil desiccation. Both species were shown to be able to enter in anhydrobiosis (Reversat 1996). The other three species were scarce and were assumed to parasitise undergrowth plant species. Helicotylenchus sp. alone was more abundant in savanna than in plantations. Its host plant was assumed to be a savanna species and to disappear with the aging of plantations (Huttel and Loumeto, chapter 1), resulting in the decrease or disappearance of $H$. dihystera in plantations (Goede et al. 1993).

Xiphinema parasetariae predominated in the plantations studied (Table 6.1). However the density of $X$. parasetariae in the young experimental plantations was higher than that of the commercial areas and this may be due to different silvicultural practices. The numerous samples made in the commercial plantations
Figure 6.2 Density of free-living nematodes in savanna and eucalypt plantation plots

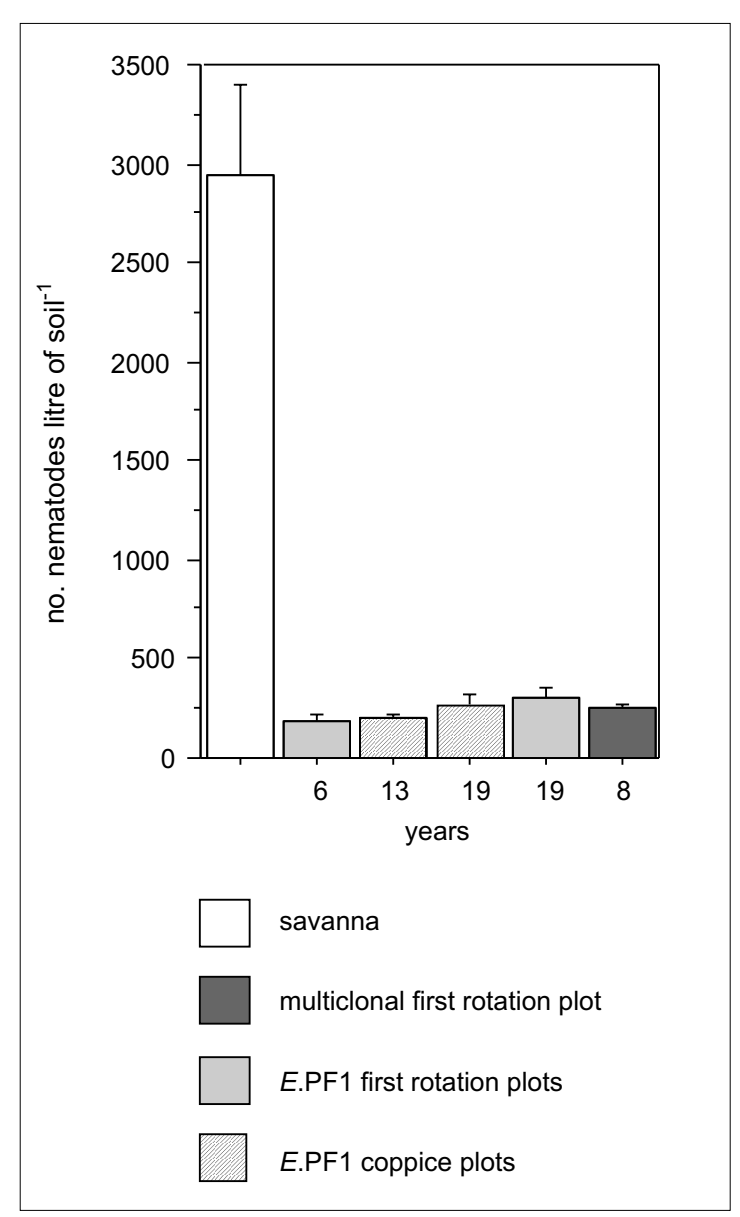

Figure 6.3 Density of Xiphinema parasetariae in savanna and eucalypt plantation plots

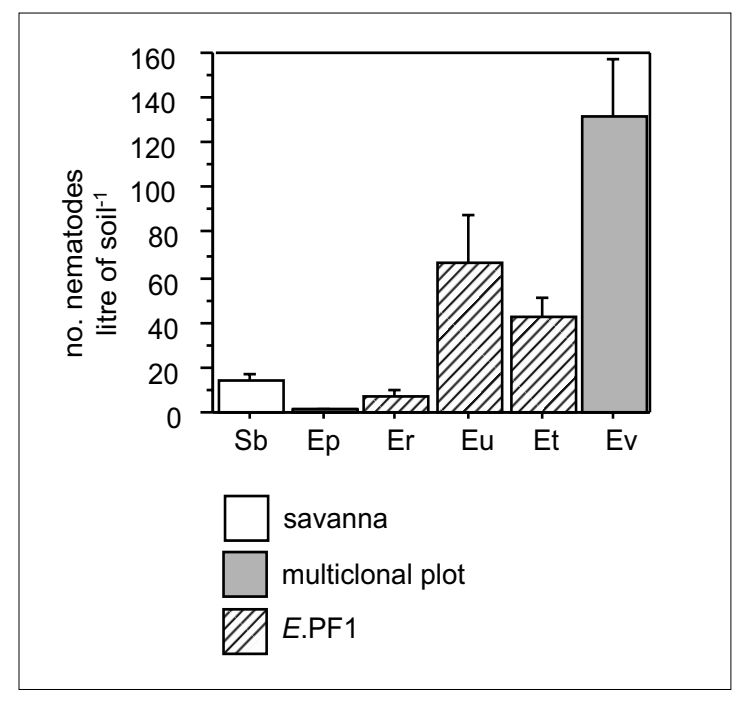


during the second project allowed the study of the distribution of $X$. parasetariae in the $E$. PF1 plots. Differences among plots in density and frequency of $X$. parasetariae were highly significant $(p=0.0001$, Fig. 6.3). Along the sampled transect, patches of samples with zero nematodes separated patches of positive samples. The estimation of the average length of positive patches was significantly correlated $(\mathrm{p}=0.001)$ with plot age (Loubana and Reversat, in preparation).

Another distribution pattern of $X$. parasetariae was observed in the 8-year-old multiclonal plantation, where it was widely spread, with a higher density than in the 6-year-old $E$. PF1 plot. Xiphinema development is dependent on the number of root apices, and root density in the sampled cores was significantly higher in the multiclonal plot (0.26 $\mathrm{g} \mathrm{sample}^{-1}$, standard error $0.01)$ than in the 6-year-old $E$. PF 1 plot $(0.11 \mathrm{~g}$ sample $^{-1}$, standard error 0.005$)$, due to closes spacing (666 trees ha-1 and 532 trees ha ${ }^{-1}$ respectively). The hypothesis of the control of Xiphinema by root apex density will be investigated in further studies.

The high densities of $X$. parasetariae found in old eucalypt plantations could be high enough to affect the trees, and especially the seedlings at the time of replanting. This nematode attacks the root apex and might prevent a normal root growth (Wallace 1973). The resulting wounds enable the infestation of the plant by bacteria and fungi and could be responsible for low vigour in young plantations. However few data are available on the specific effect of Xiphinema spp. on eucalypt growth, although this nematode genus was found in South African eucalypt plantations by Marais and Buckley (1993). It was also reported on young Pinus caribaea in Nigerian plantations (Gbadegesin 1993). Xiphinema elongatum was shown to be harmful for sugar cane crops planted on infested soil previously under eucalypt plantation (Spaull 1998).

\section{Acacia plantations}

Meloidogyne spp. were the most abundant plant parasitic nematodes encountered under acacia, which is a host plant for them. Meloidogyne did not occur in savanna around Pointe-Noire, and this might be related to the inability of this genus to withstand desiccation during the dry season.
Figure 6.4 Comparison of the reproduction rates of Xiphinema parasetariae on eight eucalypt clones

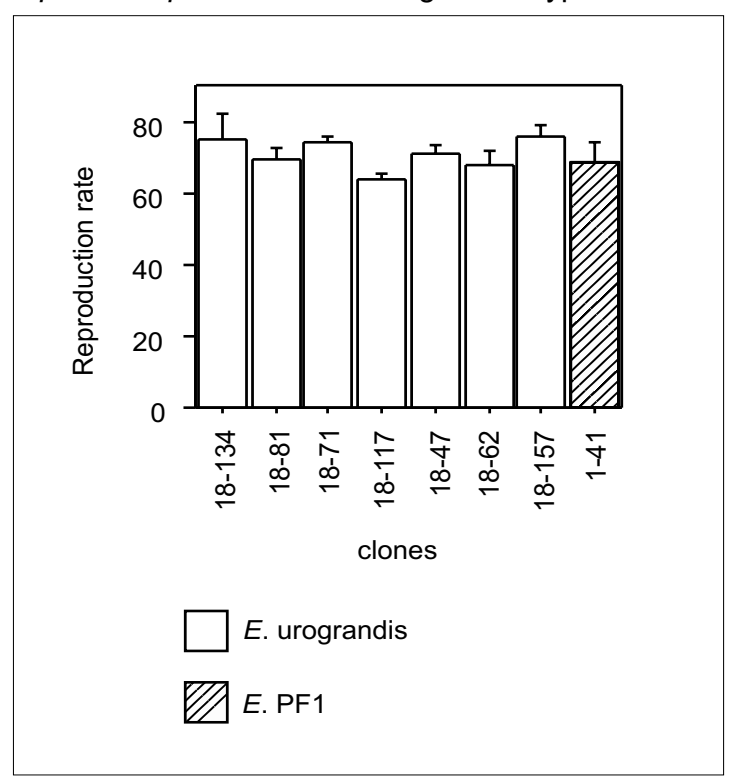

Acacia plants might have been infested by Meloidogyne in the nursery from soils from vegetable crop areas used as a potting mix, most of which are highly contaminated with Meloidogyne (Loubana 1996). Xiphinema spp. were also abundant under acacia which is a good host plant, and the contamination might have occurred from the savanna populations, as in eucalypt plantations.

\section{Laboratory study on clone susceptibility to Xiphinema parasetariae}

The test for clone susceptibility showed the reproduction rates of Xiphinema parasetariae were very similar among the eight studied clones (Fig. 6.4), and the ANOVA was not significant. However when the ANOVA was made without the three most variable clones, it was significant for the five other clones $(\mathrm{p}=0.04)$ and some clones appear to be less sensitive. It could be interesting to test a greater number of clones. However, the low genetic variability of eucalypt hybrids suggested that resistant clones could not be found, and plant resistance to the genus Xiphinema was very rarely found (Luc and Reversat 1985). 


\section{Conclusions}

Dramatic changes in nematode populations occurred when eucalypt trees were planted on savanna. Population densities of free-living nematodes decreased drastically to one tenth of their initial values, from several thousand individuals per litre of soil in savanna to several hundred of individuals per litre of soil in 6-yearold eucalypt plots. During the same time, the biodiversity of plant parasitic nematodes was reduced from savanna (five genera) to eucalypt plots (only one genus, Xiphinema) and the density of the main species, $X$. parasetariae, increased in the eucalypts.

Much remains to be done concerning the functional groups of free-living nematodes and their role in soil functioning. A more careful approach during the early stages (between the beginning and 5 years) of eucalypt plantation establishment is needed. The investigations should focus on the variation of the free-living nematode population and an evaluation of the soil microbial biomass, of which a part is consumed by freeliving nematodes.

The plant parasitic nematode populations are better known, because their taxonomical status is very simple. Until now, only two species have been demonstrated as parasites of eucalypt roots in Congo: Xiphinema parasetariae and X. souchaudi. Their densities were found to be as high as 150 individuals per litre of soil in eucalypt plots, and the possible detrimental consequence of this infestation on the functional status of roots and the growth of trees deserves further study. 


\title{
Chapter 7.
}

\section{Effect of Exotic Tree Plantations on Invertebrate Soil Macrofauna}

\author{
I.M.C. Mboukou-Kimbatsa ${ }^{1}$ and F. Bernhard-Reversat ${ }^{2}$
}

\section{Introduction}

$\mathrm{T}$ he effect of plantations on plant biodiversity was discussed by Parrotta (1993) and for the studied plantations by Huttel and Loumeto (see chapter 1). Vegetation is known to influence the trophic chain and soil fauna in particular (Lavelle et al. 1994). Soil invertebrates carry out essential functions for soil functioning, specifically soil organic matter decomposition, soil aggregate formation, and soil mixing allowing the activation of micro organisms (Lavelle et al. 1997). Vegetation change is expected to affect macrofauna (Abbott et al.1999; Vohland and Schroth 1999; Gonzales and Seastedt 2000) and degraded lands generally undergo a decrease in soil fauna density and diversity (Tian 1998). In order to assess the effect of growing exotic trees on savanna soils, soil macrofauna was studied among plots of various ages, species, hybrids and management practices.

\section{Studied Plots and Methods}

Soil macrofauna was studied in the Pointe-Noire age series plots of the first project ( $\mathrm{Sa}, \mathrm{Ea}, \mathrm{Eb}, \mathrm{Ec}$, Ef, F Table 0.2), in Loudima plots (EL, AL, PL, SL, Table 0.2.) and in plots of the second project (Ep, Eq, Er, Es, Et, Eu, Ev, Ew, Sb, Table 0.3). Only $E$. urograndis was sampled in the two last multiclonal plots.

Soil macrofauna was sampled according to the Tropical Soil Biology and Fertility Programme method (Anderson and Ingram 1993). In each plot, 10 samples were taken $5 \mathrm{~m}$ apart along a randomly chosen transect. Each sample was a column of soil $30 \mathrm{~cm}$ deep and $25 \times 25 \mathrm{~cm}$ square. Columns were separated into four layers: litter, 0-10 cm, 10-20 $\mathrm{cm}$ and $20-30 \mathrm{~cm}$. Samples were hand-sorted in a large flat dish, and all visible invertebrates were placed in $85^{\circ}$ alcohol and then in a $4 \%$ formol solution for conservation. They were counted and weighed. To take into account weight loss due to alcohol or formalin, corrections for fresh weight were applied (Anderson and Ingram 1993). Organisms were not identified to species and only the main taxa were considered. These taxa were gathered together in the following groups: earthworms, termites, ants, and litter inhabiting animals.

\section{Results and Discussion}

\section{Changes with vegetation and soil}

Densities of earthworms, termites and litter animals were significantly different between plots whereas ants were present everywhere and did not show significant differences (Fig. 7.1). However, because density data are highly variable, the relationships between vegetation and frequency

\footnotetext{
1 Laboratoire d'Écologie, Centre IRD de Pointe-Noire, B.P. 1286, Pointe-Noire, Congo.

2 Laboratoire d'Ecologie des Sols Tropicaux, Centre IRD d'Ile de France, 32 avenue Henri Varagnat, 93143 Bondy, France.
} 
Figure 7.1 Density (number $\mathrm{m}^{-2}$ ) and biomass $\left(\mathrm{g} \mathrm{m}^{-2}\right.$ ) of the main groups of soil macrofauna in fast growing tree plantations and natural ecosystems

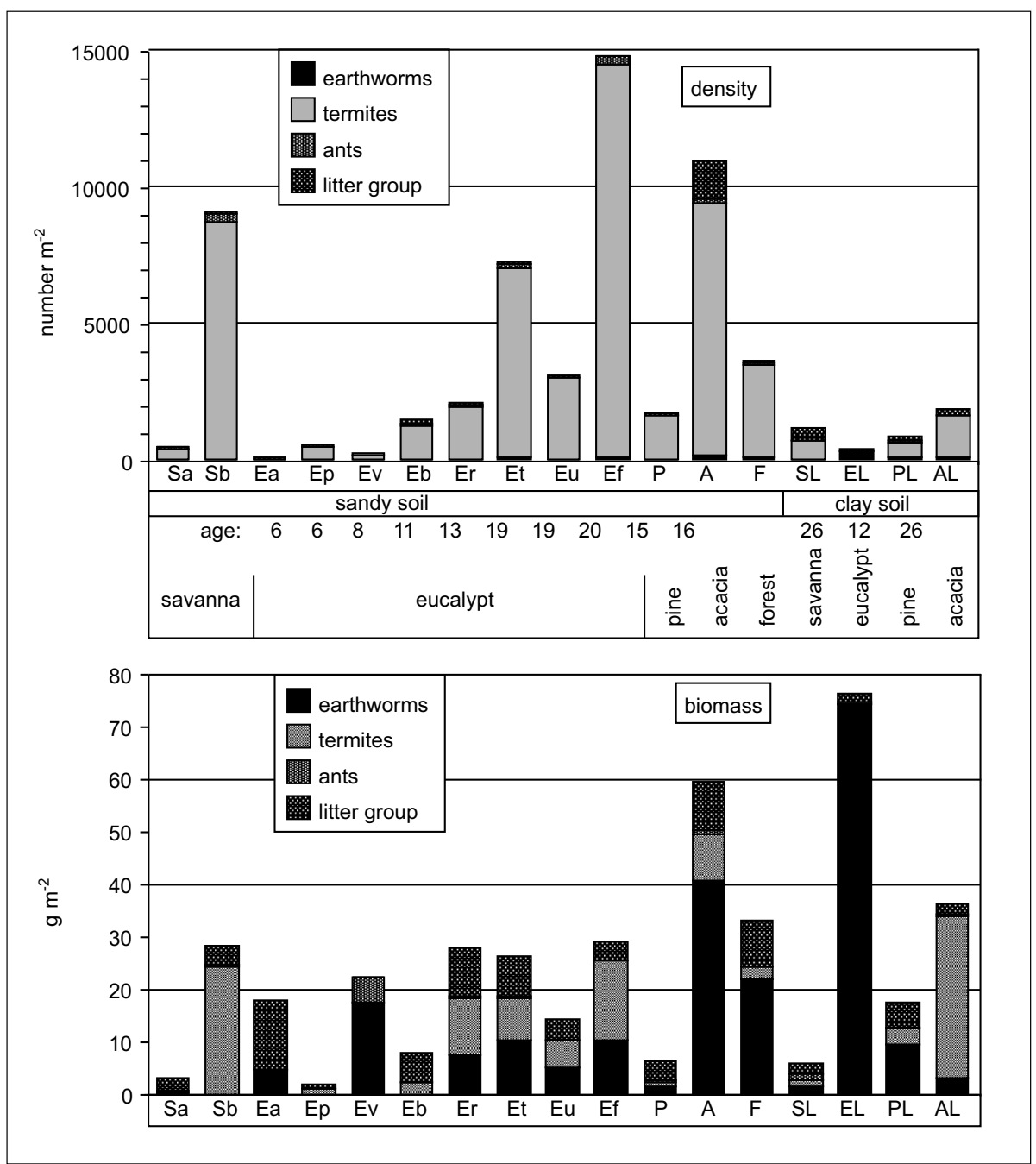

See Tables 0.2 and 0.3 for plot codes. The plot age is given in years. Sandy soils are near Pointe-Noire, clay soils are near Loudima. 
Figure 7.2 Frequency of the groups of soil macrofauna taxa in fast growing tree plantations, savanna and forest plots

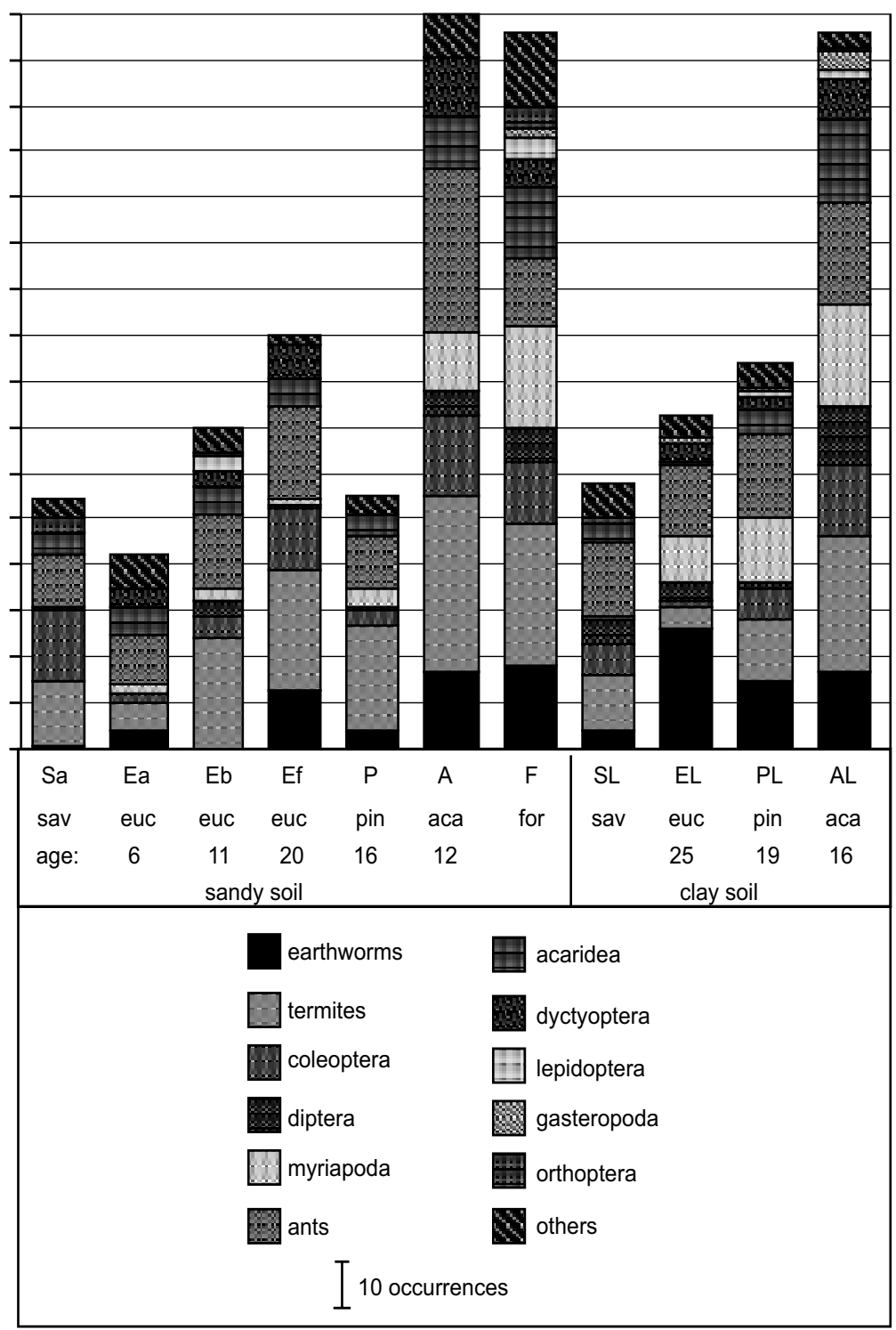

Plot age in years. sav = savanna, euc = Eucalyptus PF1, pin = Pinus caribaea, aca $=$ Acacia auriculiformis, for $=$ natural forest. See Tables 0.2 and 0.3 for plot codes. 
Figure 7.3 Frequency (occurrence of invertebrates in samples) related to the percentage of forest plant species in the understorey vegetation of experimental plantations

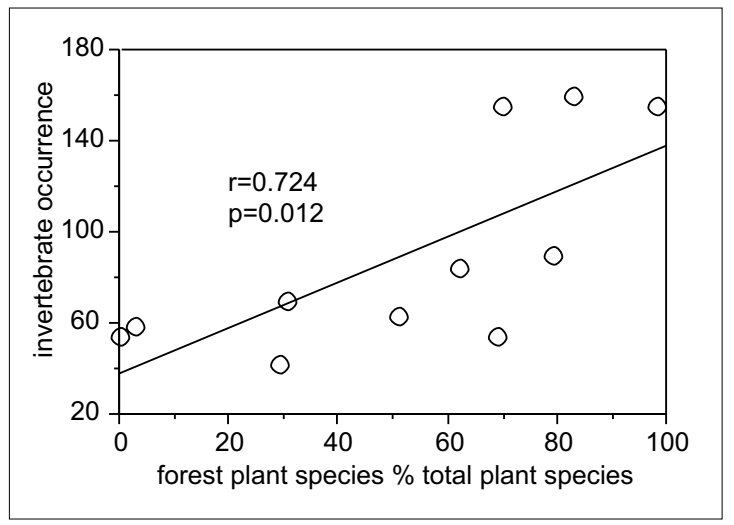

were studied in experimental plantations for the first set of data. The frequency was the number of samples where individuals were found in each 40 samples in one plot (4 layers x 10 replicates) (Mboukou-Kimbatsa et al. 1998). The frequency gives weighted data for the different taxa (Fig. 7.2). Total frequency, as well as the frequency of earthworms, termites, myriapods and cockroaches in eucalypt plantations, was significantly correlated with the vegetation type $(\mathrm{p}=0.01)$, expressed as the percentage of forest plant species in the understorey vegetation (Fig. 7.3). The closer the specific plant composition is to that of a forest, the more the plot is colonised by macrofauna. Several taxa were lacking in savanna, whereas all the counted taxa were well represented in forest. The lack of earthworms in the 11-year-old eucalypt plot might be due to the herbicide treatment that was made one year prior to sampling in this plot. However, the observed frequency in the oldest eucalypt plot (20 years) was far from that of forest. Because frequency is linked not only with the number of individuals, but also with the evenness of their distribution, it seemed to change slower than total biomass, which reached a level close to that of the forest in the 20-year-old plot (Fig. 7.2).

Pine and acacia showed very different results (Fig. 7.2 and 7.3). Pine plantations, like most eucalypt plantations, had poor invertebrate populations, and some taxa were lacking, whereas taxa frequency pattern under acacia resembled that of natural forest. In sandy soils at Pointe-Noire, total biomass was $6.3 \mathrm{~g} \mathrm{~m}^{-2}$ under pine and $59.7 \mathrm{~g}$ $\mathrm{m}^{-2}$ under acacia, this last value being higher than that of the forest $\left(33.1 \mathrm{~g} \mathrm{~m}^{-2}\right)$. In clay soil in Loudima, biomass was 17.6 under pine and 36.3 $\mathrm{g} \mathrm{m}^{-2}$ under acacia. This variation between planted species could be due to the quality of litter and soil organic matter and similar trends were observed for microarthropods (Bernhard-Reversat 1993). It was previously shown that pine litter was very poor in nutrients, particularly nitrogen, and that eucalypt litter was rich in tannins, whereas acacia litter was poor in tannins and rich in nitrogen (Bernhard-Reversat 1996, 1999).

Ants, litter animals and especially termites had higher densities in the savanna plot of the second project than that of the first. For the litter group this difference was mainly due to Coleopterae, and the other litter taxa were absent or scarce in the savanna. The savanna plot in the second study was more fertile and had a greater plant biomass than the previous one, which was very poor. In the two studies, there were no earthworms in savanna. In wet savannas Lavelle et al. (1994) found an average macrofauna biomass of $32 \mathrm{~g} \mathrm{~m}^{-2}$, whereas the biomass was lower in the studied Congolese savanna plots, especially two of them, which had biomass similar to that of drier savanna (Dangerfield 1990). The value for the forest was comparable to the forest average of $21 \mathrm{~g} \mathrm{~m}^{-2}$ given by these authors who pointed out that tree plantations may have higher macrofauna biomass (average $38 \mathrm{~g} \mathrm{~m}^{-2}$ ) than the forest, due to new niches added to the forest population. In a drier environment, a mature Eucalyptus grandis stand showed the same macrofauna biomass (near $10 \mathrm{~g}$ $\mathrm{m}^{-2}$ ) and diversity as the native woodland (Dangerfield 1990). However it was shown that plantations had highly variable results.

Soil type and vegetation are assumed to play a decisive role in the composition of soil population. Regarding the soil/site factor (Fig. 7.2), frequency patterns under acacia and under savanna were surprisingly not very different in the two sites. On the contrary, soil clay content appeared to be related to macrofauna frequency under eucalypt plots, and many earthworms were found in Loudima, resulting in high biomass $\left(74 \mathrm{~g} \mathrm{~m}^{-2}\right)$ and low frequency and number of termites and of most other taxa. Pine plots were too different in age to be compared on a site basis. 


\section{Changes with plantation age}

The changes occurring with age were studied for Eucalyptus PF1 hybrid only. When the results of the two projects were put together the relationships with age were very similar (Fig. 7.4). The high variability of biomass did not result in any clear patterns between biomass and plot age, whereas significant positive regressions with plot age (since it was first planted) were observed for total density $(p=0.0001)$, earthworm density $(p=0.0001)$ and termite density $(\mathrm{p}=0.0001)$. The litter group

Figure 7.4 Change of soil macrofauna densities (number of individuals $\mathrm{m}^{-2}$ ) with eucalypt plot age for the two projects
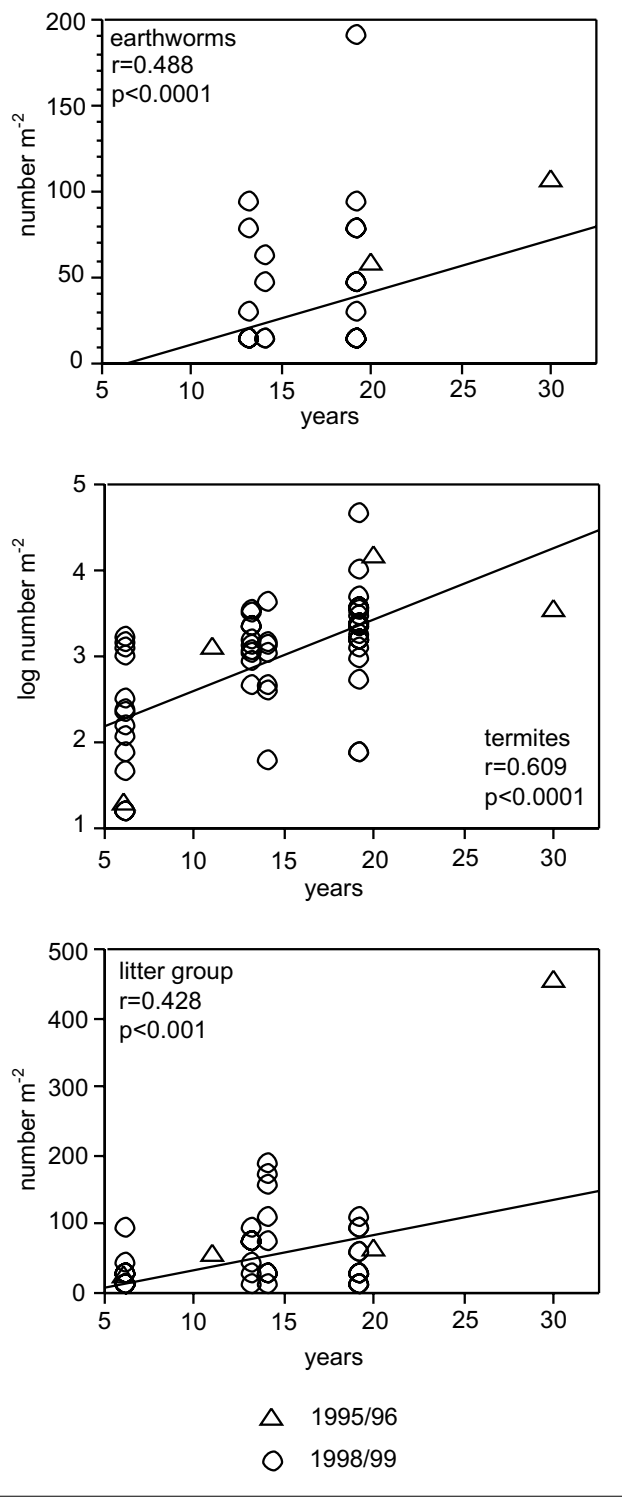

density showed a weaker relationship with age $(p<0.05)$, mainly due to the density of the main component, Coleopterae $\quad(p<0.01)$; Pseudoscorpionidae and Orthopterae increased also. The other litter inhabiting taxa were not abundant enough to show any significant relationships. Vohland and Schroth (1999) found a strong relationship between the amount of litter on ground and the density of soil macrofauna, and the relationship was even stronger with macrofauna biomass. The above observations on increasing earthworm density with age did not accord with the assessment of the disappearance of earthworms under eucalypt plantations by other authors (e.g. Paoletti 1999). However similar observations were made by Zou and Bashkin (1998) who reported a steady increase in earthworm density in eucalypt plantations of increasing age, up to 10 years old, grown on abandoned sugar cane fields free from earthworms; the earlier occurrence of earthworm populations compared to the Congolese plantations could be due to a faster accretion of soil organic matter. In a rubber plantation in Côte d'Ivoire, Gilot et al. (1995) observed an increase in earthworm biomass from 5-year-old plots to 20-year-old plots, followed by a decrease in 30-year-old plots which was attributed to the decrease of mineralisable organic matter. These observations confirm that soil macrofauna is strongly dependent on soil organic matter and litter accumulation.

\section{Changes with management practices}

Clear felled plots were compared with forested plots at 7 years and at 14-15 years (Fig. 7.5). The density of termites was higher in unlogged plots than in harvested plots, although there were great amounts of plant residues on the soil surface in the harvested areas; humivorous termites as well as other termites were affected. Microclimate change and human impact such as harvesting vehicle traffic could have disturbed termite populations. Harvesting decreased termite density but did not seem to affect the other groups.

Coppice was compared to first rotation plantation in the 20-year-old plots and neither density nor biomass was significantly different for any macrofauna groups. Although termite density was decreased by logging this effect might be short-lived, and old coppice stands were not 
Figure 7.5 Effect of eucalypt harvest on termite density

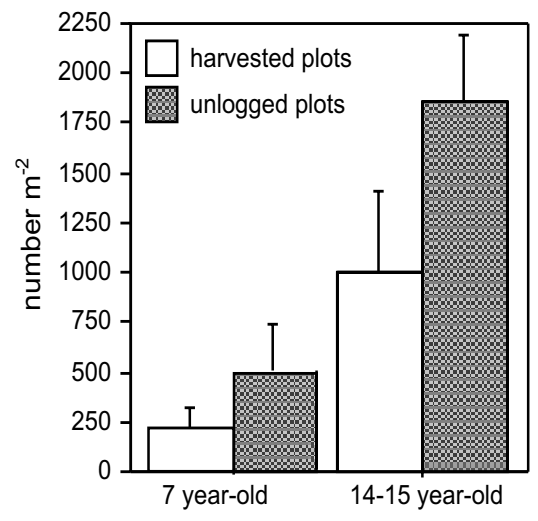

affected. The way wood harvesting is currently undertaken does not prevent the increase of macrofauna populations and consequently the improvement of ecosystem functioning which is expected from it.

\section{Relationships with litter quality}

The amount of more recent litter $(>4 \mathrm{~mm})$ on the soil had rather a negative effect on soil macrofauna density and this relationship was significant for humivorous termites and ants. This relation might be related to litter quality, although our results were based on only five plots and must be confirmed by further studies. The lignin content of fresh litter was negatively correlated with the density of humivorous termites $(\mathrm{p}<0.05)$ and ants $(\mathrm{p}<0.05)$, and soluble phenolic compounds also exhibited a strong negative correlation with termite density $(p=0.001)$ (Fig. 7.6). Termites did not consume fresh litter, but during the rainy season, rain brought soluble phenolic compounds from the fresh litter to the fragmented litter layer below and might therefore decrease food quality for termites, thus controlling termite activity or reproduction. Zou (1993) attributed lower earthworm density in eucalypt plantations compared to albizzia plantations to the lower litter quality in eucalypts. Maity and Joy (1999), observed that mesofauna were not found in eucalypt litter before two months decomposition, unlike in litter of some other species. According to Heal and Dighton (1985), the combined effect of resource quality and physical environment selects microflora, which in turn selects the characteristics of the associated fauna. The effect of phenolic compounds on the feeding behaviour of herbivores is well known (Waterman and Mole 1994; Harborne 1997).

Figure 7.6 Relationships between macrofauna density (number $\mathrm{m}^{-2}$ ) and eucalypt fresh litter quality: lignin and soluble phenolic compounds (percent litter dry weight)
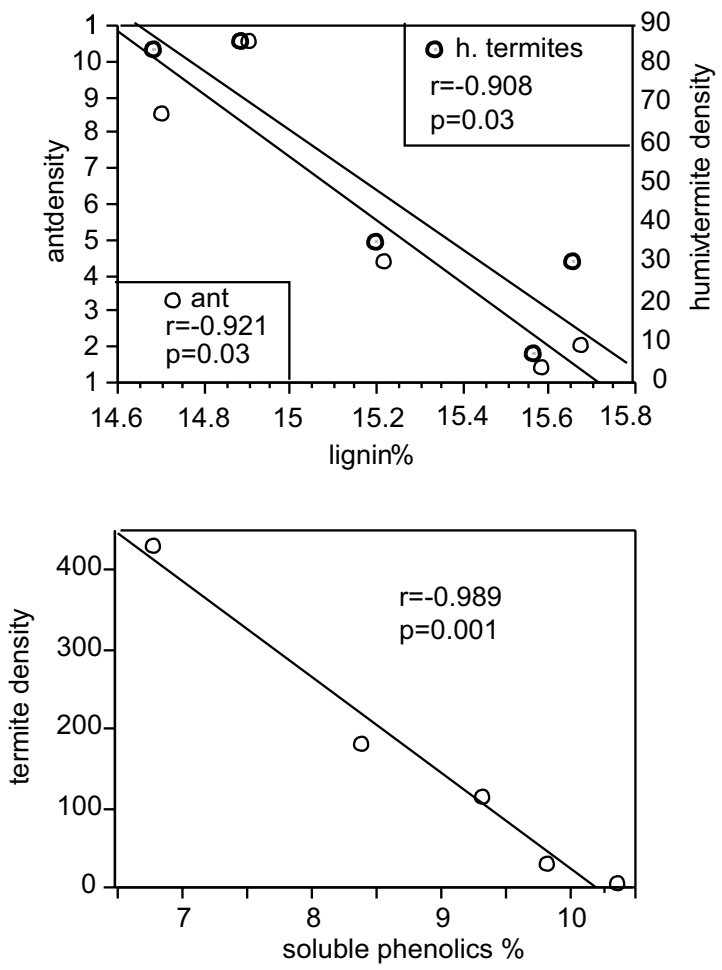

\section{Conclusions}

According to Heal and Dighton (1985), the combined effect of resource quality and physical environment selects microflora and the associated fauna. Consequently, the quality of primary producers could have more importance than their biodiversity, regarding the improvement of soil organic and biological status. Thus acacia plantations, with their low level of plant species richness, had the highest soil organic matter content and litter input (Bernhard-Reversat 1993), and the higher biomass of macrofauna. Vohland and Schroth (1999) studying an agroforestry 
system in Brazil, observed a greater density of macrofauna in a tree monoculture of peach palm than in a tree polyculture including peach palm, because this tree had a better litter quality. In the Congolese plantations which are grown on a very poor sandy soil, the increase of organic matter resource could be of tremendous importance in changing savanna habitat to forest habitat, not only regarding energy but also nutrient resource and biochemical quality (Mboukou-Kimbatsa et al. 1998). Although eucalypt plantations exhibit lower density and biodiversity than other tree species, they are able to improve degraded soil fertility by enhancing macrofauna populations as they do for mesofauna (Day et al. 1999).

Some trends were assessed through the 1996 and 1999 studies gathering 11 eucalypt plots in the Pointe-Noire plantations. Soil macrofauna spread out in plantations, together with aging and soil change, at different rates according to the planted tree species. Forest exploitation had little impact on these changes. 


\title{
Conclusions
}

\section{Soil Biological Fertility Undergoes Fundamental Changes When Fast-growing Exotic Trees Are Planted on a Poor Savanna Soil}

\author{
F. Bernhard-Reversat ${ }^{1}$ and C. Huttel ${ }^{2}$
}

$\mathrm{T}$ he changing environment from savanna to artificial forests was investigated with a multidisciplinary approach including vegetation, soil and soil organisms, to understand the main relationships between plant diversity, management practices and the biological factors of fertility (Fig. 8.1).

\section{Plantations Improve Biodiversity}

An original vegetation, rich in pioneer species, developed under plantations. Although secondary forest patches occurred among the plantations and could act as a seed source, the floristic composition of the undergrowth was very different from that observed in a nearby forest: most species present in the forest were not found in the plantations, and most species in the plantation undergrowth were absent from the forest plot. The plantations studied were grown on savannas which are not colonised by forest species because annual fires destroy the forest tree seedlings, and where natural evolution from grassland to forest seems not to be possible, unlike the situation described in unburnt Congolese savannas (de Foresta 1990). Commercial tree plantations in a very poor savanna environment bring drastic changes in environmental conditions, due to the reduction of fire occurrence and to the change toward forest microclimate and forest soil. These changes allow plant diversity increase in understorey vegetation, as observed elsewhere in afforested degraded lands such as mined sites or abandoned pastures (Lugo 1997; Parrotta et al. 1997; Powers et al. 1997), although Parrotta and Knowles (1999) showed that changes were faster when native species were planted instead of exotic species. In unlogged eucalypt plantations, the general trends with plantation age were an increase of species number, forest species percentage, woody cover density, height and basal area. In managed commercial plantations, the species richness was higher, mainly due to the abundance of savanna and ruderal species, and height and basal area were lower. Further studies should examine the role of the natural forest and the conditions for seed dissemination, germination and seedling growth in plantations' undergrowth. Some results, especially the relationships between soil $\mathrm{C}$, soil $\mathrm{pH}$, and either the number of undergrowth species or the percentage of forest species, suggested that the changing soil environment through organic matter accumulation could promote the establishment of the undergrowth.

This biodiversity, unwanted by foresters, could improve soil functioning by increasing the diversity of organic sources for soil biota and by decreasing the negative effect of eucalypt litter

\footnotetext{
1 Laboratoire d'Ecologie des Sols Tropicaux, Centre IRD d'Ile de France, 32 avenue Henri Varagnat, 93143 Bondy, France.

2 Le Caillou, Valojoux, 24290 Montignac, France.
} 
Figure 8.1 Relationships between the biological processes of fertility in eucalypt plantations in Congo

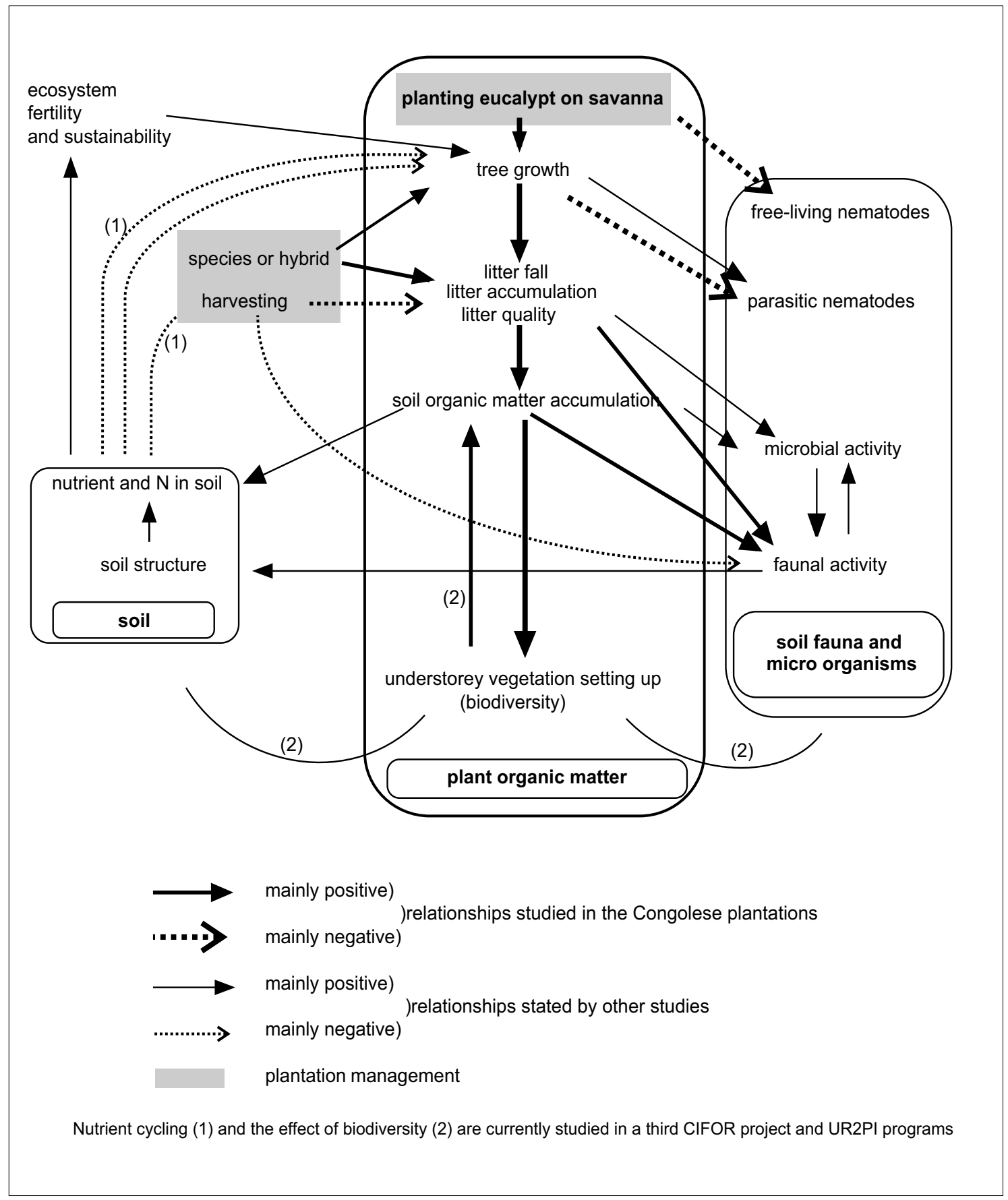


biochemicals such as polyphenols and terpenes, although undergrowth vegetation competes for water and nutrients with the tree crops (Dembi 1988). Microclimate, litter quantities and tree litter physical and chemical quality were assumed to control the abundance and nature of soil biota, and differed according to the planted species. The hypothesis of modified litter influence beneath undergrowth patches on soil biological processes will be studied during further investigations.

\section{Plantations Improve Soil Organic Matter Status and Biological Activity}

The present results suggest that litter accumulation and quality, and the resulting soil organic matter accumulation and quality, were among the main ecological changes when savanna was planted with trees, and determined the development of undergrowth and changes in soil characteristics (Wardle and Lavelle 1997). The fact that soil fauna was mostly correlated with percentage of forest or savanna species, rather than with the density of understorey plants, and the fact that changes in vegetation and fauna occurred after 7-10 years when soil organic matter content began to increase, suggested that both fauna and understorey vegetation were mainly affected by the type of habitat. Heal and Dighton (1985) observed that the increasing importance of fauna and the increasing dominance of macrofauna were related to the improvement of the quality of primary production residues. The great differences in litter quantity and quality occurring between eucalypt, acacia and pine resulted in major differences in soil microfauna and macrofauna density and biomass, and suggested that litter quality of the tree crop took precedence over plant biodiversity in controlling soil biota. In eucalypt plantations, the trend of fauna distribution to be associated with variations in eucalypt litter quality also supports this conclusion.

Lavelle (1996) suggests three mechanisms linking biodiversity and soil biological processes: the first implies plant diversity as the origin of soil fauna diversity (nested biodiversity), the second implies soil structure as mediator between biodiversity and functioning, and the third implies organic matter level and quality for changes in energy resources. In the plantations studied, organic matter resource could be of tremendous importance in changing savanna environment to forest environment, not only regarding energy resource availability but also nutrient resource and biochemical quality.

Improved soil processes were observed with the aging of eucalypt plantations due to changes in the soil-litter system: increased decomposition rates together with increased litterfall in aging plantations is assumed to enhance nutrient cycling. Increased soil organic matter with plot age enhanced cation exchange capacity and was therefore expected to improve the retention of nutrient imputs from rainfall, litter and fertilisers. An increase in soil organic matter is also assumed to be responsible for changes in macrofauna, and an improved soil functioning is expected from the increasing density of earthworm, termites and litter fauna (Lavelle 1994; Altieri 1999), related mainly to a faster organic matter turnover and improved soil structure.

\section{Assessment of the Adverse Effect of Plantations}

Among fast-growing trees, eucalypt is the only one grown commercially on large areas in the Congo and consequently their adverse effects on the environment must be managed.

Strong evidence for disturbance of microbial processes in eucalypt plantations is indicated by the absence of $\mathrm{N}$ fixation (chapter 4), nitrification (Bernhard-Reversat 1996), and white rot fungi (Bernhard-Reversat and Schwartz 1997). Although the lack of nitrification reduces nitrogen leaching, the decreasing nitrogen content of soil organic matter with plot age leads to mineral nitrogen deficiencies for tree growth, requiring fertiliser use by the second rotation, and this is one of the main problems foresters have to address. The introduction of a nitrogen-fixing understorey crop could greatly improve litter quality and soil organic matter content, but could also increase the level of tree infestation by plant parasitic nematodes.

Eucalypts are often regarded as damaging for the environment (Poore and Fries 1985) because of their allelopathic effects, which was shown in experimental conditions for the Congolese 
plantations (Bernhard-Reversat 1999) and numerous authors in other countries (e.g. Lisanework and Michelsen 1993; Souto et al. 1995; Reigosa et al. 1999). Concerning undergrowth biodiversity, eucalypts depressed forest species more than pine or acacia plantations, and the question arises if it is due either to allelopathy or to environmental conditions. Light intensity is often put forward as an alternative cause, but observations showed a lower canopy density under eucalypt than under the other planted species (Loumeto, unpublished results), which should result in a higher light intensity in eucalypt stands and favour pioneer species. The decrease in soil humidity due to eucalypt is also pointed out, but although comparison with savanna showed a depletion of soil humidity under eucalypt below $1 \mathrm{~m}$, no data are available for comparison with other tree species (Nizinski et al., in press). Dembi (1988) showed that in a young eucalypt plantation the adventitious vegetation competed efficiently for water, but in older plantations it might be stressed by water shortage. Nevertheless the need for weeding and the abundance of undergrowth in the field after 10-years of eucalypt cropping demonstrated that some plant species were able to avoid the adverse effect of eucalypts on plant growth.

The increasing density of the eucalypt parasitic nematodes Xiphinema parasetariae with the aging of plantations suggested that continuous eucalypt cultivation should result in an entirely infested area, and the effect of some practices, such as tree spacing or stump killing, on population decrease should be assessed. The effect of nematodes on tree growth is still unknown and should be studied together with the evaluation of the susceptibility of hybrids and its relationship with easily measurable parameters. Eucalypt plantations seem to be safe for eventual further cropping: Xiphinema parasetariae does not affect most local crops (cassava, groundnut, vegetable crops) which could replace the plantations, and the nematodes which are highly noxious for many food crops (mainly Meloidogyne spp.), do not develop on eucalypt roots.

The present practices of exploitation of eucalypt did not affect biological soil fertility factors, although the floristic composition of undergrowth and its abundance were changed. These practices kept the existing litter and residues on the ground, and even though the temporary increase of litter after exploitation does not last more than one year (Nzila, personal communication), it balances the low litterfall in the young regrowth. Consequently, although the litter system was affected by exploitation, soil organic matter was not obviously affected, and the biological activity in litter and soil was preserved. Silvicultural practices which improve the conservation of plant residue on the ground, besides being recommended to prevent nutrient export (O'Connell and Sankaran 1997), will enhance soil fauna density and consequently soil fertility (Altieri 1999).

\section{Conclusions}

The debate on growing block plantations of exotic trees is not closed and more factors must be taken into account than those studied here. The replacement by plantations of biological diverse ecosystems like rain forests are rightly questioned. In the case of harsh environment like the Congolese savanna, silviculture is a land use that has numerous positive effects although there are many problems still to be addressed.

The increase in soil organic matter which accounts for many positive changes is however a fragile process. All management practices likely to decrease inputs, such as the burning of harvest residues, the harvest of twigs and leaves for fuel, and the harvest of logs with the bark, are expected to counteract environmental improvement resulting from eucalypt growth (Brown et al. 1997). The choice of species and hybrids, beside their growth and wood qualities, should take into account litter quality and decomposition rate. Further research is needed on the cummulative effect of silvicultural practices involved in shortrotation forestry and its relation with soil organic matter.

This interdisciplinary work emphasised positive trends in eucalypt and other fast-growing plantations in relation to plant diversity and biological soil fertility. The knowledge generated by this study suggests changes in cultural practices which could have potential for more sustainable production in the long-term. 


\section{References}

Abbasi, S.A. and Vinithan, S. 1997. Ecological impacts of eucalypts - myths and realities. Indian Forester 123: 710-739.

Abbasi, S.A. and Vinithan, S. 1999. Ecological impacts of Eucalyptus tereticornis-globulus (Eucalyptus hybrid) plantation on a mining area. Indian Forester 125: 163-186.

Abbott, I., Wills, A. and Burbidge, T. 1999. The impact of canopy development on arthropod faunas in recently established Eucalyptus globulus plantations in Western Australia. Forest Ecology and Management 121: 147158.

Abelho, M. and Graça, M.A.S. 1996. Effect of eucalyptus afforestation on leaf litter dynamics and macro invertebrate community structure of stream in Central Portugal. Hydrobiologia 324: 195-204.

Aggangan, R.T., O'Connell, A.M., McGrath, J.F. and Dell, B. 1999. The effect of Eucalyptus globulus leaf litter on $\mathrm{C}$ and $\mathrm{N}$ mineralization in soil from pasture and native forest. Soil Biology and Biochemistry 31: 1481-1487.

Altieri, M. 1999. The ecological role of biodiversity in agroecosystems. Agriculture, Ecosystems and Environment 74: 19-31.

Anderson, J.M. and Ingram, J.S.I. 1993. Tropical soil biology and fertility. A handbook of methods. C.A.B. International, Oxford, England. 221p.

Anderson, J.M. and Swift M.J. 1983. Decomposition in tropical forests. In: Sutton S.L., Whitmore T.C. and Chadwick A.C. (eds.) Tropical rain forest: ecology and management, 287-309. Special publication 2, British Ecological Society. Blackwell Scientific, Oxford, England.

Anonymous. 1994. Model DR/700 portable colorimeter instrument manual. $\mathrm{HACH}$ Company, Loveland. 69.7-69.12.

Armstrong, A. and van Hensbergen, H.J. 1996. Impact of afforestation with pine on assemblages of native biota in South Africa. Suid-Afrikaan Bosbourydskrif 175: 35-42.

Arunachalam, A., Pandeu H.N., Tripathi, R.S. and Maithani, K. 1996. Fine root decomposition and nutrient mineralization patterns in a subtropical humid forest following tree cutting. Forest Ecology and Management 86: 141-150.

Attiwill, P.M., Polglase, P.J., Weston, P.J. and Adams, M.A. 1996. Nutrient cycling in forests of south-eastern Australia. In: Attiwill P.M. and Adams M.A. (eds.) Nutrition of eucalypts, 191227. CSIRO Publishing, Collingwood, Australia. 
Aweto, O.A. 1995. Organic carbon diminution and estimates of carbon dioxide release from plantation soil. The Environmentalist 15: 1015.

Baker, T.G. and Attiwill, P.M. 1985. Above ground nutrient distribution and cycling in Pinus radiata D. Don and Eucalyptus obliqua L'Herit. forests in southeastern Australia. Forest Ecology and Management 13: 41-52.

Balesdent, J., Pétraud, J.P. and Feller, C. 1991. Effets des ultrasons sur la distribution granulométrique des matière organiques des sols. Sciences du Sol 29: 95-105.

Bargali, S.S., Singh, S.P. and Singh, R.P. 1992. Structure and function of an age series of eucalypt plantations in Central Himalaya. II Nutrient dynamics. Annals of Botany 69: 413421.

Bargali, S.S., Singh, S.P. and Singh, R.P. 1993 Pattern of weight loss and nutrient release from decomposing leaf litter in an age series of eucalypt plantation. Soil Biology and Biochemistry 25: 1731-1738.

Basanta M., Vizcaino D.E., Casal, M. and Morey, M. 1989. Diversity measurements in shrubland communities of Galicia (NW Spain). Vegetatio 82: 105-112.

Baujard, P., Luc, M. and Reversat, G. 1998. Description of Xiphinema souchaudi $\mathrm{n}$. sp. and observations on $X$. yapoense Luc, 1958 and $X$. algeriense Luc and Kostadinov, 1982 (Nematoda: Longidoridae). Fundamental and Applied Nematology 21: 637-644.

Bernhard-Reversat, F. 1987. Les cycles des éléments minéraux dans un peuplement à Acacia seyal et leur modification en plantation d'Eucalyptus au Sénégal. Acta Oecologica, Oecologia Generalis 8: 3-16.

Bernhard-Reversat F. 1988. Soil nitrogen mineralization under a Eucalyptus plantation and a natural Acacia forest in Senegal. Forest Ecology Management 23: 233-244.
Bernhard-Reversat, F. 1991. Evolution of the soil litter interface under Eucalyptus plantation on sandy soil in Congo. Acta Oecologia 12: 825828.

Bernhard-Reversat, F. 1993. Dynamics of litter and organic matter at the soil-litter interface in fast-growing tree plantations on sandy ferralitic soils (Congo). Acta Oecologia 14: 179-195.

Bernhard-Reversat, F. 1996. Nitrogen cycling in tree plantations grown on poor savanna soil in Congo. Applied Soil Ecology 4: 161-172.

Bernhard-Reversat F. 1998. Change in $\mathrm{CO}_{2}$ release relationships with initial litter quality during early laboratory decomposition of tropical leaf litters. European Journal of Soil Biology 34: 117-122.

Bernhard-Reversat, F. 1999. The leaching of Eucalyptus hybrids and Acacia auriculiformis leaf litter: laboratory experiments on early decomposition and ecological implications in Congolese tree plantations. Applied Soil Ecology 12: 251-261.

Bernhard-Reversat, F. and Loumeto, J.J. In press. The litter system in African forest-tree plantations. In: Reddy, W. (ed.) Tropical plantation-forest management and the soil litter system: litter, biota and soil nutrient dynamics. Oxford and IBH Publications, New Delhi.

Bernhard-Reversat, F. and Schwartz, D. 1997. Change in lignin content during litter decomposition in tropical forests soils (Congo): comparison of exotic plantations and native stands. C.R. Academie des Sciences, Paris, Sciences de la Terre et des Planetes 325: 427432.

Bernhard-Reversat, F., Diangana, D. and Tsatsa, M. 1993. Biomasse, minéralomasse et productivité en plantation d'Acacia mangium et $A$. auriculiformis au Congo. Bois et Forêts des Tropiques No. 238: 35-44.

Binkley, D. 1997. Bioassays of the influence of Eucalyptus saligna and Albizia falcataria on soil nutrient supply and limitation. Forest Ecology and Management 91: 229-234. 
Binkley, D. and Resh, S.C. 1999. Rapid changes in soils following Eucalyptus afforestation in Hawaii. Soil Science Society of American Journal 63: 222-225.

Boissezon, (de) P. 1967. Etude pédologique de la vallée du Niari. In: Quinze ans de travaux et de recherches dans les pays du Niari. Tome 3 . Les sols de la vallée du Niari: études pédologiques et agro-pédologiques, 9-48. ORSTOM, Paris.

Bond, W.J. and Stock, W.D. 1990. Preliminary assessment of the grading of eucalyptus clones using carbon isotope discrimination. South African Forestry Journal 154: 51-55.

Bouillet, J.P., Nizinski, G., Nzila, J.D. and Ranger, J. 1997. The sustainability of Eucalyptus commercial plantations: the Congolese approach. In: Proceedings of IUFRO meeting Silviculture and Genetic Improvement of Eucalyptus, Salvador, Bahia, Brazil, August 1997. Vol. 4: Environmental and social impacts of eucalypt plantations, 232-237. EMBRAPA, Colombo, Brazil.

Bouillet, J.P., Nzila, J.D., Laclau, J.P. and Ranger, J. 2000. Effects of site management on Eucalyptus plantations in the Equatorial Zone, on the coastal plains of the Congo. In: Nambiar, E.K.S., Tiarks, A., Cossalter, C. and Ranger, J. (eds.) Site management and productivity in tropical plantation forests: a progress report: Workshop proceedings 7-11 December 1999, Kerala, India, 12-20. CIFOR, Bogor, Indonesia.

Bouvet, J.M. 1998. Les plantations d'Eucalyptus. Evolutions récentes et perspectives. Internal Note. CIRAD-Forêt, Montpellier, France. 35p.

Bouvet, J.M. 1999. Les plantations d'Eucalyptus. Evolutions récentes et perspectives. Le Flamboyant 49: 4-14.

Brent, E., Binkley, D. and Bashkin, M. 1996. Influence of adjacent stand on spatial pattern of soil carbon and nitrogen in Eucalyptus and Albizia plantations. Canadian Journal of Forestry Research 26: 1501-1503.
Brosset, A. 1966. Contribution à la faune du Congo (Brazzaville). Mission A. Villiers et A. Descarpentries. XX Chiroptères. Bulletin de l' Institut Fondanental d' Afrique Noire 28 (A): 362-369.

Brosset, A. 1990. A long term study of the rain forest birds in Mpassa (Gabon). In: Keast, A. (ed.) Biogeography and ecology of forest bird communities, 259-274. SPB Academic Publishers bv, The Hague.

Brosset, A.1997. Peuplements en oiseaux des plantations d'Eucalyptus dans la région de Pointe-Noire, Congo. Revue d' Ecolologie 52: 133-151.

Brosset, A. and Erard, C. 1986. Les oiseaux des régions forestières du nord-est du Gabon. Vol. 1: Ecologie et comportement des espèces. SNPN, Paris. 289p.

Brown, A.G., Nambiar, E.K.S. and Cossalter, C. 1997. Plantations for the tropics - their role, extent and nature. In: Nambiar E.K.S. and Brown A.G. (eds.) Management of soil, nutrients and water in tropical plantation forests, 3-23. ACIAR Monograph No. 43. ACIAR, Canberra.

Calder, I.R., Hall, R.L. and Adlard, P.G. (eds.) 1992. Growth and water use of forest plantations. Wiley and Sons, New York. 381p.

Chunyang, L. 1999. Carbon isotope composition, water-use efficiency and biomass productivity of Eucalyptus microtheca under different water supplies. Plant and Soil 214: 165-171.

Conde, E., Cadahaia, E. and Garcia-Vallejo, M.C. 1997. Low molecular weight polyphenols in leaves of Eucalyptus camaldulensis, E. globulus and E. rudis. Phytochemical Analysis 8: 186-193.

Constantinides, M. and Fownes, J.H. 1994. Nitrogen mineralization from leaves and litter from tropical plants: relationship to nitrogen, lignin and soluble polyphenol concentrations. Soil Biology Biochemistry 26: 49-55. 
Cortez, N.R.D.S. 1996. Compartimentos e ciclos de nutrientes em plantações de Eucalyptus globulus Labill. ssp. globulus e Pinus pinaster Aiton. PhD Thesis in Agronomy, Lisboa.

Crews, T.E., Farrington, H. and Vitousek, P.M. 2000. Changes in asymbiotic, heterotrophic nitrogen fixation on leaf litter of Metrosideros polymorpha with long-term ecosystem development in Hawaii. Ecosystems 3: 386395 .

Dambrine, E., Vega, J.A., Taboada, T., Rodriguez, L., Fernandez, C., Macias, F. and Gras, J.C. 2000. Bilans d'éléments minéraux dans de petits bassins versants forestiers de Galice (NW Espagne). Annals of Forest Science 57: 23-38.

Dangerfield, J.M. 1990. Abundance, biomass and diversity of soil macrofauna in savanna woodland and associated managed habitat. Pedobiologia 34: 141-150.

Day, C., Majer, J. and Mattiessen, J.N. 1999. Leaf litter invertebrates in the Western Australian wheatbelt: recolonisation of revegetation and its implications in restoring ecosystem functions and biodiversity. In: Proceedings of the $7^{\text {th }}$ Australian Conference on Grassland Invertebrate Ecology, 184-194. CSIRO Entomology, CSIRO Centre for Mediterranean Agricultural Research, Wembley.

Delwaulle, J.C. 1989. Plantations clonales au Congo. Point des recherches sur le choix des clones dix ans après les premières plantations. In: Gibson, G.L., Griffin, A.R. and Matheson, A.C. (eds.) Breeding tropical trees. Proceedings IUFRO Conference, Pattaya, Thailand, November 1988, 431-434. Oxford Forestry Institute, Oxford.

Delwaulle, J.C. and Laplace, Y. 1988. La culture industrielle de l'Eucalyptus en République Populaire du Congo. Bois et Forêts des Tropiques no. 216: 35-42.

Dembi, F. 1988. Effet de l'élimination de la végétation concurente sur l'humidité du sol et sur la croissance initiale d'une plantation monoclonale d'Eucalyptus 12 ABL x saligna
(Clone L2-109). Mémoire d'étude IDR, Université de Brazzaville. (unpublished).

Dowsett-Lemaire, F. and Dowsett, R.J. 1991. The avifauna of the Kouilou bassin in Congo. In: Dowsett-Lemaire, F. and Dowsett, R.J. (eds.) Flore et faune du Kouilou et leur exploitation, 189-239. Touraco Research Report 4. Touraco, Liège.

Duncan, R.S. and Chapman, C.A. 1999. Seed dispersal and potential forest succession in abandoned agriculture in Africa. Ecological Applications 9: 998-1007.

Dye, P.J. 1996. Climate, forest and streamflow relationships in South African afforested catchments. Commonwealth Forestry Review 75: 31-38.

Ellis, R.C. 1971. The mobilisation of iron by extracts of Eucalyptus leaf litter. Journal of Soil Sciences 22: 8-22.

Enright, N.J. 1978. The interrelationship between plant species distribution and properties of soils undergoing podzolization in a coastal area of S.W. Australia. Australian Journal of Ecology 3: 389-401.

Fargette, M. 1987. Use of esterase phenotype in the taxonomy of genus Meloïdogyne. 2. Esterase phenotype observed in west African populations and their characterisation. Revue de Nématologie 10: 45-56.

Feller, C., Fritsch, E., Poss, R. and Valentin, C. 1991. Effet de la texture sur le stockage et la dynamique des matières organiques dans quelques sols ferrugineux et ferralitiques (Afrique de l'Ouest en particulier). Cahiers ORSTOM, serie Pedologie 26: 25-36.

Ferris, H., Venette, R.C., van der Meulen, H.R. and Lau, S.S. 1998. Nitrogen mineralization by bacterial-feeding nematodes: verification and measurement. Plant and Soil 203: 159-171.

Food and Agriculture Organization (FAO). 1982. Les Eucalyptus dans les reboisements. Collection FAO Forêt. 753p. 
Foresta, (de), H., 1990. Origine et évolution des savanes intramayombiennes (R.P. du Congo). Apports de la botanique forestière. In: Lanfranchi, R. and Schwartz, D. (eds.) Paysages quaternaires de l'Afrique centrale, 326-335. ORSTOM, Paris.

Fox, R.H., Myers, R.J.K. and Vallis, I. 1990. The nitrogen mineralization rate of legume residues in soil as influenced by their polyphenol, lignin, and nitrogen contents. Plant and Soil 129: 251259.

Gbadegesin, R.A. 1993. Effect on the development of Pinus caribaea seedlings of certain plant parasitic nematodes from the savanna area of Nigeria. Forest Ecology and Management 60: 163-166.

Geldenhuys, C.J. 1997. Native forest regeneration in pine and eucalypt plantations in Northern Province, South Africa. Forest Ecology and Management 99: 101-116.

Gibson, A.H., Halsall, D.M. and Roper, M.M. 1988. Nitrogen fixation associated with residues breakdown. In: Bothe, H., de Bruijn, F.J., Newton, W.E. (eds.) Nitrogen fixation: hundred years after, 753-758. Gustav Fischer Verlag, Stuttgart, Germany.

Gilot, C., Lavelle, P., Blanchard, E., Keli, J., Kouassi, P., Guillaume, G. 1995. Biological activity of soil under rubber plantations in Côte d'Ivoire. Acta Zoologica Fennica 196: 186189.

Goede (de), R.G.M., Georgieva, S.S., Verschoor, B.C. and Kamerman, J.W. 1993. Changes in nematode community structure in a primary succession of blown-out areas in a drift sand landscape. Fundamental and Applied Nematology 16: 501-513.

Gonçalves, J.L.M., Barros, N.F., Nambiar, E.K.S. and Novals, R.F. 1997. Soil and stand management for short-rotation plantations. In: Nambiar, E.K.S. and Brown, A.G. (eds.) Management of soil, nutrients and water in tropical plantation forests, 379- 418. ACIAR Monograph 43. ACIAR, Canberra.
Gonçalves, J.L.M., Poggiani, F. and Stape, J.L. 1999. Eucalypt plantations in the humid Tropics: São Paulo, Brazil. In: Nambiar, E.K.S., Cossalter, C. and Tiarks, A. (eds.) Site management and productivity in tropical plantation forests: workshop proceedings, 1620 February 1998, Pietermaritzburg, South Africa, 5-12. CIFOR, Bogor, Indonesia.

Gonzales, G. and Seastedt, T.R. 2000. Comparison of the abundance and composition of litter fauna in tropical and subalpine forests. Pedobiologia 44: 545-555.

Granhall, U. 1978. Environmental role of $\mathrm{N}_{2}-$ fixing blue-green algae and asymbiotic bacteria. Ecological Bulletin no. 26. 391p.

Groethals, M. 1987. Répartition et pante hôte des nématodes à galles (Meloidogyne spp.) au Burundi. In: Séminaire sur les ravageurs des principales cultures vivrières d'Afrique centrale, Bujumbura, 16-20 février 1987, 367375. CTA, Wageningen, The Netherlands.

Grove, T.S., Thomson, B.D. and Malajczuk, N., 1996. Nutritional physiology of eucalypts: uptake, distribution and utilization. In : Attiwill, P.M. and Adams, M.A. (eds.) Nutrition of eucalypts, 77-108. CSIRO Publishing, Collingwood, Australia.

Harborne, J.B. 1997. Role of phenolic secondary metabolites in plants and their degradation in nature. In: Cadisch, G. and Giller, K.E. (eds.) Driven by nature: plant litter quality and decomposition, 67-74. CAB International, Oxford.

Hardy, R.W.F., Holsten, R.D., Jackson, E.K. and Burns, R.C. 1968. The acetylene-ethylene assay for $\mathrm{N}_{2}$ fixation : laboratory and field evaluation. Plant Physiology 43: 1185-1207.

Harmand, J.M. 1998. Rôle des espèces ligneuses à croissance rapide dans le fonctionnement biogéochimique de la jachère. Effets sur la restauration de la fertilité des sols ferrugineux tropicaux. (Bassin de la Bénoué au Nord Cameroun). Thesis in tropical plant biology and ecology. Université Paris. 
Harrington, R.A. and Ewel, J.J. 1997. Invasibility of tree plantations by native and nonindigenous plant species in Hawaii. Forest Ecology and Management 99: 153-162.

Heal, O.W. and Dighton, J. 1985. Resource quality and trophic structure in the soil system. In: Fitter, A.H., Atkinson, D., Read, D.J. and Usher, M.B. (eds.) Ecological interaction in soil, 339-354. Blackwell Scientific, Oxford, England.

Herbert, M.A. 1996. Fertilizers and eucalypt plantations in South Africa. In: Attiwill, P.M. and Adams, M.A. (eds.) Nutrition of eucalypts, 303-325. CSIRO Publishing, Collingwood, Australia.

International Foundation for Science (IFS). 1989. Proceedings of a regional seminar on trees for development in sub-Saharan Africa, Nairobi (Kenya). Nairobi, Kenya. 361p.

Jaiyeoba, I.A. 1998. Change in soil properties related to conversion of savannah woodland into pine and eucalyptus plantations, Northern Nigeria. Land Degradation and Development 9: 207-215.

Jamet, R. 1975. Evolution des principales caractéristiques des sols des reboisements de Pointe-Noire. Orstom, Cote MC 189, Centre de Brazzaville, décembre 1975. 35p. (unpublished).

Kallarackal, J. and Somen, C.K. 1997. An ecophysiological evaluation of the suitability of Eucalyptus grandis for planting in the tropics. Forest Ecology and Management 95: 53-61.

Keenan, R., Lamb, D., Woldring, O., Irvine, A. and Jensen, R. 1997. Restoration of plant diversity beneath tropical tree plantations in northern Australia. Forest Ecology and Managment 99: 117-132.

King, J.A. and Campbell, B.M. 1994. Soil organic matter relations in five land cover types in the miombo region (Zimbabwe). Forest Ecology and Management 67: 225-239.
Kirkpatrick, J.B. 1997. Vascular plant-eucalypt interactions. In: Williams J.E. and Woinarski J.C.Z. (eds.) Eucalypt ecology: individuals to ecosystems, 227-245. Cambridge University Press, Cambridge, England.

Knockaert, C. 1981. Production de littiere dans quatre plantations d'Eucalyptus camaldulensis et dans un peuplement naturel de Quercus suber. Annales de la Recheche Forestière au Maroc 21: 351-373.

Knowles, R., Brouzes, R. and O'Toole, P. 1973. Kinetics of nitrogen fixation and acethylene reduction, and effects of oxygen and of acethylene on these processes, in a soil system. Bulletin of Ecological Research Communications 17: 255-262.

Laclau, J.P., Bouillet, J.P. and Ranger, J. 2000a Dynamics of biomass and nutrient accumulation in a clonal plantation of Eucalyptus in Congo. Forest Ecology and Management 128: 181-196.

Laclau, J.P., Bouillet, J.P. and Ranger, J. 2000b. Canopy and soil modification of precipitation chemistry in a clonal eucalypt plantation in the Congo. Comparison with an adjacent savanna ecosystem. Proceedings of the XXI IUFRO World Congress, Kuala Lumpur, Malaysia.

Laclau, J.P., Ranger, J., Nzila, J.D. and Bouillet, J.P. 2000c. Nutrient cycling in a short rotation Eucalyptus plantation and adjacent savanna in Congo. In: Nambiar, E.K.S., Tiarks, A., Cossalter, C. and Ranger, J. (eds.) Site management and productivity in tropical plantation forests: a progress report: Workshop proceedings 7-11 December 1999, Kerala, India, 95-99. CIFOR, Bogor, Indonesia.

Lamb, D. 1998. Large scale ecological restoration of degraded tropical forest lands: the potential role of timber plantations. Restoration Ecology 6: 271-279.

Lamotte, M. 1979. Secondary production: consumption and decomposition. In: Tropical grazing land ecosystems, 146-208. UNESCO Natural Resource Research 16. UNESCO. 
Lavelle P. 1996. Diversity of soil fauna and ecosystem function. Biology International 33: 3-16.

Lavelle, P., Bignell, D., Lepage, M., Wolters, V., Roger, P., Ineson, P., Heal, O.W. and Dhillion, S. 1997. Soil function in a changing world: the role of invertebrate ecosystem engineers. European Journal of Soil Biology 33: 159-193.

Lavelle, P., Dangerfield, M., Fragoso, C., Eschenbrenner, V., Lopez-Hernandez, D., Pashani, B. and Brussaard, L. 1994. The relationship between soil fauna and tropical soil fertility. In: Woomer, P.L. and Swift, M.J. (eds.) The biological management of tropical soil fertility, 137-169. TSBF, Wiley, Chichester, England.

Lawton, J.H., Bignell D.E., Bolton, B., Bloemers G.F., Eggleton, P., Hammond, P.M., Hodda, M., Holt, R.D., Larsen, T.B., Mawdsley, N.A., Stork, N.E., Srivastava, D.S. and Watt, A.D. 1998. Biodiversity inventories, indicator taxa and effect of habitat modification in tropical forest. Nature 391: 72-76.

Lemieux, G. 1996. Le bois raméal et la pédogénèse: une influence agricole et forestière directe. Publication No.15, 2ième édition. http:/ /forestgeomat.for.ulaval/

Li, H. and Madden, J.L. 1995. Analysis of leaf oils from a Eucalyptus species trial. Biochemical Systematic and Ecology 23: 167177.

Lisanework, N. and Michelsen, A. 1993. Allelopathy in agroforestry systems: the effects of leaf extracts of Cupressus lusitanica and three Eucalyptus spp. on four Ethiopian crops. Agroforestry 21: 63-74.

Lopez-Fando, C. and Bello, A. 1995. Variability in soil nematode populations due to tillage and crop rotation in semi-arid Mediterranean agrosystems. Soil and Tillage Research 36: 5972 .

Loubana, P.M. 1996. Survey of nematodes of the genus Meloidogyne parasitic on crops in Congo. Nematropica 26: 287.
Loubelo, E. 1990. Etude comparative de quelques éléments du fonctionnement de deux peuplements d'Eucalyptus au Congo. Thesis, Université de Rennes.141p.

Loumeto, J.J. 1986. Contribution à l'étude de la distribution minérale dans les Eucalyptus du Congo. Thesis, Université de Rennes.

Loumeto, J.J. and Huttel, C. 1997. Understory vegetation in fast-growing tree plantations on savanna soils in Congo. Forest Ecology and Management 99: 65-81.

Luc, M. and Reversat, G. 1985. Possibilités et limites des solutions génétiqures aux affections provoquées par les nématodes sur les cultures tropicales. C.R. des Séances de l'Académie d'Agriculture de France 71: 781-791.

Lugo, A.E. 1997. The apparent paradox of reestablishing species richness on degraded lands with tree monocultures. Forest Ecology and Management 99: 9-19.

Lugo, A.E., Cuevas, E. and Sanchez, M.J. 1990. Nutrients and mass in litter and top soil of ten tropical tree plantations. Plant and Soil 125: 263-280.

Lugo, A.E., Parrotta, J. and Brown, S. 1993. Loss in species caused by tropical deforestation and their recovery through management. Ambio 22: 106-109.

Madeira, M.A.V., Andreux, F. and Portal, J.M. 1989. Changes in soil organic matter characteristics due to reforestation with Eucalyptus globulus in Portugal. The Science of the Total Environment 81/82: 481-488.

Maity, S.K. and Joy, V.C. 1999. Impact of antinutritional compounds of leaf litter on detritivore soil arthropod fauna. Journal of Ecobiology 11: 193-202.

Majer, J.D., Recher, H.F., Wellington, A.B., Woinarski, J.C.Z. and Yen, A.L. 1997. Invertebrates of eucalypt formations. In: Williams, J.E. and Woinarski, J.C.Z. (eds.) Eucalypt ecology: individuals to ecosystems, 278-302. Cambridge University Press, Cambridge, England. 
Marais, M. and Buckley, N.H. 1993. Plant parasitic nematodes in forest soils in the Transvaal and Natal, South Africa. South African Forestry Journal 166: 9-16.

Mboukou-Kimbatsa, I.M.C., Bernhard-Reversat, F. and Loumeto, J.J. 1998. Change in soil macrofauna and vegetation when fast growing trees are planted on savanna soils. Forest Ecology and Management 110: 1-12.

Michelsen, A., Lisanework, N., Friis, I. and Holst, N. 1996. Comparisons of understorey vegetation and soil fertility in plantations and adjacent natural forests in the Ethiopian highlands. Journal of Applied Ecology 33: 627642.

Miranda, G.A. de, Barros, N.F. de, Leite, H.G., Couto, L., Teixeira, J.L. de, -Miranda, G.A. de and Barros, N.F. 1998. Yield of eucalypt stands managed by coppicing, as influenced by fertilizing and slash disposal in the Jequitinhonha Valley, Minas Gerais, Brazil. Revista Arvore 22: 307-314.

Morais, E.J., Barros, N.F., Novais, R.F. and Brandi, R.M. 1990. Biomassa e eficiência nutricional de espécies de eucalipto em duas regioes bioclimaticas de Minas Gerais. Revista Brasileira de Ciência do Solo 14: 353-362.

Nandi, A., Basu, P.K. and Banerjee, S.K. 1991. Modification of some soil properties by Eucalyptus species. Indian Forester 117: 5357.

Negi, J.D.S. and Sharma, S.C. 1996. Mineral nutrition and resource conservation in Eucalyptus plantations and other forest covers in India. In: Attiwill, P.M. and Adams, M.A. (eds.) Nutrition of eucalypts, 399-416. CSIRO Publishing, Collingwood, Australia.

Nicholas, W.L. 1975. The biology of free-living nematodes. Clarendon Press, Oxford, England. 219 p.

Nizinski, J., Loumeto, J.J., Ayoma, M.-B., Mabiala-N'goma, A. and Nsemi, R.N. In press. Bilan d'eau du sol d'une savane et d'une plantation d'Eucalyptus dans le bassin du Kouilou (Congo). Science et Changements Planétaires - Sécheresse.

Nongamani, A. 1988. Dynamique de la végétation et des sols sous forêts d'Eucalyptus et de pins. Cas de Loudima. Mémoire de Diplome de l'Institut de Développement rural, Université de Brazzaville, 98p. (unpublished).

Nyathi, P., Campbell, B. and Maghembe, J.A. 1991. Leaf quality of Sesbania sesban, Leucaena leucocephala, and Brachystegia spiciformis: potential agroforestry species. Forest Ecology and Management 64: 259-264.

Nzila, J.D. 1992. Etude des transformations structurales et physico-chimiques d'un sol ferrallitique acide de la vallée du Niari (Congo) soumis à la pratique de l'écobuage. Thesis, University of Paris 12.

O'Connell, A.M. and Grove. T.S. 1987. Seasonal variation in $\mathrm{C}_{2} \mathrm{H}_{2}$ reduction ( $\mathrm{N}_{2}$-fixation) in the litter layer of eucalypt forests of south-western Australia. Soil Biology and Biochemistry 19: 135-142.

O'Connell, A.M. and Grove, T.S. 1996. Biomass production, nutrient uptake and nutrient cycling in the jarrah (Eucalyptus marginata) and karri (Eucalyptus diversicolor) forest of southwestern Australia. In:Attiwill, P.M. and Adams, M.A. (eds.) Nutrition of eucalypts, 155-190. CSIRO Publishing, Collingwood, Australia.

O'Connell, A.M. and Sankaran, K.V. 1997. Organic matter accretion, decomposition and mineralisation. In: Nambiar, E.K.S. and Brown, A.G. (eds.) Management of soil, nutrients and water in tropical plantation forests, 443-480. ACIAR Monograph No. 43. ACIAR, Canberra.

Palm, C.A. and Rowland, A.P. 1997. A minimum dataset for characterization of plant quality for decomposition. In: Cadisch, G. and Giller, K.E. (eds.) Driven by nature: plant litter quality and decomposition, 379-392. CAB International, Oxford, England. 
Pandey, D. 1997. Hardwood plantations in the tropics and subtropics. Tropical forest plantations area in 1995. CIFOR Occasional Paper. CIFOR, Bogor, Indonesia. 76p.

Paoletti, M.G. 1999. The role of earthworms for assessment of sustainability and as bioindicator. Agriculture, Ecosystems and Environment 74: 137-135.

Parrotta, J.A. 1993. Secondary forest regeneration on degraded tropical lands. The role of plantations as 'foster ecosystems'. In: Lieth, H. and Lohman, M. (eds.) Restoration of tropical forest ecosystem, 63-73. Kluwer Academic Publishers, Netherlands.

Parrotta, J.A. 1995a. Influence of overstory composition on understory colonisation by native species in plantations on degraded tropical site. Journal of Vegetation Science 6: 627-636.

Parrotta, J.A. 1995b. The catalytic effect of tree plantings on the rehabilitation of native forest biodiversity on degraded tropical lands: an exploratory analysis. Methodologies, field protocols and schedule. The World Bank, USDA Forest Service, IITF, ODA (UK), CIFOR. 20p (unpublished).

Parrotta, J.A. 1999. Productivity, nutrient cycling, and succession in a single - and mixed-species plantations of Casuarina equisetifolia, Eucalyptus robusta and Leucaena leucocephala in Puerto Rico. Forest Ecology and Management 124: 45-77.

Parrotta, J.A. and Knowles, O.H. 1999. Restoration of tropical moist forests on bauxitemined lands in the Brazilian Amazon. Restoration Ecology 7: 103-116.

Parrotta, J.A., Baker. D.D. and Fried, M. 1996. Changes in dinitrogen fixation in maturing stands of Casuarina equisetifolia and Leucaena leucocephala. Canadian Journal of Forest Research 26: 1684-1691.

Parrotta, J., Knowles, O.H. and Wunderle, J.M. jr. 1997. Development of floristic diversity in 10- year-old restoration forests on a bauxite mined site in Amazonia. Forest Ecology and Management 99: 21-42.

Parrotta, J.A., Turnbull, J.W. and Jones, N. 1997. Catalyzing native forest regeneration on degraded tropical lands. Forest Ecology and Management 99: 1-8.

Pendge, G. 1994. Fruit consumation and seed dispersal by the African civet Civectictis civetta in Mayombe, Zaïre. Revue d'Ecologie 49: 107116.

Petit, L.J., Petit, D.R., Christian, D.G. and Powell, H.D.W. 1999. Bird communities in natural and modified habitats in Panama. Ecography 22: 292-304.

Pohlman, A.A. and McColl, J.G. 1988. Soluble organics from forest litter and their role in metal dissolution. Soil Science Society of America Journal 52: 265-271.

Polglase, P.J. and Attiwill, P.M. 1992. Nitrogen and phophorus cycling in relation to stand age of Eucalyptus regnans F. Muell. I. Return from plant to soil in litterfall. Plant and Soil 142: 157-166.

Poore, M.E.D. and Fries, C. 1985. The ecological effect of Eucalyptus. F.A.O. Forestry Paper 59. FAO, Rome. 87p.

Porazinska, D.L., Duncan, L.W., McSorley, R. and Graham, J.H. 1999. Nematode communities as indicators of status and processes of a soil ecosystem inflenced by agricultural management practices. Applied Soil Ecology 13: 69-86.

Powers, J.S., Haggar, J.P. and Fisher, R.F. 1997. The effect of overstory composition on understory woody regeneration and species richness in 7-year-old plantations in Costa Rica. Forest Ecology and Management 99: 4354.

Pradhan, G.B., Senapati, B.K. and Dash, M.C. 1988. Relationship of soil nematode population to carbon/nitrogen in tropical 
habitat and their role in the laboratory decomposition of litter amendments. Revue d'Ecologie et de Biologie du Sol 25: 59-76.

Reigosa, M.J., Sanchez-Moreiras, A. and Gonzales, L. 1999. Ecophysiological approach in allelopathy. Critical Review in Plant Science 18: 577-608.

Reversat, G. 1981. Age related changes in the chemical oxygen demand of second stage juveniles of Meloidogyne javanica and Heterodera oryzae. Nematologica 27: 220-227.

Reversat, G. 1996. Anhydrobiosis in plant parasitic dorylaimids. Nematropica 26: 218 219.

Roger, P.A. and Ladha, J.K. 1992. Biological nitrogen fixation in wetland ricefields: estimation and contribution to nitrogen balance. Plant and Soil 141: 41-55.

Safou-Matondo, R., Laclau, J.P. and Bouillet, J.P. 1999. Etude de biomasse sur quatre clones d'Eucalyptus urophylla x Eucalyptus grandis: établissement de tarifs pour différents compartiments aériens et exploration de la variabilité inter-clonale. UR2PI report. $15 \mathrm{p}$. (unpublished).

Salter, P.J. 1996. The interaction of bird communities with vegetation in Brisbane forest Park. Emu 95: 194-207.

Sankaran, K.V. et al. 2000. Effects of site management on Eucalyptus plantations in the monsoonal tropics. In: Nambiar, E.K.S., Tiarks, A., Cossalter, C. and Ranger, J. (eds.) Site management and productivity in tropical plantation forests: a progress report: Workshop proceedings 7-11 December 1999, Kerala, India, 51-60. CIFOR, Bogor, Indonesia.

Schulze, E.D. and Mooney, H.A. 1993. Biodiversity and ecosystem function. Ecological Studies 99. Springer Verlag, Berlin. $525 \mathrm{p}$.

Scott, D.F. and Smith, R.E. 1997. Preliminary empirical models to predict reductions in total and low flows resulting from afforestation. Water South Africa 23: 135-140.
Seinhorst, J.W. 1950. De betekenis van de toestand van de grond voor het optreden van aantasting door het stengelaaltje (Ditylenchus dipsaci (Kühn) Filipjev). Tijdschrift over Plantenziekten 56: 289-348.

Seinhorst, J.W. 1955. Een eenvoudige methode voor het afschieden van aaltjes uit grond. Tijdschrift over Plantenziekten 61: 188-190.

Silva (da), M.C. Jr., Scarano, F.R. and Souza Cardel, F. 1995. Regeneration of an atlantic forest formation in the understory of a Eucalyptus grandis plantation in south-eastern Brazil. Journal of Tropical Ecology 11: 147152.

Smith, K.D. 1974. The utilization of gum-trees by birds in Africa. Ibis 116: 155-164.

Soler, C. 1994. Etude de la dynamique du recrû forestier en sous-bois d'eucalyptus. Université des Sciences Paul Sabatier/Orstom, Rapport de Maîtrise, Université de Toulouse. Unpublished report. 53p.

Souto, X.C., Gonzalez, L. and Reigosa, M.J. 1995. Allelopathy in forest environment in Galicia, NW Spain. Allelopathy Journal 2: 67-68.

Spaull,V.W. 1998. A note on the effect of using a nematicide on sugar cane planted in a sandy soil previously cropped to Eucalyptus trees. Proceedings of the Annual Congress of the South African Sugar Technology Association 72: 94-97.

Stewart, H.T.L. and Van der Lingen, S.A. 1988. Soil chemical properties under miombo woodland and eucalypt plantation on Kalahari sand in Zimbabwe. East African Agricultural and Forestry Journal 52: 171-179.

Tassin, J. and Rivière, J.N. 1998. Évaluation de l'impact des plantations forestières sur l'avifaune: application au littoral réunionais. Bois et Forêts des Tropiques No. 258: 37-47.

Tian, G. 1998. Effect of soil degradation on leaf decomposition and nutrient release under humid tropical conditions. Soil Science 163: 897-906. 
Trouvé, C., Mariotti, A., Schwartz, D. and Guillet, B. 1994. Soil organic carbon dynamics under Eucalyptus and Pinus planted on savannas in the Congo. Soil Biology Biochemistry 26: 287295.

Turner, J. and Lambert, M.J. 1983. Nutrient cycling within a 27-year-old Eucalyptus grandis plantation in New South Wales. Forest Ecology and Management 6: 155-168.

Turner, J. and Lambert, M.J. 1996. Nutrient cycling and forest management. In: Attiwill, P.M. and Adams, M.A. (eds.) Nutrition of eucalypts, 229-240. CSIRO Publishing, Collingwood, Australia.

Van Soest, P.J. 1963. Use of detergents in the analysis of fibrous feeds. II. A rapid method for the determination of fibre and lignin. Journal of the Assistant Officers in Agricultural Chemistry 46: 829-835.

Vohland, K. and Schroth, G. 1999. Distribution patterns of the litter macrofauna in agroforestry and monoculture plantations in central Amazonia as affected by plant species and management. Applied Soil Ecology 13: 57-68.

Wallace, H.R. 1973. Nematode ecology and plant disease. Edward Arnold, London. 228p.

Wardle, D. and Lavelle, P. 1997. Linkages between soil biota, plant litter quality and decomposition. In: Cadisch, G. and Giller, K.E. (eds.). Driven by nature: plant litter quality and decomposition, 107-125. CAB-International, Wallingford, England.

Waterman, P.G. and Mole, S. 1994. Analysis of phenolic plant metabolites. Methods in Ecology. Blackwell Scientific, London. 238p.

Wilson, J.V. and Wilson, B.L.P. 1991. La chasse traditionnelle et commerciale dans le sud ouest du Congo. In: Dowsett-Lemaire, F. and Dowsett, R.J. (eds.) Flore et faune du Kouilou et leur exploitation. Touraco Research Report 4: 279-289. Touraco, Liège.
Wilson, R.A., Astorga, R., Gomez, C. and Gonzalez-Rio, F. 1995. Papermaking with DNA. 'Intelligent Fibre'. In: Potts, B.M., Borralho, N.M.G., Reid, J.B., Cromer, R.N., Tibbitts, W.N. and Raymond, C.A. (eds.) Proceedings of the CRCTHF-IUFRO Conference: Eucalypt plantations: improving fibre yield and quality, 5-9. Cooperative Research Centre for Temperate Hardwood Forestry, Hobart, Australia.

Yeates, G.W. 1979. Soil nematodes in terrestrial ecosystems. Journal of Nematology 11: 213229.

Zou, X. 1993. Species effect on earthworm density in tropical tree plantations in Hawaii. Biology and Fertility of Soils 15: 35-38.

Zou, X. and Bashkin, M. 1998. Soil carbon accretion and earthworm recovery following revegetation in abandoned sugar cane fields. Soil Biology and Biochemistry 30: 825-830. 
7 he environmental impact of eucalypt plantations in particular on soil water and nutrients, 1 understorey vegetation and biodiversity is a controversial topic. Commercial plantations, mainly eucalypts, have been established on poor sandy soils of savannas in the Congo since 1978. This report on the role of biological factors in soil fertility complements studies of nutrient balance and logging residue management in progress in these plantations. Biotic processes in relation to plantation age and biotic changes in successive rotations were investigated. Changes of understorey vegetation with age, received special attention. Relationships between vegetation and soil fertility, which are closely linked to litter and soil organic matter quality and quantity; were studied in an age series of eucalypt hybrids and clones. The density of the main taxa of macrofauna and nematodes, which act through organic matter decomposition, soil biogenic structures and parasitism, was assessed according to plantation age and logging history. Nitrogen-fixation by soil organisms was also assessed. Soil organic matter accumulation and quality were among the main ecological changes found to occur when savanna was planted with trees, and determined the development of undergrowth and changes in soil characteristics. The differences in litter quantity and quality of eucalypt, acacia and pine plantations resulted in major differences in soil microfauna and macrofauna density and biomass, and suggested that litter quality of the tree crop took precedence over plant biodiversity in controlling soil biota. Short-rotation plantation forestry is a land use with numerous positive effects in the Congolese savanna environment, although more research is needed on longer-term effects of silvicultural practices on soil organic matter.
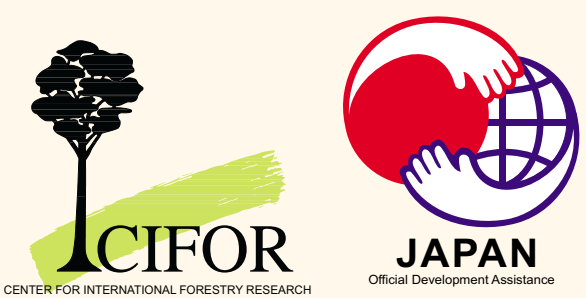